\title{
norden
}

\section{Age at retirement by educational background in Nordic countries}

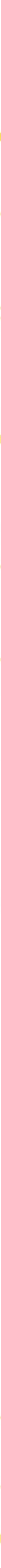



4 norden 



\section{Age at retirement by educational background in Nordic countries}

Statistics Sweden

TemaNord 2013:589 
Age at retirement by educational background in Nordic countries Statistics Sweden

ISBN 978-92-893-2666-7

http://dx.doi.org/10.6027/TN2013-589

TemaNord 2013:589

(C) Nordic Council of Ministers 2013

Layout: Hanne Lebech

Cover photo: ImageSelect

This publication has been published with financial support by the Nordic Council of Ministers. However, the contents of this publication do not necessarily reflect the views, policies or recommendations of the Nordic Council of Ministers.

\section{www.norden.org/en/publications}

\section{Nordic co-operation}

Nordic co-operation is one of the world's most extensive forms of regional collaboration, involving Denmark, Finland, Iceland, Norway, Sweden, and the Faroe Islands, Greenland, and Åland

Nordic co-operation has firm traditions in politics, the economy, and culture. It plays an important role in European and international collaboration, and aims at creating a strong Nordic community in a strong Europe.

Nordic co-operation seeks to safeguard Nordic and regional interests and principles in the global community. Common Nordic values help the region solidify its position as one of the world's most innovative and competitive.

\section{Nordic Council of Ministers}

Ved Stranden 18

DK-1061 Copenhagen $\mathrm{K}$

Phone (+45) 33960200

www.norden.org 


\section{Content}

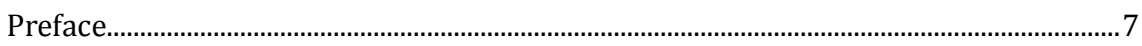

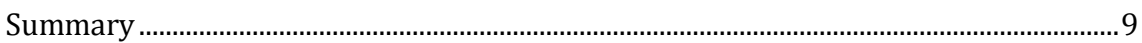

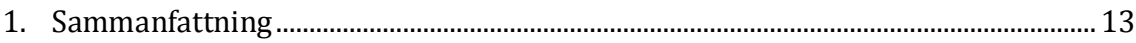

1.1 Employed persons in Nordic countries ......................................................... 15

1.2 Legislated pension systems and retirement ages........................................... 23

1.3 Average age at retirement - definition ……................................................... 25

1.4 Average age at retirement by level of education............................................. 27

1.5 Average age at retirement by fields of education, secondary level .............. 32

1.6 Average age at retirement by fields of education, post-secondary

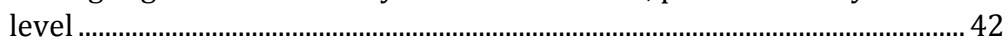

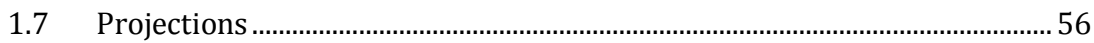

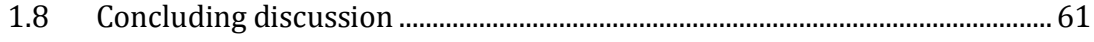

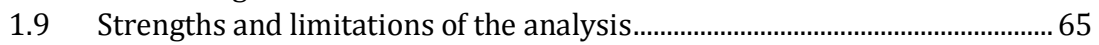

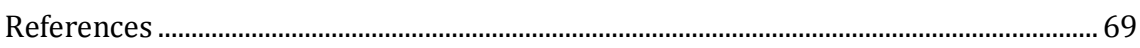

Appendix 1 - Data tables...................................................................................................... 71

Appendix 2 - ISCED Levels and Fields of education...................................................... 81 



\section{Preface}

The age structure of the labour force in the Nordic countries will change over the next few years. A majority of working persons age 50 and older will retire by 2020. The present report focuses specifically on the education dimension of this process, showing how retirement age varies by level and field of education. It is intended to serve as a background for ongoing discussions - in the Nordic as well as in many other countries regarding the ageing population and the sustainability of present day pension regimes.

The study was approved in March 2012 by the Labour Market Comittee of the Nordic Council of Ministers. Statistics Sweden, SCB, has led the project as a joint effort together with the national statistics agencies from Denmark, Finland, and Norway. The final report was delivered in October 2013.

The study analyses average retirement age by educational background in Sweden, Denmark, Finland, and Norway, using data from 2008-2010. Focus of the analysis is on retirement that occurs mainly due to advancing age and end-of-career choices, not for reasons of sickness or disability. Accordingly, most calculations are based on the older one-third of the workforce, persons age 50-74.

The goal of the study is not only limited to identify how retirement age varies between educational groups, but also to highlight the differences between the Nordic countries in the subject matter. An additional goal is to construct simple linear projections that show how persons who at present day are at or close to retirement age successively will retire within the coming ten years. A third goal is to strengthen Nordic influence internationally by using methods that can be adapted by other countries, including those countries which lack access to high quality individual-based registers. 
Due to rising educational levels, and the fact that persons with a postsecondary education tend to retire older than persons with a secondary education, actual retirement age will likely rise even in the absence of additional policy changes. The report also shows that Denmark and Finland have lower actual retirement ages than Sweden or Norway, especially among women.

With this report the Nordic Council of Ministers wishes to support efforts to improve pension systems in the Nordic countries, and to contribute to the body of knowledge about future retirements.

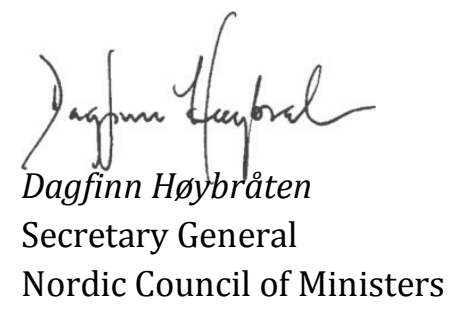




\section{Summary}

The aim of the analysis was show how average retirement age varies by educational level and field of education, and to highlight the differences between countries. A further objective was to make simple linear projections to show how the current stock of working 50-74 year-olds will reduce in size towards the year 2020, primarily to retirement. This report describes the results of the collection and analysis of data in Denmark, Sweden, Norway and Finland.

A model for calculating mean age at retirement using compiled register data was developed by Statistics Sweden in May 2012. The data was compiled from by the statistical agencies in each country from October to December 2012. From February to June 2012, Statistics Sweden combined the data, ran the model, and wrote this report.

Among other things, the results show that changes in the composition of the labout force will happen fairly quickly. Roughly three of four working persons persons age 50 or older in 2008 will retire before the year 2020. A greater portion of persons with a low level of education than a high level of education will retire. Comparing countries, Denmark will see more retirements than other countries and Norway fewer. Denmark and Finland will also see more persons retiring "early" than other countries.

In general, the average retirement age will increase over the next few years, even assuming no significant changes in policy. This is mainly due to the rising educational level and the relatively high retirement age among the highly educated.

The anlaysis also shows how retirement age differs among different fields of education. In general, persons with an education withen healthcare retire relatively young and persons with an education in sciences retire older. These these differences are similar in the four countries. Why they differ is a complex issue that has to do with the incentives individuals face in each country. These incentives depend not only on educational attainment but also on occupation, pension schemes, culture and a range of other factors. 


\section{The studied group}

The studied group consists of persons age 50-74 who had employment income in 2008 and were registered residents of a country in both 2008 and 2009. This 50-74 year-old group makes up about a third of the total employed persons in each county. They have a median age of 56 to 59 years, varying somewhat between countries and by level of education.

\section{Mean retirement age by level of education}

The mean age at retirement in 2009 among persons who were age 50-74 and employed the previous year averaged 63.5 years in the four countries. In Sweden and Norway mean retirement age was higher than average, at 64.4 years and 64.2 years, respectively, and in Denmark and Finland it was lower, at 62.8 years in both countries. Mean retirement age in 2009 was highest among the tertiary-educated (ISCED level 5A/6), at 64.2 years in countries on average, and lowest among persons who have only completed secondary education, at 63.1 years.

\section{Mean retirement age by field of education, secondary level}

According to the model, in the countries studied between 3.8 and 5.8 percent of persons who were 50-74 years old and employed in 2008 retired the following year. The retirement rate for all levels of education combined was highest in Denmark, at 5.8 percent, and lowest in Norway, at 3.8 percent.

For persons whose highest level of education is at the secondary level (ISCED 3) the mean age at retirement in 2009 was 63.1 years. Age at retirement at this educational level was highest in Norway (64.1 years) and Sweden (64.0 years) and lowest in Denmark (62.6 years) and Finland (61.7 years). The most common fields of education at this level include General Programmes; Social science, Business and Law; Engineering, Manufacturing and Construction; and Health and Welfare; Together, these four fields made up three of four employed, secondary-educated persons in countries in 2009. Mean age at retirement among persons with these fields was between 62.0 and 63.3 years, with Health and Welfare having a lower-than-average retirement age, at 62 years.

Among the nine fields of education at the secondary level, Science, Mathematics and Computing had the highest mean retirement age, at 64.6 years in countries on average. 


\section{Mean retirement age by field of education, post-secondary level}

Overall in Nordic countries, retirements in 2009 amounted to 3.9 percent of 50-74 year-olds with a post-secondary education who were employed in 2008. The percentage of retirees was highest in Denmark and Finland, at 4.3 percent, and lowest in Norway, at 2.7 percent.

The mean age at retirement in 2009 for persons who had completed a post-secondary education and were employed the previous year was 64.0 years. Retirement age was highest in Sweden (64.8 years) and Norway (64.7 years) and lowest in Denmark (63.5 years) and Finland (63.2 years).

Within the fields of education and between countries, mean retirement age varied from roughly 61 years to as high as 67 years, but was commonly around 63 to 64 years. The most common fields of education at the post-secondary level are Teacher training and education; Health; and Business and administration. Together, these three fields comprised roughly half of employed, although the proportions vary between countries. Average age at retirement within these three fields ranged from 63.7 years to 64.1 years. The field Agriculture and veterinary had the highest mean retirement age, at 66.1 years, although this group is small in all countries.

\section{Projections}

In the countries studied, between 60 and 75 percent of persons who were age 50-74 and employed in 2008 will have retired by 2020 . The proportion of projected retirements is higher at low levels of education, and lower at high levels of education. The projections are similar in all countries. 



\section{Sammanfattning}

Syftet med analysen var att visa hur den genomsnittliga pensionsåldern varierar beroende på utbildningsnivå och utbildningsinriktning, samt att belysa skillnader mellan länderna. Ett annat syfte var att göra enkla linjära framskrivningar för att visa hur den nuvarande stocken av sysselsatta i åldern 50-74 år kommer att minska i storlek fram till 2020 att minska i storlek mot år 2020 på grund av pensioneringar. Rapporten redovisar resultatet av datainsamling och analys för Danmark, Sverige, Norge och Finland.

En modell för att skatta medelåldern vid pensionering baserad på registerstatistik utvecklades av Statistiska centralbyrån (SCB) i Sverige under perioden april-maj 2012. Data samlades in från deltagande statistikbyråer mellan oktober och december 2012. Mellan februari och juni 2013 sammanställde SCB insamlade data, körde modellen och skrev rapporten.

Resultaten visar bland annat att förändringar i arbetskraften kommer att ske ganska snabbt. Cirka tre av fyra sysselsatta personer i åldern 50år och uppåt år 2008 kommer att går i pension innan år 2020. En större andel personer med låg utbildningsnivå än med hög utbildningsnivå kommer att gå i pension. Om nuvarande trender fortsätter kommer Danmark ha relativt fler pensionsavgångar än andra länder och Norge kommer ha färre. Danmark och Finland kommer också ha fler personer som pensioneras "tidigt" än andra länder.

Generellt sett kommer den genomsnittliga pensionsåldern öka under de närmaste åren, även om man antar att det inte sker några större förändringar i pensionsregler. Detta följer av en ökande utbildningsnivå och att personer med hög utbildningsnivå har en relativ hög pensionsålder.

Denna analys visar också hur pensionsåldern varierar mellan olika utbildningsinriktningar. Dessa skillnader är likartade i de fyra länderna. Att det finns skillnader beror på vilka incitament som individerna ställs inför i de enskilda länderna. Förklaringen är komplex och berör på mer än bara utbildning, utan också yrke, pensionsregler, kultur och en mängd andra faktorer. 


\section{Den studerade gruppen}

Den studerade gruppen består av personer i åldern 50-74 år som hade inkomst från anställning år 2008 och som var folkbokförda i ett land under år 2008 och 2009. Den här gruppen omfattar ungefär en tredjedel av den totala befolkningen med inkomst från anställning i alla fyra länder. Gruppen har en medianålder på mellan 56 och 59 år, som varierar något mellan länder och mellan de olika utbildningsnivåerna.

\section{Genomsnittlig pensionsålder efter utbildningsnivå}

Medelåldern vi pensionering år 2009 bland personer som var i åldern 50-74 år och sysselsatta år 2008 var 63,5 år i de nordiska länderna som grupp. I Sverige och Norge var pensionsåldern högre än genomsnittet, 64,4 år respektive 64,2 år. I Danmark och Finland var pensionsåldern lägre än genomsnittet - 62,8 år i både länderna. Den genomsnittliga pensionsåldern år 2009 var högst bland personer med eftergymnasial utbildning, 64,2 år, och lägst bland personer som endast har avslutad gymnasieutbildning, 63,1 år.

\section{Gymnasial nivå}

Enligt modellen gick, i de studerade länderna, mellan 3,8 procent och 5,8 procent av alla personer som var 50-74 år gamla och som var anställda år 2008 i pension året därpå. Andelen som gick i pension var högst i Danmark, 5,8 procent, och lägst i Norge, 3,8 procent. Bland personer vars högsta utbildning är på gymnasienivå (ISCED 3) var medelåldern vid pensionering 63,1 år. Åldern vid pensionering för personer med denna utbildningsnivå var högst i Norge och Sverige, 64 år, och lägst i Danmark och Finland, 62,6 respektive 61,7 år.

De vanligaste utbildningsinriktningarna bland personer med högst gymnasieutbildning är samhällskunskap, handel och juridik, teknik och tillverkning, samt hälso- och sjukvård. I de grupperna låg pensionsåldern år 2009 mellan 62 och 63,3 år. Personer med en utbildning inom hälso- och sjukvård har en betydligt lägre pensionsålder än andra inriktningar, 62 år. Personer med gymnasieutbildning inom vetenskap, matematik eller data har en högre pensionsålder än personer med andra inriktningar, 64,6 år.

\section{Eftergymnasial nivå}

Totalt sett i Norden uppgick pensionsavgångarna under år 2009 till 3,9 procent av alla 50-74-åringar med eftergymnasial utbildning och som hade en inkomst från anställning år 2008. Den procentuella andelen pensioneringar var högst i Danmark och Finland, 4,3 procent, och lägst i Norge, 2,7 procent. 
Medelåldern vid pensionering år 2009 för personer med avslutad eftergymnasial utbildning och som var anställda år 2008 uppgick till 64,0 år, nästan ett år äldre än för personer med höst gymnasial utbildning. Pensionsåldern bland eftergymnasialt utbildade var högst i Sverige $(64,8$ år) och Norge (64,7 år) och lägst i Danmark (63,5 år) och Finland (63,2 år).

Pensionsåldern varierade från cirka 61 år till så mycket som 67 år inom de olika utbildningsinriktningarna i de olika länderna. Nivån låg dock oftast mellan 63 och 64 år. De vanligaste utbildningsområdena på eftergymnasial nivå är lärarutbildning, hälso- och sjukvård samt ekonomi och administration. Tillsammans omfattar dessa tre områden ungefär hälften av de sysselsatta, även om proportionerna varierar något mellan länderna. Medelåldern vid pensionering inom dessa tre områden varierade från 63,7 år till 64,1 år. Inriktningen jordbruk och djursjukvård hade den högsta genomsnittliga pensionsåldern, 66,1 år, men denna grupp är relativ liten i alla länder.

\section{Framskrivningar}

I de studerade länderna kommer mellan 60 och 75 procent av de som var i åldern 50-74 år och som var anställda 2008 att ha gått i pension år 2020. Andelen förväntade pensionsavgångar är högre vid låga utbildningsnivåer, och lägre vid höga utbildningsnivåer. Bedömningarna är likartade i alla länder.

\subsection{Employed persons in Nordic countries}

All population projections over last few decades have shown that the European population is getting older. Fertility rates have decreased below replacement values in many countries, and increasing life expectancies allow more people to live longer lives. At the same time, populations in northern European countries are expected to grow over the next fifty years, the proportion of persons of working age is expected to decrease, and the number of retirees is expected to increase.

The number of people who will retire in coming years depends on the age distribution of working people today. The distribution of the employed population by age is similar to that of the population overall, except that there are fewer persons age 20 and younger and age 50 and older. These younger and older persons are less likely than others to work, of course, and the bulk of the non-working population is age 65 and older.

In this report, the studied population consists of persons who were registered residents in both 2008 and 2009 and were age 16 or older in 2008 , with a focus on the 50-74 year-old portion of that group who had 
employment income in 2008. Using two years' data for the same individuals enables us to track changes in employment status between years. The studied population is smaller than a county's population in any given year because it excludes persons age 15 and younger as well as persons who were not residents in both years. Overall, the studied group is between 79 percent and 83 percent as large as each country's population in 2008.

In the model, persons with employment income are classified as "employed" whereas those who lack employment income are classified as "retired." Since the analysis focuses on 50-74 year-olds, no separate definition younger persons who lack employment income has been made.

Figures 1-4 show the size of the groups of "employed" and "retired" in each country by age. The innermost shaded areas represent persons who had employment income in 2008; the outer shaded areas represent persons who lacked employment income in 2008.

As can be seen in these figures, persons who are already retired comprise a large portion of the population. Although many retirees are 75 or older, non-working 50-74 year-olds are a large group by themselves. In Norway in 2008, such "retired" persons comprised 36 percent of all 5074 year-olds who were resident in 2008 and 2009. In Finland, 51 percent of this age group were already retired in 2008; in Denmark, 46 percent; and in Sweden, 41 percent. 
Figure 1. Men and women with/without employment income among residents of Denmark in 2008 and 2009

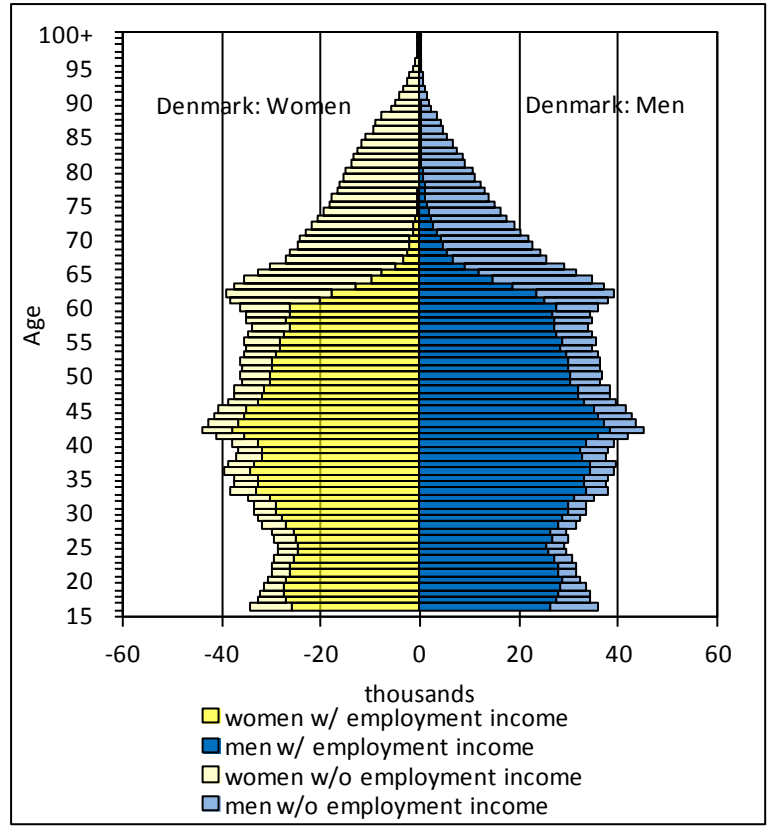

Source: Statistics Denmark.

Figure 2. Men and women with/without employment income in 2008 among residents of Sweden in 2008 and 2009

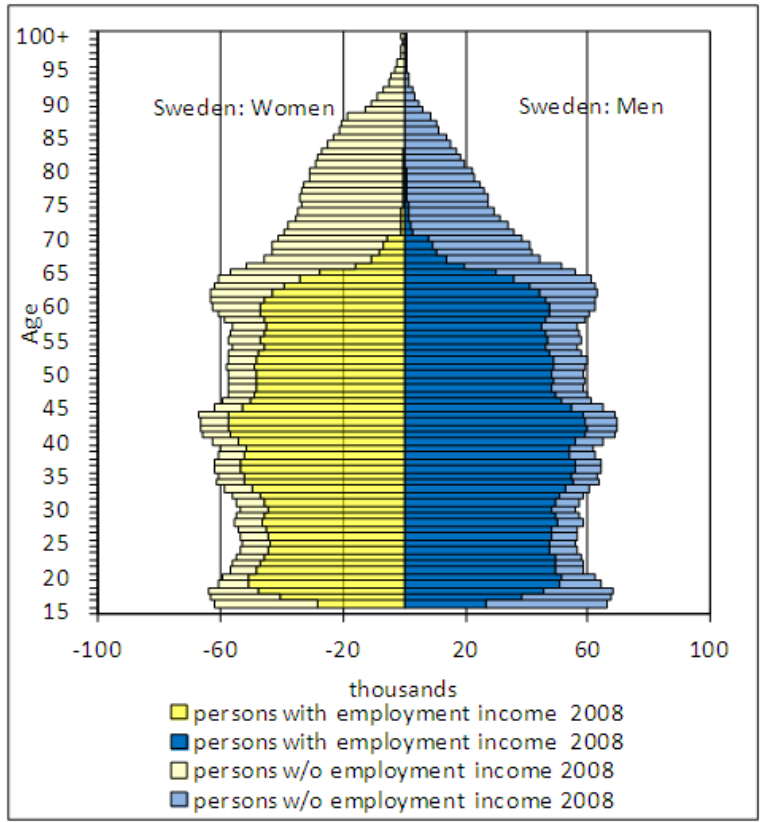

Source: Statistics Sweden. 
Figure 3. Men and women with/without employment income among residents of Norway in 2008 and 2009

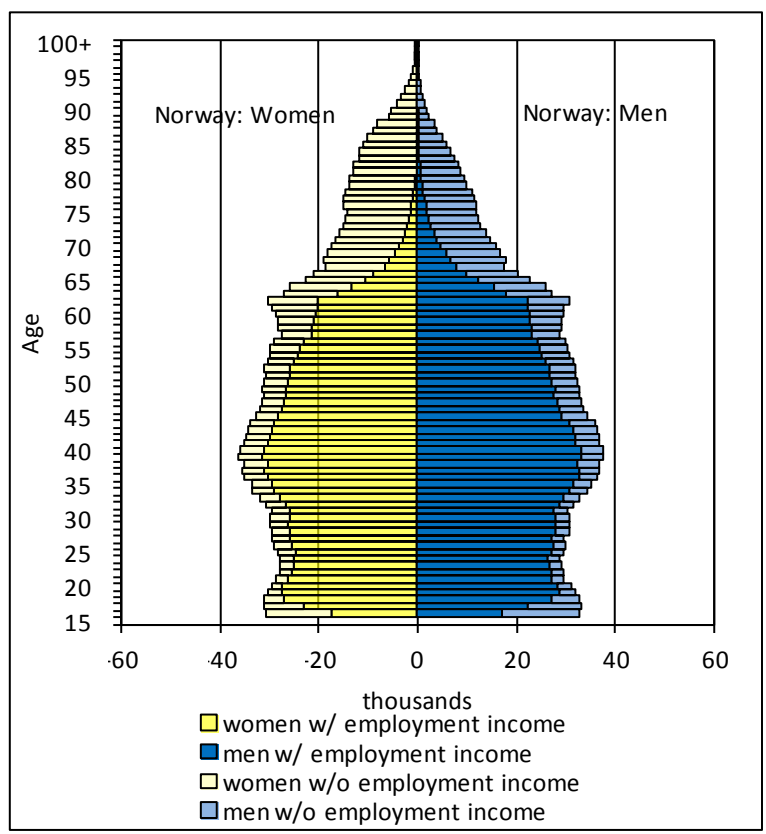

Source: Statistics Norway.

Figure 4. Men and women with/without employment income among residents of Finland in 2008 and 2009

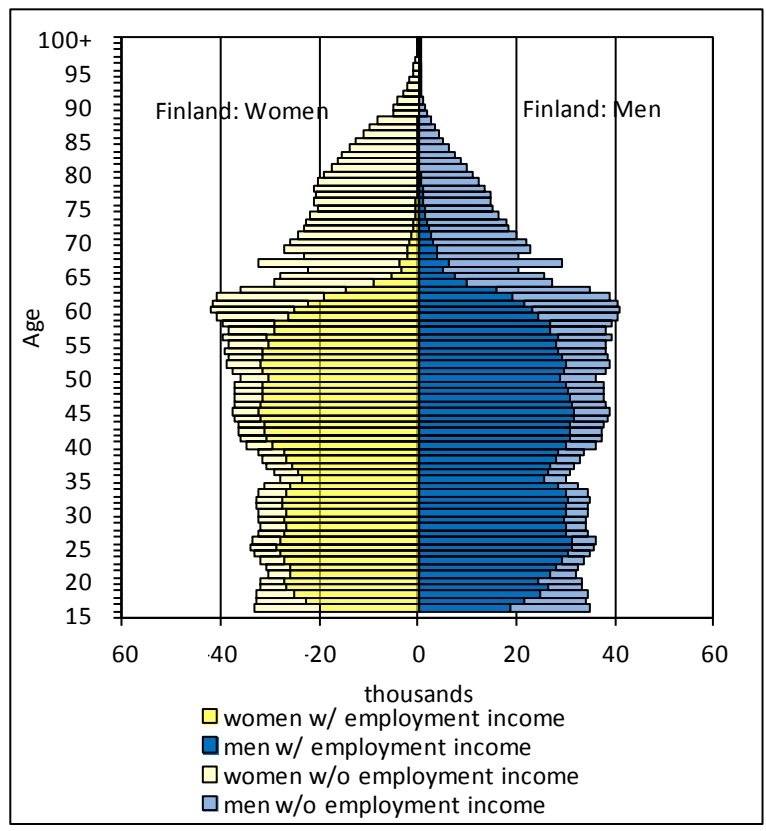

Source: Statistics Finland. 
Persons who were residents in both 2008 and 2009 had a median age of 46 years in Denmark and Sweden, 47 years in Finland and 45 years in Norway. Within that group, the portion that had income from employment in 2008 was five to six years younger, with a median age of 41 years in Denmark, Sweden and Finland and 45 years in Norway. On average, employed persons are younger than residents overall because of the large number of retired older residents who lack employment income.

Table 1. Number and age of persons who were registered residents in both 2008 and $2009(000)$

\begin{tabular}{lrrrr}
\hline & Denmark & Sweden & Norway & Finland \\
\hline registered residents in 2008 and 2009 (000) & 4,342 & 7,472 & 3,763 & 4,311 \\
median age & 46 & 46 & 45 & 47 \\
of whom had employment income 2008 (000) & 2,944 & 4,951 & 2,750 & 2,750 \\
(percent of registered residents) & 68 & 66 & 72 & 64 \\
median age & 41 & 41 & 40 & 41 \\
of whom were age 50-74 (000) & 8,48 & 1,545 & 790 & 823 \\
(percent of persons with empl. income) & 29 & 31 & 29 & 30 \\
median age & 57 & 58 & 57 & 56 \\
\hline
\end{tabular}

Source: Statistics Denmark, Sweden, Norway and Finland.

Nordic countries have similar distributions of educational background among their employed populations. In all countries, persons whose highest level of education is at the secondary level comprise the largest portion of employed persons overall. In Sweden, this group made up 47 percent of persons who had employment income in 2008 and were residents in 2008 and 2009. Secondary-educated persons comprised 44 percent of employed in Finland, 43 percent in Denmark and 40 percent in Norway. Among the employed in all countries, having a highest level of education at the secondary level is more common among men than among women.

Persons who have completed a tertiary-level educated comprise a large and growing group. In Denmark and Sweden in 2008, tertiaryeducated persons made up 29 percent of all persons with employment income. In Finland and Norway the proportions of tertiary-educated were higher, at 32 percent and 35 percent of employed, respectively.

Women made up 56 percent of all employed in 2008 in Nordic countries overall. In all countries, women are more likely than men to have completed a tertiary level education. In each country, the proportion of employed women with a tertiary-level education exceeds the proportion of men with a tertiary-level education by 7-10 percentage points. 
Table 2. Persons with employment income in $\mathbf{2 0 0 8}$ who were registered residents in 2008 and 2009 by ISCED 1997 level of education. Percent

\begin{tabular}{|c|c|c|c|c|}
\hline & Denmark & Sweden & Norway & Finland \\
\hline \multicolumn{5}{|l|}{ Men } \\
\hline Primary (ISCED 1+2) & 27 & 19 & 24 & 23 \\
\hline Secondary (ISCED $3^{1}$ ) & 45 & 49 & 41 & 47 \\
\hline Post-secondary non-tertiary (ISCED 4) &.. & 7 & 4 & 1 \\
\hline Short-cycle tertiary (ISCED 5B) & 6 & 6 & 3 & 10 \\
\hline Bachelor/master/doctoral (ISCED 5A/6) & 19 & 18 & 25 & 20 \\
\hline Total ${ }^{2}$ & 100 & 100 & 100 & 100 \\
\hline Total (000) & 1,511 & 2,520 & 1,401 & 1,387 \\
\hline \multicolumn{5}{|l|}{ Women } \\
\hline Primary (ISCED 1+2) & 24 & 14 & 22 & 18 \\
\hline Secondary (ISCED $3^{1}$ ) & 41 & 45 & 38 & 42 \\
\hline Post-secondary non-tertiary (ISCED 4) & .. & 6 & 2 & 1 \\
\hline Short-cycle tertiary (ISCED 5B) & 5 & 10 & 1 & 16 \\
\hline Bachelor/maser/doctoral (ISCED 5A/6) & 28 & 24 & 34 & 23 \\
\hline Total $^{2}$ & 100 & 100 & 100 & 100 \\
\hline Total (000) & 1,433 & 2,431 & 1,315 & 1,363 \\
\hline \multicolumn{5}{|l|}{ Men \& women } \\
\hline Primary (ISCED 1+2) & 26 & 17 & 23 & 21 \\
\hline Secondary (ISCED $3^{1}$ ) & 43 & 47 & 40 & 44 \\
\hline Post-secondary non-tertiary (ISCED 4) & .. & 7 & 3 & 1 \\
\hline Short-cycle tertiary (ISCED 5B) & 5 & 8 & 2 & 13 \\
\hline Bachelor/maser/doctoral (ISCED 5A/6) & 23 & 21 & 30 & 22 \\
\hline Total $^{2}$ & 100 & 100 & 100 & 100 \\
\hline Total (000) & 2,944 & 4,951 & 2,717 & 2,750 \\
\hline
\end{tabular}

${ }^{1}$ Includes levels 3 and 4 for Denmark.

${ }^{2}$ Includes includes unknown level.

Source: Statistics Denmark, Sweden, Norway and Finland.

Overall, the populations of Nordic countries are similar with regards to the proportion of the population who have employment, the proportion of employed persons approaching retirement (age 50-74 years), educational attainment, and gender patterns in educational attainment.

The median age of employed 50-74 year olds is between 56 and 59 depending on educational level, with small differences between countries. In general, employed 50-74 year olds with ISCED 1-2 level of education have a higher median age than those with an ISCED 5A/6 education, because lower levels of education are more common in older age groups.

Table 3. Median age of employed 50-74 year-olds who were registered residents in both 2008 and 2009 by ISCED level of education

\begin{tabular}{lcccc}
\hline & Sweden & Denmark & Finland & Norway \\
\hline ISCED levels 1+2 & 59 & 57 & 58 & 58 \\
ISCED levels 3+4 & 57 & 57 & 56 & 58 \\
ISCED levels 5A/6 & 58 & 57 & 56 & 57 \\
\hline
\end{tabular}

Source: Statistics Denmark, Sweden, Norway and Finland. 
Although the median age of employed 50-74 year-olds is similar in all four countries, the distribution of age varies between countries and by educational level. In Denmark, for example, 36 percent of 50-74 yearolds with highest primary education (ISCED levels 1 or 2) are younger than 55, compared to 24 percent in Sweden.

On the other hand, persons age 60 and older comprise 49 percent of employed 50-74 year olds at this educational level in Sweden, and 35 percent in Denmark. Thus, the size of Sweden's employed 50+ population is weighted towards older age groups, whereas Denmark's is weighted towards younger age groups. In Finland and Norway, the age distribution of ISCED level 1-2 educated 50+ year-olds is more evenly among the 5-year age groups than it is in Denmark and Sweden.

The difference in age distributions may suggest that more of Sweden's employed 50-74 year-olds will retire than other countries', or that they may retire sooner. However, the decision to retire is affected by many factors, not just age, and these factors are specific to each country.

Figure 5. Age distribution of employed 50-74 year-olds who were registered residents in both 2008 and 2009, ISCED levels of education 1-2

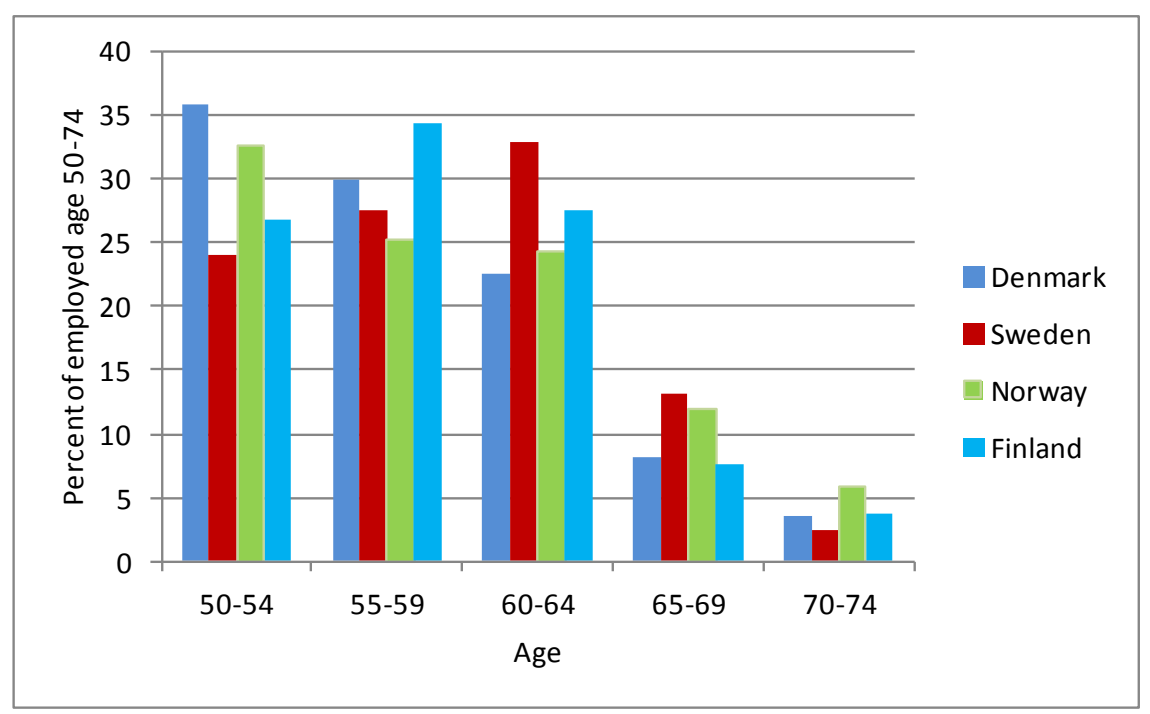

Source: Statistics Denmark, Sweden, Norway and Finland.

At the ISCED 3-4 level, Finland's employed 50-74 year-olds have a median age of 56, compared to 57 in Sweden and Denmark and 58 in Norway. Roughly third of employed ISCED level 3-4-educated 50-74 yearolds are younger than age 55 in Denmark, Norway and Sweden, compared to 41 percent in Finland. Just 23 percent of this group in Finland is 
older than 60, compared to 32 percent in Denmark, 36 percent in Sweden and 38 percent in Norway.

Figure 6. Age distribution of employed 50-74 year-olds who were registered residents in both 2008 and 2009, ISCED levels of education 3-4

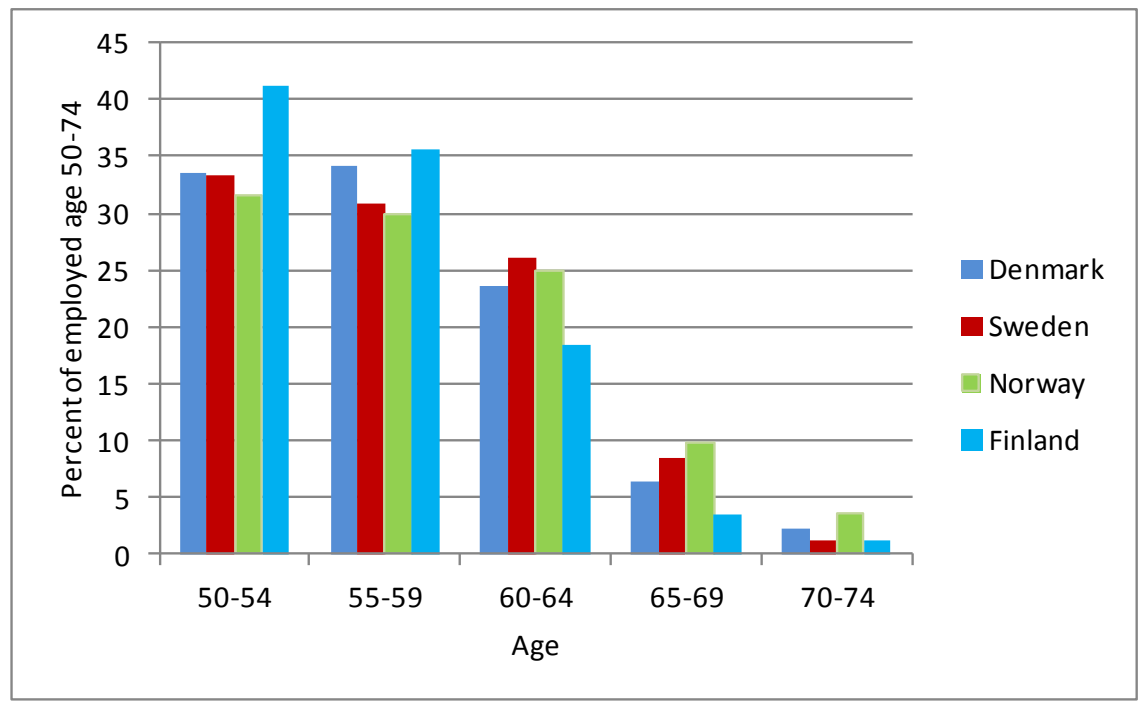

Source: Statistics Denmark, Sweden, Norway and Finland.

Among ISCED 5-6-educated, Finland also shows a larger proportion of 50-59 year-olds than other countries, and a lower proportion of persons age 60 and older. This difference is not as pronounced as it is at level $5 \mathrm{~A}-6$ as it is at level 3-4, but may indicate that Finland could see fewer retirements among 50-74 year-olds with this educational level than other countries will. But it should be kept in mind that a person's age is just one of the many country-specific factors that influence the age at which they retire, and that these factors change over time. 
Figure 7. Age distribution of employed 50-74 year-olds who were registered residents in both 2008 and 2009, ISCED levels of education 5-6

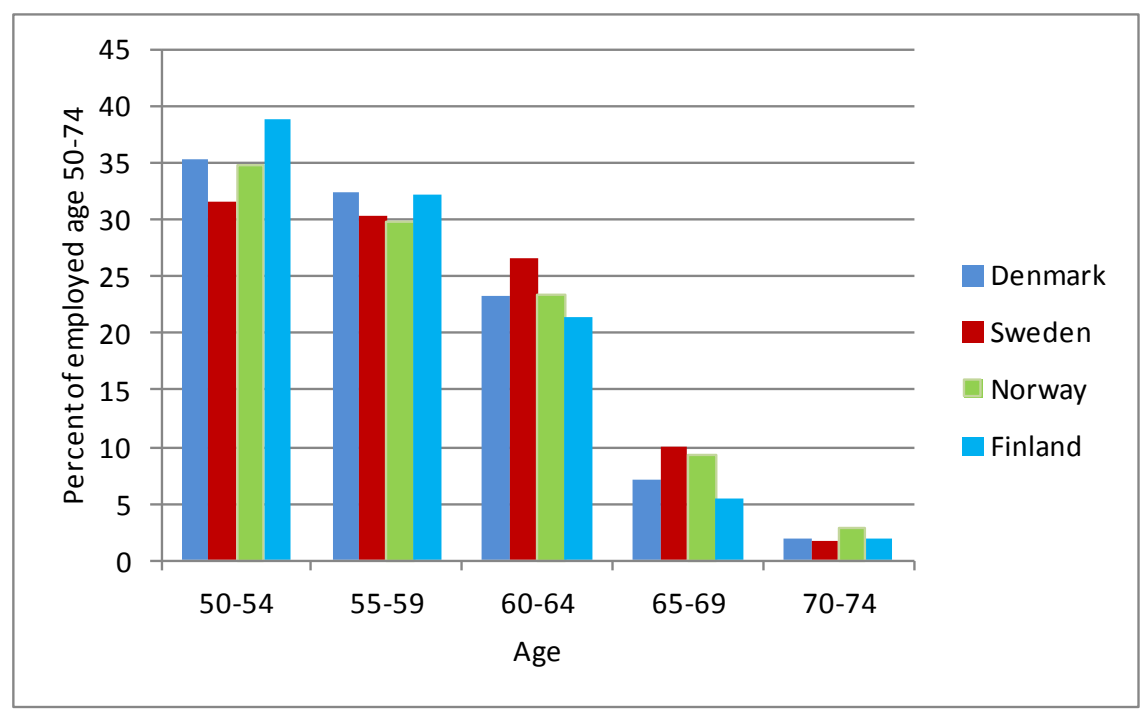

Source: Statistics Denmark, Sweden, Norway and Finland.

\subsection{Legislated pension systems and retirement ages}

Nordic countries have flexible retirement ages. In general, individuals choose when they want to retire, and the amount of their national pension is larger if they choose to retire later. In addition to national pension schemes, each country has various occupational pension systems and private pension insurances and savings schemes. An individual who has worked will generally receive pension payments from several sources. In general, the total amount of these payments depends on when a person chooses to retire, their income at retirement, their total income over their lifetime, growth in pension savings and/or credits over time as they were accumulated, and each countries' specific pension regulations.

There is no single statutory retirement age in Nordic countries. The age at which one becomes elibible for a pension varies between countries. It is also different for different occupational pensions and for private insurance and savings shemes.

\section{Denmark}

The Danish pension scheme consists of three parts - a national public pension, occupational pension schemes, and private pension savings. The statutory retirement age is 60-67. Early retirement has been possible through a pension scheme from the unemployment insurance. Exit- 
ing the labour market through this system has been common in Denmark. Since the pension reform of 2011, early retirement is expected to become less common after 2018. However, the reform does not affect people born before 1959, so it is unclear what affect these changes will have on the phenomenon of early retirement over the next ten years.

\section{Sweden}

The Swedish pension system consists of a national pension based on earnings, earnings occupation pensions, and private pensions. There is a flexible retirement age to qualify for the national pension from 61-67. Generally, delaying the withdrawal of pension increases the size of the pension.

Sweden's pension system was reformed in 1999, and the new system is gradually replacing the old. Persons who will retire up to the year 2020 will be partially covered on the the old system and partially the new. Under the new system the national pension is based on lifetime earnings and one can continue to work while drawing a pension. Since the pension amount is based on lifetime earnings, the earlier one draws a pension the lower the amount of the pension.

\section{Finland}

The Finnish pension system consists a basic state pension and statutory earnings-related schemes. The statutory retirement age is $63-68$. The schemes for private-sector employees are partially pre-funded while the public-sector schemes are pay-as-you-go financed.

The Finish pension system was reformed in 2005. The main effect of this reform is that pensions are calculated on lifetime earnings rather than ending salary. The flexible retirement age from 63-68 was introduced, and the calculation of the amount of pension now consideres the impact of rising life expectancy. Certain pensions for the unemployed were abolished. The effects of these reforms have not yet been fully felt but it is expected that pension amoutns will be lower. Through an agreement with Finnish trade unions and employer organisations Finland also hopes to raise the average retirement age by three years by 2025 .

\section{Norway}

The Norwegian pension system is made up of three parts. It consists of a national insurance, various occupational pension schemes, and different forms of savings specifically for retirement. The Norwegian pension system was reformed starting in 2009. The statutory retirement age is now flexible from age 62-75. From the year 2011 it is possible to combine work and pension fully or partly from age 62 . 


\subsection{Average age at retirement - definition}

\section{Average age at retirement}

The model used to calculate average age at retirement and to make projections is based on the number of persons who were registered residents in on 31st December 2008 and 31st December 2009, divided into one-year age groups.

A person is defined as "employed 2008" if they had income from employment in 2008 and were registered residents on 31st December 2008 and 31st December 2009. From the "employed 2008" group, a person is further defined as either "employed 2009" or "retired in 2009." The "employed 2009" group consists of the persons who were "employed 2008" and had employment income in 2009. The "retired in 2009" group consists of persons who were "employed in 2008" and either 1) lacked employment income and had pension income in 2009 and 2010; or, 2) lacked employment income and had pension income in 2009 but were not a registered resident in 2010. The latter rule allows for emigration and death.

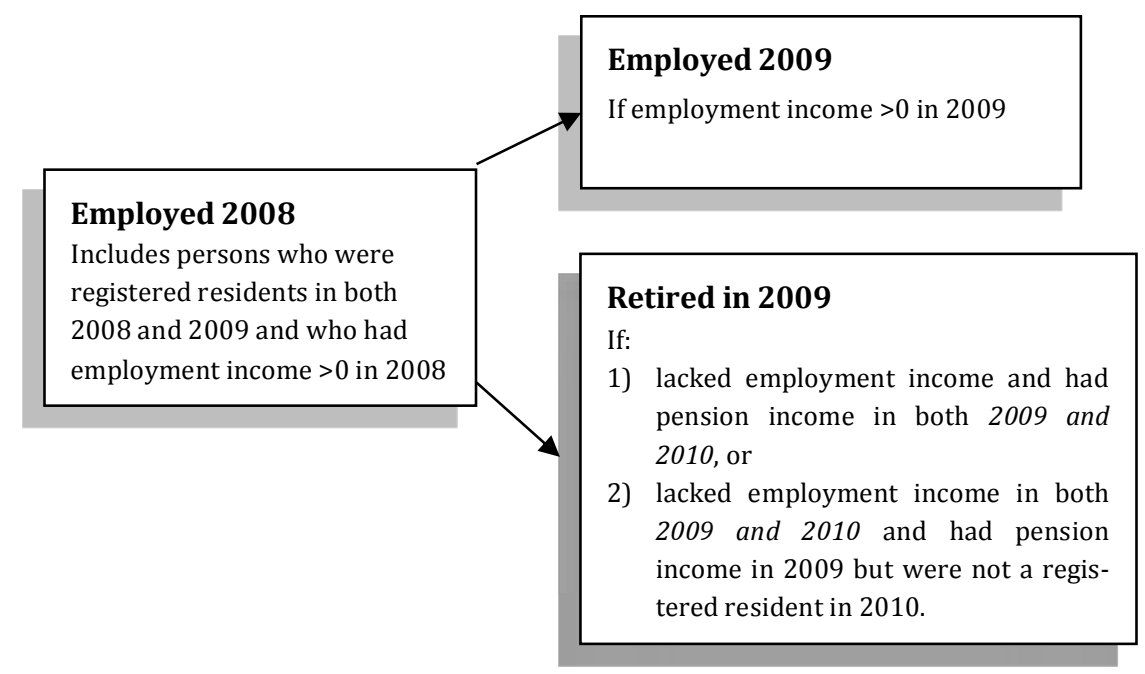

Average age at retirement is calculated as the mean age in 2009 of all persons who were classified in the group "retired in 2009" and were age 50-74 in 2008. Persons who were younger than 50 years in 2008 are not included; they are removed in order to remove most of the affects of early retirement due to sickness, disability and other factors that not related to age or end-of-career decisions.

Persons who died in 2009 are not part of the analysed population, nor are persons who retired before 2009. Neither the amounts of em- 
ployment and pension incomes nor capital income are considered. The model includes business owners if they had income from employment.

\section{Projections}

The projections show how quickly various groups of persons who were employed and age 50-74 in 2008 will become retirees over the period 2010-2020, based on the observed rates of retirement among different age groups in 2009. The purpose of the projections is to highlight differences between levels of education, fields of education and countries.

The projections show the growth in the number of retirees as a cumulative percent of the size of the original group of "employed in 2008". For the purposes of the projections, a person is defined as "employed 2009 " or "retired in 2009" using the same criteria used for calculating mean retirement age.

The "retired in 2009" group constitutes a proportion of the "employed 2008" group, with a unique proportion for each 1-year age group. These proportions are used to project the number of retirements in each 1-year age group, based on the number of employed persons the previous year. In each projection year, total retirements is the sum of projected retirements in the 1-year age groups. In successive projection years, the number of persons available to retire (i.e. "employed") is reduced by the number of retirements the previous year, for each 1-year age group.

For example, the number of 52 year-olds who "retired in 2010" is projected as the number of 51 year-olds who were "employed 2009", multiplied by the proportion 52 year-olds who retired in 2009. In the following year, the number of 53 year-olds available to retire is equal to the number of "employed in 2008" 51 year-olds, less 52 year-olds who "retired in 2010".

Note that the projections are based only persons who were age 5074 in 2008, and do not include younger persons will become part of that age group during the projection period.

This model, like any model, is a simplification that does not capture all aspects the transition from employment to retirement. The model draws a sharp distinction between the state of being "employed" and "retired", whereas is reality persons can be both. This sharp distinction was drawn in order to make comparisons between countries and levels and fields of education given the current availability of data.

For more information, see section 1.7 Strengths and limitations of the analysis 


\subsection{Average age at retirement by level of education}

In Nordic countries, the educational level of employed 50-74 year-olds differs little from that of employed persons overall. The most common highest completed level of education is the secondary level, ISCED 3, at 43 percent of persons age 50-74 and employed in 2008 who were registered residents in 2008 and 2009. One in three persons in this 50-74 year-old group has completed tertiary education (ISCED levels 5-6), and one in five has completed just primary education (ISCED levels 1-2). Small percentages in each country have a post-secondary, non-tertiary (ISCED level 4) education as their highest level of education.

Table 4. Highest level of education among persons who were age 50-74 and employed in 2008 and registered residents in 2008 and 2009. Percent

\begin{tabular}{lrrrrrr}
\hline & & \multicolumn{5}{c}{ ISCED 1997 level of education } \\
\cline { 3 - 7 } & $\mathbf{1 + 2}$ & $\mathbf{3}^{\mathbf{1}}$ & $\mathbf{4}$ & $\mathbf{5 b}$ & $\mathbf{5 A / 6}$ & total $^{\mathbf{2}}$ \\
\hline Sweden & 20 & 45 & 5 & 10 & 20 & 100 \\
Denmark & 24 & 43 &.. & 6 & 26 & 100 \\
Finland & 25 & 38 & 0,5 & 18 & 18 & 100 \\
Norway & 18 & 47 & 3 & 3 & 28 & 100 \\
country average & 22 & 43 & 3 & 9 & 23 & 100 \\
\hline
\end{tabular}

${ }^{1}$ Includes levels 3 and 4 for Denmark.

${ }^{2}$ Includes "unknown" level.

Source: Statistics Denmark, Sweden, Norway and Finland.

According to the model, in the countries studied between 3.8 and 5.8 percent of persons who were 50-74 years old and employed in 2008 retired the following year. The retirement rate for all levels of education combined was highest in Denmark, at 5.8 percent, and lowest in Norway, at 3.8 percent.

Retirement in 2009 was especially common among persons with a low level of education, averaging in countries 7.4 percent of the previous year's employed 50-74 year-olds whose highest level of education was at the primary level, ISCED level 1-2. Finland's retirement rate in this educational group was higher than other countries', at 8.7 percent of the previous year's employed, and Norway's was lower, at 5.6 percent.

Secondary-educated persons comprise a large group in all countries, averaging 43 percent of employed 50-74 year-olds in 2008 and 47 percent in Sweden. In average in countries, five percent of employed persons with this educational level retired in 2009. Norway had lower-than-average retirements in this group, at 3.9 percent, and Denmark higher, at 5.9 percent.

Level 4 (post-secondary, non-tertiary) stands out as having a low proportion of persons who retired in 2009, on average in countries 2.4 
percent of the previous year's employed 50-74 year-olds. For Denmark, persons with a level 4 education are grouped together with and comprise a part of level 3.

Table 5. Retirements in $\mathbf{2 0 0 9}$ by level of education. Percent of persons who were age 50-74 and employed in 2008 and registered residents in 2008 and 2009

\begin{tabular}{lrrrrrr}
\hline & & \multicolumn{5}{c}{ ISCED 1997 level of education } \\
\cline { 3 - 8 } & $\mathbf{1 + 2}$ & $\mathbf{3}^{\mathbf{1}}$ & $\mathbf{4}$ & $\mathbf{5 b}$ & $\mathbf{5 A / 6}$ & total $^{\mathbf{2}}$ \\
\hline Sweden & 7.7 & 5.2 & 3.1 & 4.6 & 4.1 & 5.3 \\
Denmark & 7.5 & 5.9 &.. & 4.6 & 4.3 & 5.8 \\
Finland & 8.7 & 5.0 &.. & 4.5 & 4.2 & 5.7 \\
Norway & 5.6 & 3.9 & 2.8 & 2.6 & 2.7 & 3.8 \\
country average & 7.4 & 5.0 &.. & 4.1 & 3.8 & 5.1 \\
did not retire & 92.6 & 95.0 &.. & 95.9 & 96.2 & 94.9 \\
\hline
\end{tabular}

${ }^{1}$ Includes levels 3 and 4 for Denmark.

${ }^{2}$ Includes includes "unknown" level.

Source: Statistics Denmark, Sweden, Norway and Finland.

The mean age at retirement in 2009 among persons who were age 5074 and employed the previous year averaged 63.5 years in the four countries. In Sweden and Norway mean retirement age was higher than average, at 64.4 years and 64.2 years, respectively, in Denmark and Finland it was lower, at 62.8 years in both countries.

Table 6. Mean age at retirement in $\mathbf{2 0 0 9}$ by level of education

\begin{tabular}{lrrrrrr}
\hline & & \multicolumn{5}{c}{ ISCED 1997 level of education } \\
\cline { 3 - 7 } & $\mathbf{1 + 2}$ & $\mathbf{3}^{\mathbf{1}}$ & $\mathbf{4}$ & $\mathbf{5 b}$ & $\mathbf{5 A / 6}$ & total $^{\mathbf{2}}$ \\
\hline Sweden & 64.7 & 64.0 & 64.0 & 64.5 & 65.1 & 64.4 \\
Denmark & 62.6 & 62.6 &.. & 63.1 & 63.5 & 62.8 \\
Finland & 63.5 & 61.7 &.. & 62.7 & 63.7 & 62.8 \\
Norway & 63.9 & 64.1 & 64.1 & 65.1 & 64.7 & 64.2 \\
country average & 63.7 & 63.1 &.. & 63.9 & 64.2 & 63.5 \\
\hline
\end{tabular}

${ }^{1}$ Includes levels 3 and 4 for Denmark.

${ }^{2}$ Includes "unknown" level.

Source: Statistics Denmark, Sweden, Norway and Finland

Mean retirement age in 2009 was highest among the tertiary-educated (ISCED level 5A/6), at 64.2 years in countries on average, and lowest among persons who have only completed secondary education, at 63.1 years.

The higher retirement age among tertiary-educated compared to secondary-educated is consistent in all countries. The difference is greatest in Finland, where tertiary-educated persons retired two years older than secondary-educated persons in 2009. In other countries, the difference was 1.1 years or less. 
At ISCED level 3, Finland stands out as having the lowest mean retirement age in 2009, at 61.7 years. This is a year younger than secondaryeducated in Denmark, and a little more than two years younger than secondary-educated in Sweden and Norway. Part of the reason may be that secondary-educated with employment income are, on average, younger in Finland than in other countries, with a median age of 38 compared to 41 in Sweden and Denmark and 42 in Norway. The group of 50-74 year-olds in Finland also have an age distribution weighted towards 50.

In Denmark and Finland, the lower-than average retirement ages are also related to an early pension schemes that have been reformed in recent years. The extent to which these reforms will affect retirements over the next ten years is uncertain.

Figure 8. Mean age at retirement in 2009, men and women, all levels of education

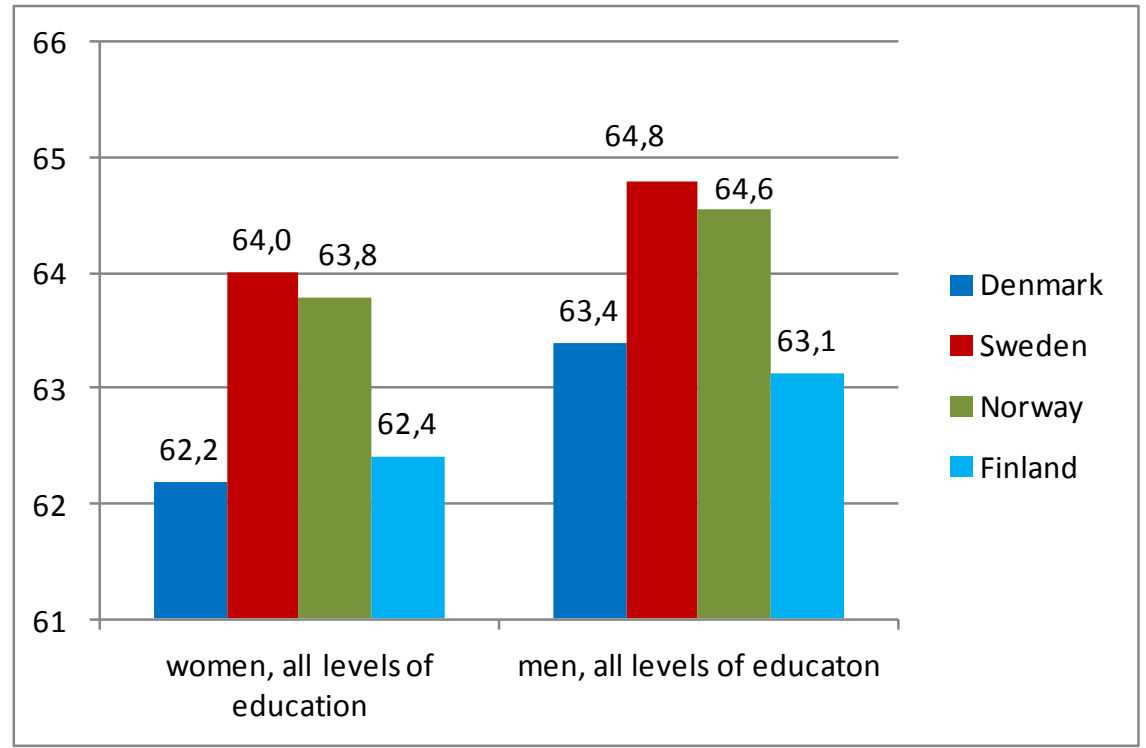

Source: Statistics Denmark, Sweden, Norway and Finland.

In all countries, the average retirement age for women was lower than for men. This pattern was consistent for all levels of education. The one exception is Finland, where ISCED level 3 (upper secondary) educated men and women retired at age 61.7.

The difference between men and women was greatest in Denmark, where men retired at an average age of 63.4 years and women at 62.2 years. Within Denmark, the difference between men and women was greatest at the tertiary level. Men with an ISCED level 5A/6 education in Denmark retired at 64.5 years, whereas women at this level retired at 62.6 years. 
In Finland and Norway, the difference between men and women's retirement age at the tertiary level was smaller than in Denmark, at a little more than a year. Among retirees with just primary education as well as those with secondary education the difference between men and women was smaller, at less than one year.

In Sweden, men with a tertiary education retired at 65.3 years and women at 64.8 years. For retirees in Sweden with a secondary education the difference in retirement age between men and women was less than a year, and was also less than a year for retirees with just a primary education.

Figure 9. Mean age at retirement in 2009, ISCED level 1-2

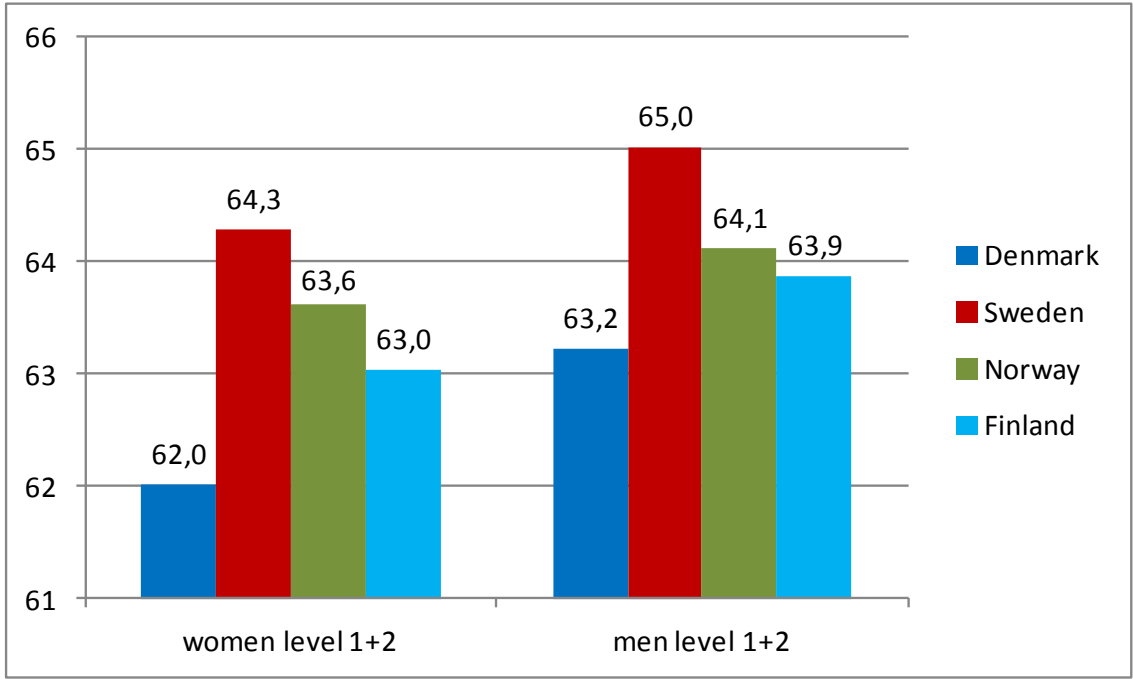

Source Statistics Denmark, Sweden, Norway and Finland. 
Figure 10. Mean age at retirement in 2009, ISCED level 3-41

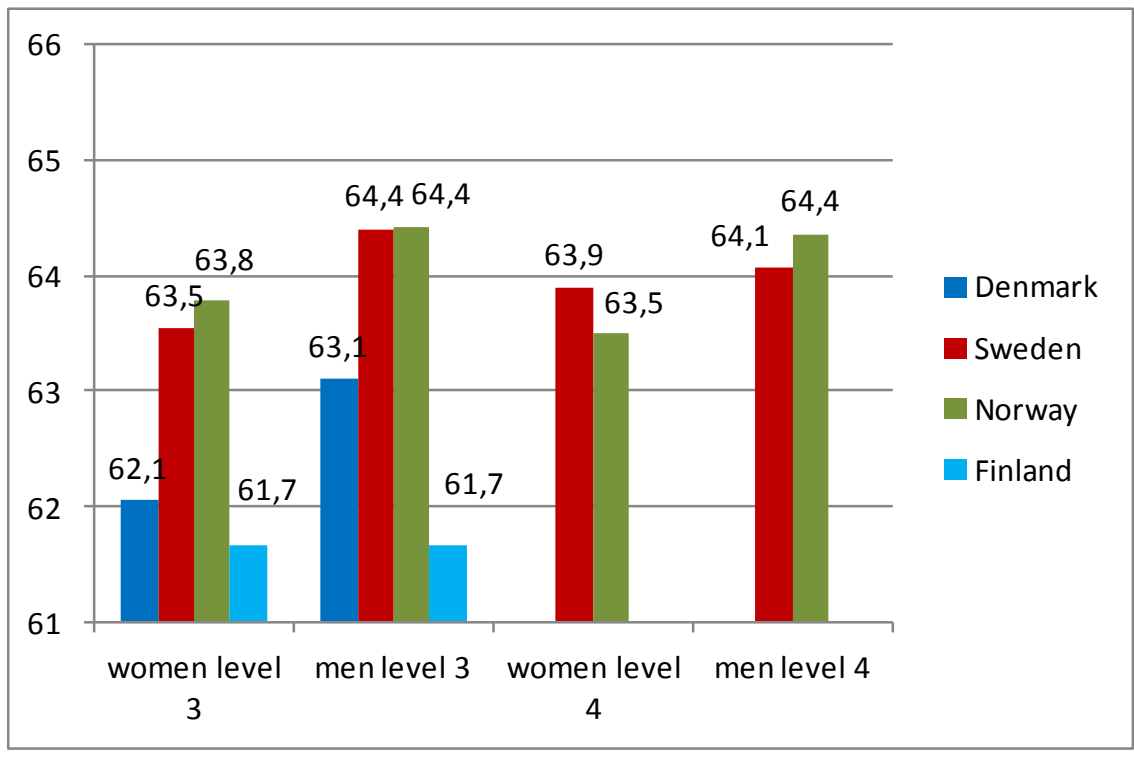

${ }^{1}$ For Denmark, level 3 and 4 are combined and shown in level 3. In Finland, the level-4 educated group is small and the number of retirees in 2009 were too few to calculated a mean retirement age. Source: Statistics Denmark, Sweden, Norway and Finland.

Figure 11. Mean age at retirement in 2009, ISCED level 5-6

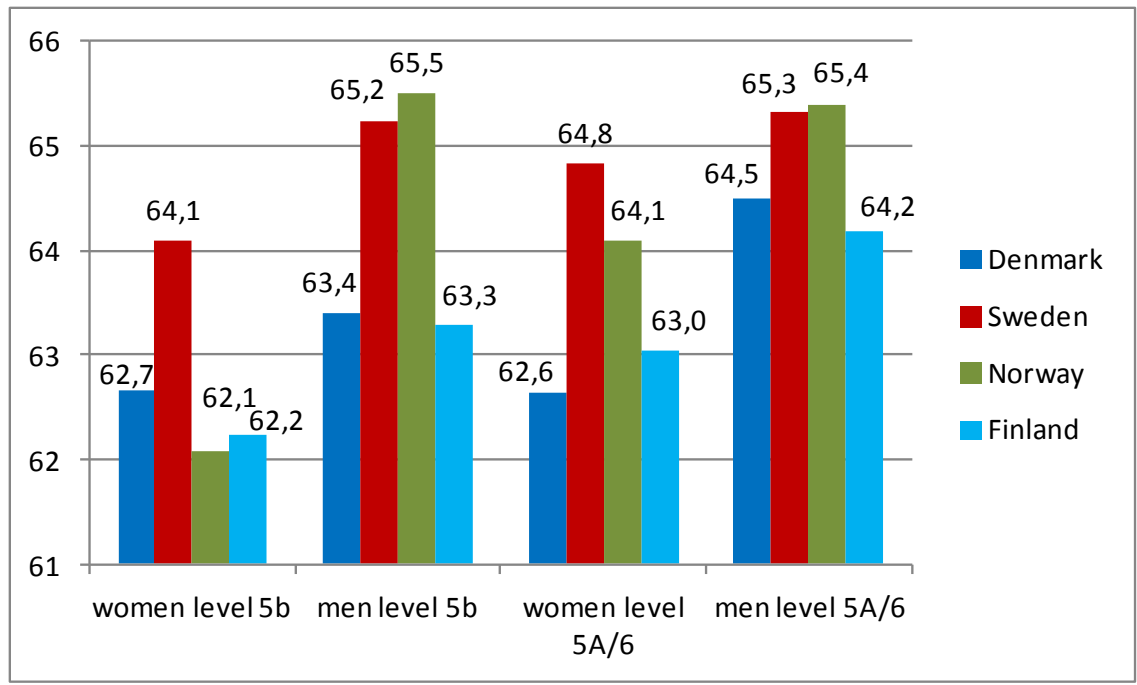

Source: Statistics Denmark, Sweden, Norway and Finland. 


\subsection{Average age at retirement by fields of education, secondary level}

Persons with a secondary-level education make up a large portion of the workforce, ranging from 40 percent of all persons with employment income in 2009 in Finland to 47 percent in Sweden. The median age of employed, ISCED level 3-educated people is about the same as persons at other levels of education, at 41 in Sweden and Denmark and 42 in Norway. In Finland this group is slightly younger than average, with a median age of 38 compared to 41 among employed people overall.

The ISCED level 3-educated population with employment income is distributed unevenly between the eight one-digit ISCED fields of study. The largest field of study at this level is Engineering, manufacturing and construction (field 5). Persons with this field comprised, on average in countries, one in three secondary-educated persons age 50-74 with employment income in 2008.

Social science, business and law (field 3) is also a common field of study, on average 22 percent of a country's employed, secondaryeducated 50-74 year-olds in 2008. This field is especially large in Denmark, at 37 percent, and comparatively small in Finland at 10 percent. The field General programmes (field 0 ) includes, on average in countries, 12 percent of employed age 50-74 at ISCED level 3, although the group is smaller in Denmark, at 3 percent, and larger in Norway, at 26 percent. Other common fields of study include Health and welfare (field 7) and Services (field 8), at 14 percent and 11 percent of employed, secondaryeducated age 50-74, respectively. A list of ISCED levels and fields is included in appendix 2.

In Nordic countries on average, 50-74 year-olds are less likely than employed persons overall to have field General studies, and more likely to have field Social science, business and law or Health and welfare. Otherwise, the distribution of fields of education among employed 50-74 year-olds is similar to that of employed persons overall. 
Table 7. Distribution of ISCED fields of education among employed persons age 50-74, 2008, ISCED level $3^{1}$. Percent

\begin{tabular}{lrrrrrrrrrrr}
\hline ISCED 1997 field of education & $\mathbf{0}$ & $\mathbf{1}$ & $\mathbf{2}$ & $\mathbf{3}$ & $\mathbf{4}$ & $\mathbf{5}$ & $\mathbf{6}$ & $\mathbf{7}$ & $\mathbf{8}$ & $\begin{array}{r}\text { Total level } \\
\mathbf{3}^{\mathbf{2}}\end{array}$ \\
& & & & & & & & & & & \\
Denmark & 3 &.. & 4 & 37 & 2 & 35 & 3 & 11 & 5 & 100 \\
Sweden & 11 & 0.16 & 1 & 22 & 1 & 33 & 2 & 18 & 9 & 100 \\
Norway & 26 & 0.21 & 3 & 20 & 3 & 23 & 3 & 12 & 10 & 100 \\
Finland & 7 & 0.15 & 2 & 10 & 1 & 41 & 5 & 14 & 19 & 100 \\
country average & 12 & 0.18 & 2 & 22 & 2 & 33 & 3 & 14 & 11 & 100 \\
\hline
\end{tabular}

${ }^{1}$ Includes levels 3 and 4 for Denmark.

${ }^{2}$ Includes "unknown" field.

ISCED fields of education.

0 General programmes.

1 Education.

2 Humanities and Arts.

3 Social sciences, business and law.

4 Science, Mathematics and Computing.

5 Engineering, manufacturing and construction.

6 Agriculture.

7 Health and welfare.

8 Services.

Source: Statistics Denmark, Sweden, Norway and Finland

Note about ISCED 1: ISCED field 1, Education, is uncommon at the secondary level in Nordic countries, at 0.21 percent or less of employed, secondary-educated 50-74 year-olds in 2008. This field is generally used to categorise teacher's education, which today are largely at the tertiary level. There are only a few thousand persons classified as secondary-educated with the field Education across the Nordic countries, and fewer than a hundred were classified as having retired in 2009. Consequently, mean retirement and retirement projections are not presented for this field.

Table 8. Retirements in 2009 by field of education, ISCED level $3^{1}$. Percent of persons who were age 50-74 and employed in 2008 and registered residents in 2008 and 2009

\begin{tabular}{lrrrrrrrrrr}
\hline $\begin{array}{l}\text { ISCED 1997 field of } \\
\text { education }\end{array}$ & $\mathbf{0}$ & $\mathbf{1}$ & $\mathbf{2}$ & $\mathbf{3}$ & $\mathbf{4}$ & $\mathbf{5}$ & $\mathbf{6}$ & $\mathbf{7}$ & $\mathbf{8}$ & Total level 3 $^{\mathbf{2}}$ \\
\hline Denmark & 4.7 &.. & 5.4 & 6.5 & 2.1 & 6 & 3.7 & 5.2 & 5.7 & 5.9 \\
Sweden & 3.1 & 3.1 & 5.6 & 5.4 & 4.1 & 5.4 & 5.5 & 5.4 & 6.3 & 5.2 \\
Norway & 4.2 & 4.9 & 4.4 & 3.9 & 5 & 3.4 & 4.4 & 2.8 & 4.9 & 3.9 \\
Finland & 3.8 & 4.1 & 4.3 & 5.1 & 2.9 & 5.2 & 8.3 & 3.9 & 5.1 & 5 \\
country average & 3.9 & 4 & 4.9 & 5.2 & 3.5 & 5 & 5.5 & 4.3 & 5.5 & 5 \\
did not retire & 96.1 & 96 & 95.1 & 94.8 & 96.5 & 95 & 94.5 & 95.7 & 94.5 & 95 \\
\hline
\end{tabular}

${ }^{1}$ Includes levels 3 and 4 for Denmark.

"Includes"unknown" level.

Source: Statistics Denmark, Sweden, Norway and Finland. 
In countries on average, five percent of secondary-educated persons who were age 50-74 and had income from employment in 2008 retired in 2009. The percentage of retirees was highest in Denmark and Sweden, at 5.9 percent, and lowest in Norway, at 3.9 percent. The gender distribution among ISCED level 3-educated retirements in 2009 was even overall. However, fields which have high proportions of either men of women among employed also showed high percentages among retired.

Table 9. Percent women among persons who retired in 2009, by field of education, ISCED level $3^{1}$

\begin{tabular}{lccccccccc}
\hline ISCED 1997 field of education & $\mathbf{0}$ & $\mathbf{2}$ & $\mathbf{3}$ & $\mathbf{4}$ & $\mathbf{5}$ & $\mathbf{6}$ & $\mathbf{7}$ & $\mathbf{8}$ & Total level 3 $^{\mathbf{1}}$ \\
\hline Denmark & 52 & 26 & 65 & 21 & 10 & 8 & 95 & 55 & 45 \\
Sweden & 64 & 34 & 76 & 74 & 10 & 11 & 95 & 66 & 53 \\
Norway & 66 & 57 & 66 & 16 & 7 & 8 & 97 & 50 & 50 \\
Finland & 61 & 52 & 79 & 50 & 21 & 18 & 94 & 76 & 49 \\
country average & 60 & 42 & 72 & 41 & 12 & 11 & 95 & 62 & 49 \\
\hline
\end{tabular}

Results are based on persons who had employment income and were age 50-74 in 2008, and were registered residents in 2008 and 2009.

${ }^{1}$ Includes levels 3 and 4 for Denmark.

2Includes "unknown" level.

Source: Statistics Denmark, Sweden, Norway and Finland.

It is notable that in 2008, the median age of employed ISCED level 3educated in Norway was higher than in other countries, at 42 years compared to 38 years in Finland and 41 years in Denmark and Sweden. The mean age at retirement, 64.1 years, is also higher in Norway than other countries.

Table 10. Mean age at retirement in 2009 by field of education, ISCED level $3^{1}$

\begin{tabular}{|c|c|c|c|c|c|c|c|c|c|}
\hline ISCED 1997 field of education & 0 & 2 & 3 & 4 & 5 & 6 & 7 & 8 & Total level $3^{1}$ \\
\hline Denmark & 62.8 & 62.8 & 62.8 & 61.0 & 62.8 & 63.0 & 61.5 & 61.8 & 62.6 \\
\hline Sweden & 62.9 & 64.7 & 63.9 & 63.0 & 64.4 & 65.7 & 63.7 & 63.4 & 64.0 \\
\hline Norway & 64.5 & 63.7 & 64.3 & 64.8 & 63.7 & 66.0 & 61.5 & 64.7 & 64.1 \\
\hline Finland & 61.9 & 61.8 & 62.4 & 59.2 & 61.5 & 63.5 & 61.2 & 60.9 & 61.7 \\
\hline country average & 63.0 & 63.3 & 63.3 & 62.0 & 63.1 & 64.6 & 62.0 & 62.7 & 63.1 \\
\hline
\end{tabular}

Results are based on persons who had employment income and were age 50-74 in 2008, and were registered residents in 2008 and 2009.

${ }^{1}$ Includes levels 3 and 4 for Denmark.

2Includes"unknown" level.

Source: Statistics Denmark, Sweden, Norway and Finland.

\section{ISCED Level 3, field 0: General Programmes}

The General Programmes field includes Basic programmes, Literacy and numeracy and Personal skills. European countries classify a broad range of secondary-level educational programs in this field. On average in countries, one in five employed persons who has completed secondary 
education has this field, although the field is less common among 50-74 year-olds, at 12 percent. The field is less common than average in Denmark, at three percent of employed in 2009, and more common in Norway, at 26 percent. Men are slightly underrepresented in this group except for in Finland, where the gender distribution is even.

On average in countries, the mean age at retirement in 2009 among secondary-educated persons with field General Programmes at level 3 was 63.0 years, similar to the average retirement age of 63.1 years among ISCED level 3-educated overall. Retirement age was highest in Norway, at 64.5 years, and lowest in Finland, at 61.9 years. In most fields, men retire at a higher average age than women. However, in Denmark men in this group retired 0.6 years younger than women. Notably, both men and women among Denmark's employed 50-74 yearolds within General Programmes at level 3 had a median age of 57, and men comprised 54 percent of this group.

Figure 12. Mean age at retirement in 2009, ISCED level 3, field 0: General Programmes

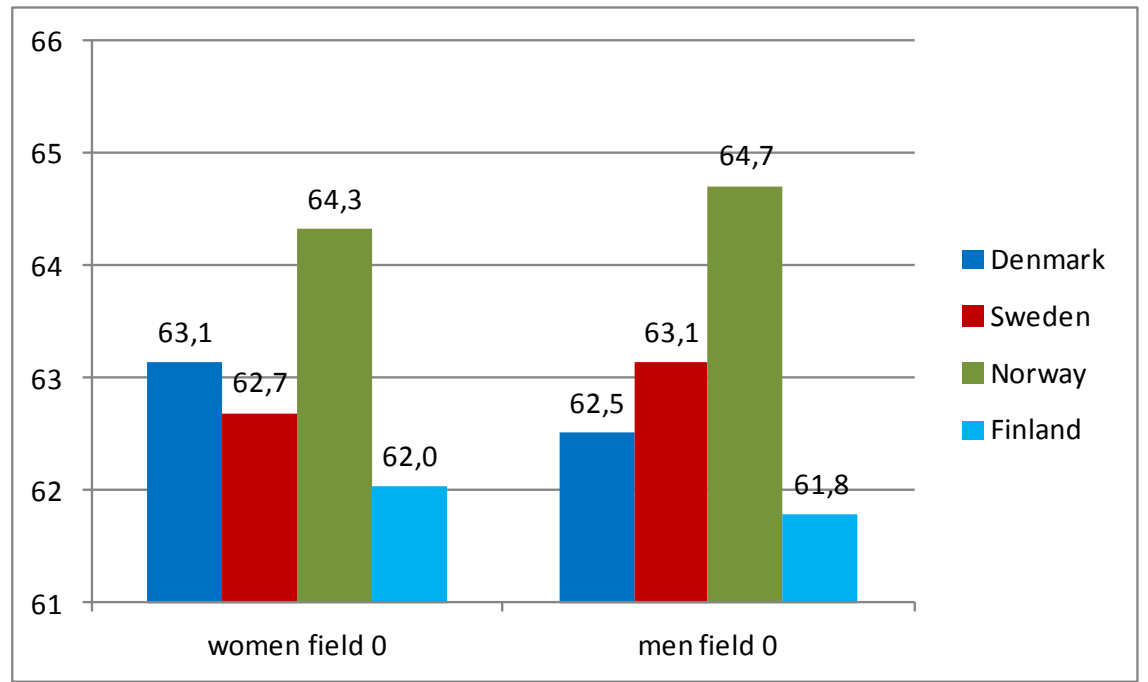

Source: Statistics Denmark, Sweden, Norway and Finland.

ISCED Level 3, field 2: Humanities and Arts

The Humanities and Arts field includes programmes in fine arts, music, media production, design, crafts, humanities, language, history, religion and philosophy. The field covers a wide range of educational programmes and is less common among older persons than younger, comprising, on average, two percent of a country's employed, secondary-educated population age 50-74 in 2008. In Denmark, the percentage is slightly higher, at four per- 
cent, and in Finland lower, at one percent. As with General Programmes, men are underrepresented in Humanities and Arts at level 3, especially in Norway where they comprised just 31 percent this group in 2008. For comparison, in all four countries in 2008 men made up 47 percent of the employed ISCED level 3-educated population overall.

In Humanities and Arts at ISCED level 3, the average age at retirement in 2009 in a country was 63.3 years, compared to 63.1 years for employed ISCED level 3-educated persons overall. Men in this group retired at a higher age than women in all countries, although in Finland the difference was less than half a year. Norway and Sweden had especially high retirement ages among men in this group, at 65.0 years and 65.3 years, respectively.

In Sweden in 2009, two of three retirees in this educational group were men, and in Denmark three of four were men. Although men are underrepresented among employed persons in this educational group overall, they comprised the majority among 50-74 year-olds in Sweden and Denmark. The gender distribution is roughly even in Finland and Norway.

Figure 13. Mean age at retirement in 2009, ISCED level 3, field 2: Humanities and Arts

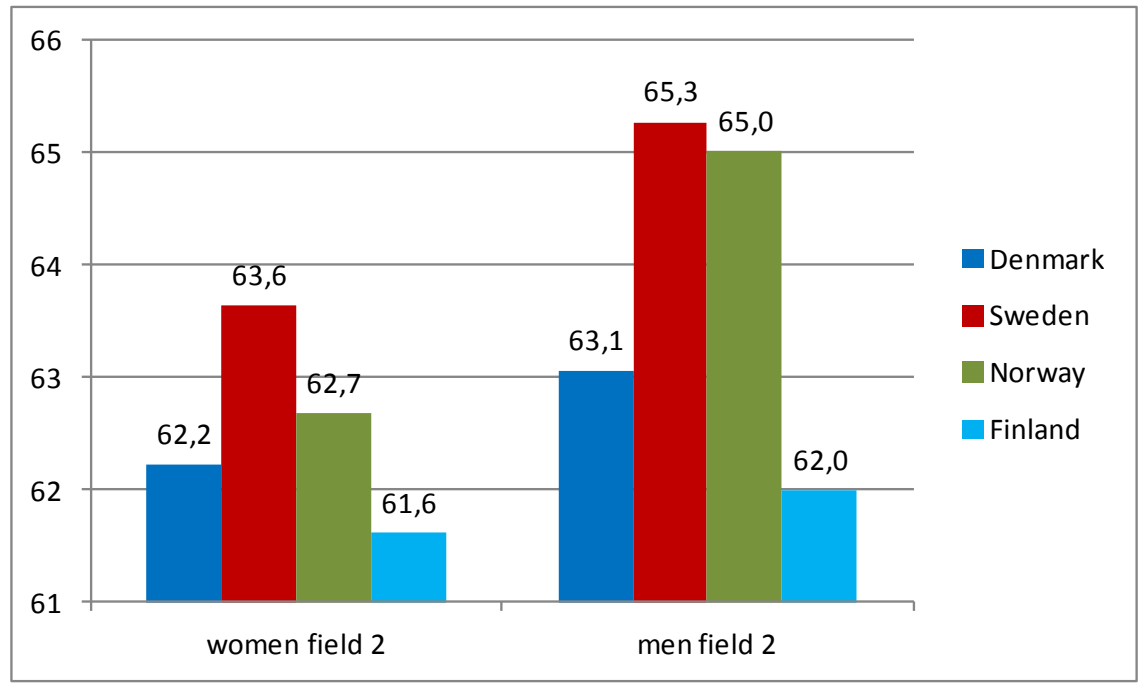

Source: Statistics Denmark, Sweden, Norway and Finland.

\section{ISCED Level 3, field 3: Social sciences, Business and Law}

The field Social sciences, Business and Law includes programmes in Social and behavioural science, Journalism and information, Business and administration, and Law. This is a large group, comprising an average of 22 percent of a country's employed, ISCED level 3-educated 50-74 year- 
olds in 2008. The group is especially large Denmark, at 37 percent of employed age 50-74, and is smaller in Finland, at 10 percent.

Two-thirds of employed persons age 50-74 in 2008 with a secondary education within Social sciences, Business and Law were women. Women are overrepresented in all countries in this educational group and among the subset of 50-74 year-olds, as well. In Norway and Denmark, two of three retirees in 2009 from this group were women, and in Sweden and Finland three of four were women.

Within Social sciences, Business and Law at level 3, the average age at retirement in 2009 in Nordic countries was 63.3 years, compared to 63.1 years for employed ISCED level3-educated persons overall. Sweden and Norway had the highest mean retirement age, at 63.9 and 64.3 years, respectively. Men in this group retired at a higher age than women in all countries.

Figure 14. Mean age at retirement in 2009, ISCED level 3, field 3: Social sciences, Business and Law

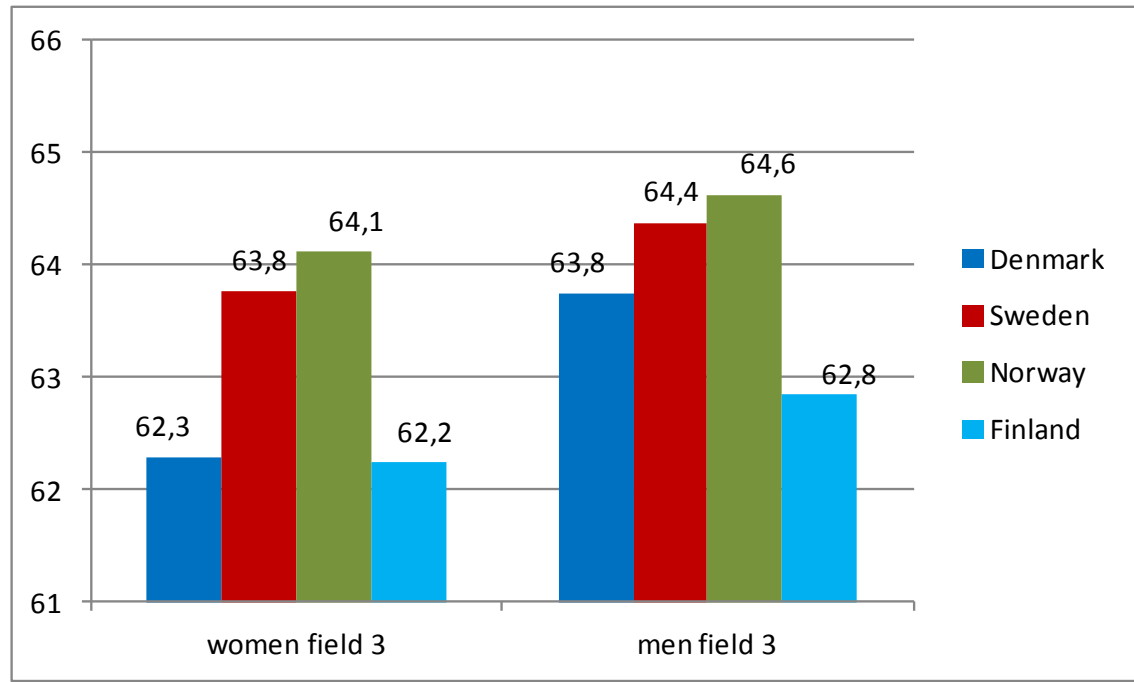

Source: Statistics Denmark, Sweden, Norway and Finland.

\section{ISCED Level 3, field 4: Science, Mathematics and Computing}

The field of education Science, Mathematics and Computing includes secondary programmes in Life science, Physical science, and Mathematics and statistics. In 2009, this group comprised three percent or fewer of all employed secondary-educated 50-74 year-olds in each country. In Sweden the gender distribution in this group is even; in other countries six of ten or more of this group are men. 
Among 50-74 year-olds in this educational group in Sweden, however, the majority are women, and women made up three of four retirees in 2009. In Denmark and Norway, more than three of four retirees from this group were men.

Within the field Science at ISCED level 3, the average age at retirement in 2009 in Nordic countries was 62,0 years, compared to 63,1 years for employed ISCED level3-educated persons overall. Men in this group retired at a higher age than women in Denmark, Sweden and Norway. In Norway the difference between men and women was 1.7 years, compared to 1.0 years in Sweden and 0.5 years in Denmark.

Figure 15. Mean age at retirement in 2009, ISCED level 3, field 4: Science, Mathematics and Computing

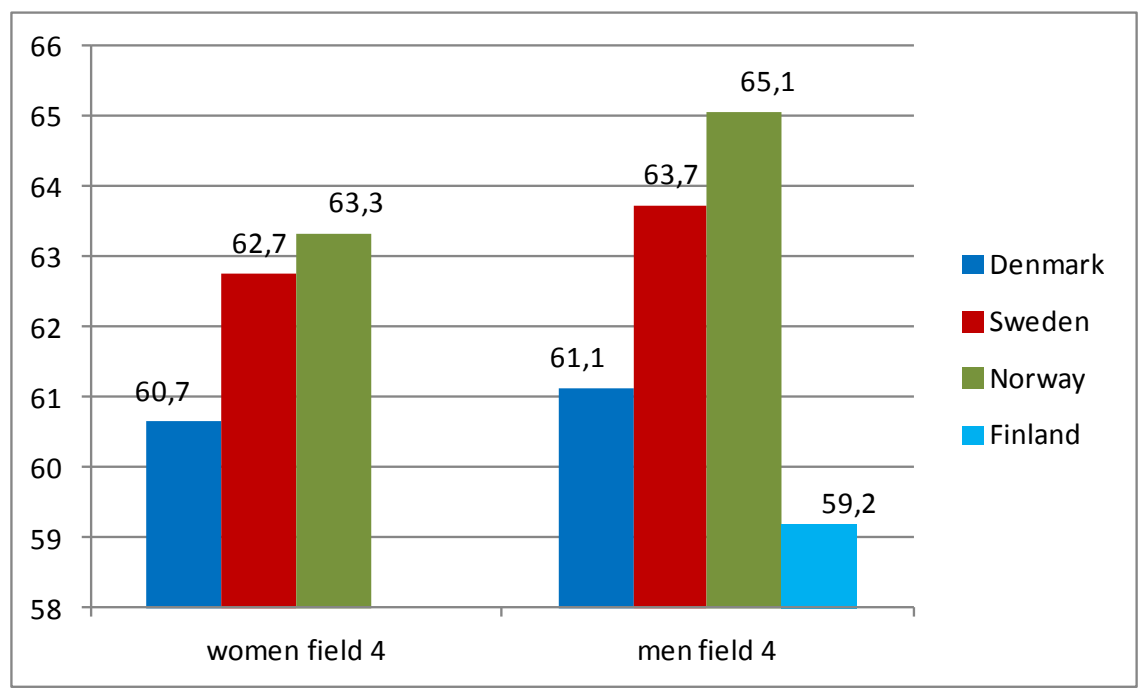

For Finland, the bar shows men+women.

Source: Statistics Denmark, Sweden, Norway and Finland.

ISCED Level 3, field 5: Engineering, Manufacturing and Construction

The field Engineering, Manufacturing and Construction includes programmes in Engineering and engineering trades, Manufacturing and processing and Architecture and building. Secondary-level programmes in this group include industrial and technical vocational studies as well as programmes that prepare for higher education. This is a large group, comprising in countries in 2008 between 23 and 41 percent of employed persons age 50-74 whose highest level of education is at the secondary level.

Nine of ten persons in this group are men, and nine of ten retirees in 2009 were men also. In Finland, the percentage of women among retirees was higher, at 21 percent, reflecting that country's higher-than-average proportion of women among 50-74 year-olds in this educational group. 
Within the field Engineering, Manufacturing and Construction at ISCED level 3, the average age at retirement in 2009 in Nordic countries was 63.1 years, the same as for employed ISCED level3-educated persons overall. Men in this group retired at a higher age than women in Denmark, Sweden and Norway. In Finland, men who retired from this group were 0.6 years younger than women.

Figure 16. Mean age at retirement in 2009, ISCED level 3, field 5: Engineering, Manufacturing and Construction

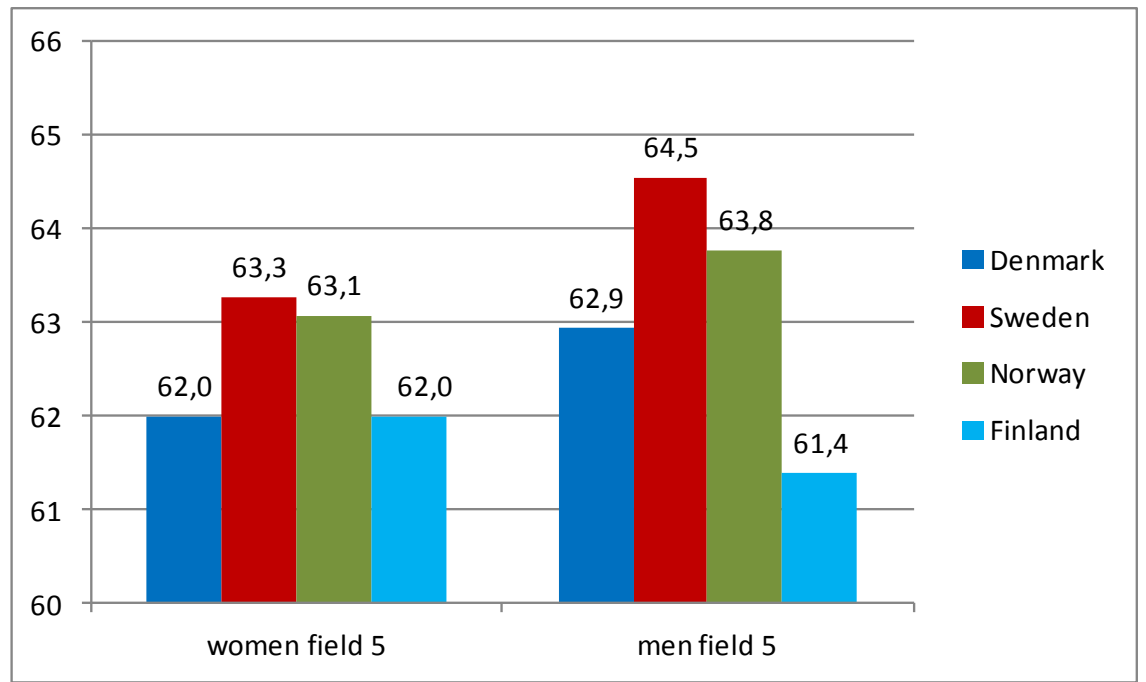

Source: Statistics Denmark, Sweden, Norway and Finland.

\section{ISCED Level 3, field 6: Agriculture and Veterinary}

The field Agriculture and Veterinary includes programmes in agriculture, forestry, fisheries, crop and livestock production, horticulture, and veterinary science. This group comprised about three percent of employed persons in 2008 whose highest education was at the secondary level. The majority of this group are men - two of three in Sweden and Finland and three of four in Norway and Denmark.

The 50-74 year-old portion of this group has an even higher representation of men, at roughly four of five in Sweden and Finland and nine of ten in Norway and Denmark. Accordingly, only a minority of retirees from this group in 2009 were women, at one in ten in Sweden, Denmark and Norway, although the proportion of women was higher in Finland, at one in five.

In 2009, the mean age at retirement within the field Agriculture and veterinary at ISCED level 3 was 64.6 years, higher than all other fields of education at this level. In Sweden and Norway the retirement age was 
especially high, at 65.7 years and 66.0 years, respectively. Men retired on average 3.0 years older than women, consistent with men's' higher median age among 50-74 year-olds in this educational group.

Figure 17. Mean age at retirement in 2009, ISCED level 3, field 6: Agriculture and Veterinary

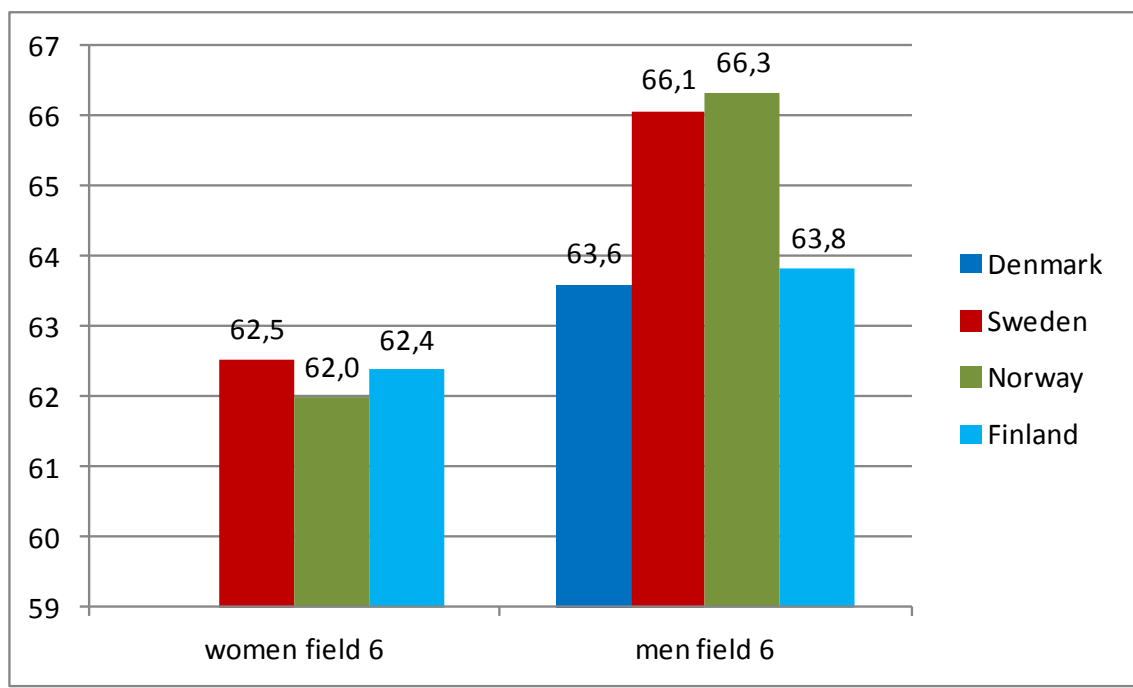

Source: Statistics Denmark, Sweden, Norway and Finland.

\section{ISCED Level 3, field 7: Health and Welfare}

The field Health and Welfare at the secondary level includes programmes in nursing, dental hygiene, medical technology, therapy and rehabilitation, pharmacy, childcare and social work. In 2008, this group comprised 18 percent of the employed secondary-educated persons age 50-74 in Sweden, compared to 14 percent in Finland, 12 percent in Norway and 11 percent in Denmark. In all countries, more than nine of ten in this group are women. 
Figure 18. Mean age at retirement in 2009, ISCED level 3, field 7: Health and Welfare

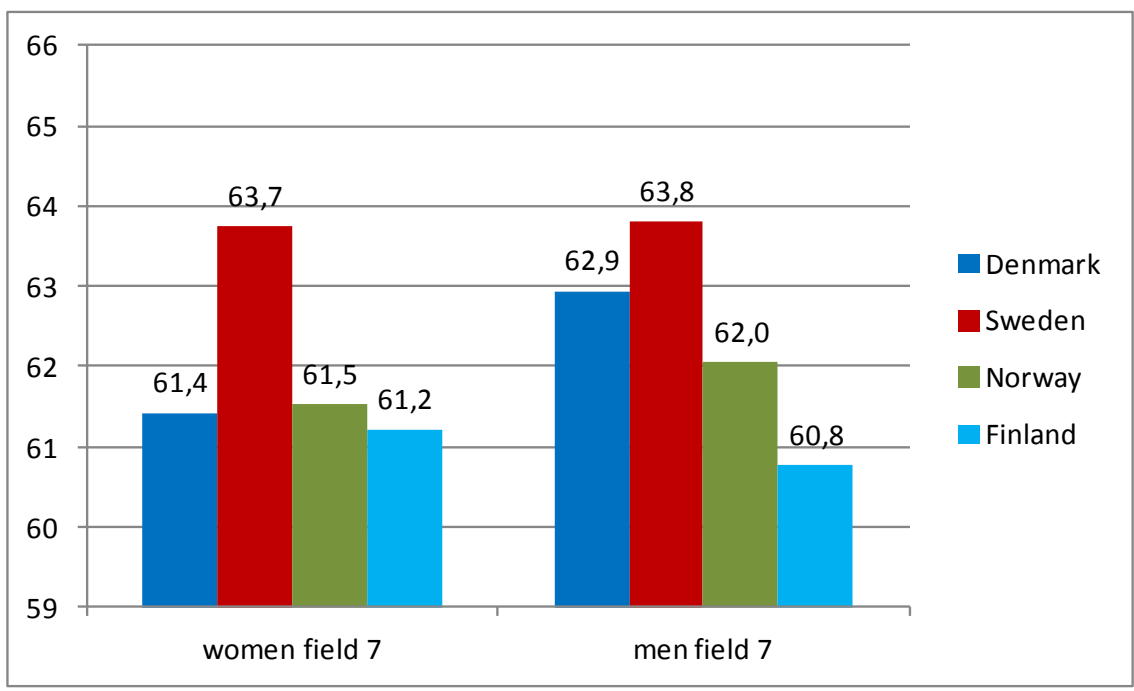

Source: Statistics Denmark, Sweden, Norway and Finland.

The median age of this group is 44 , several years higher than the median age of employed, secondary-educated persons overall. This difference is seen in all four countries. 50-74 year-olds make up a considerably larger fraction of the total employed persons with the field Health and Welfare than they do of other fields at the secondary level.

Consistent with their overrepresentation here, women made up the bulk of retirements in 2009 from this group - 94 percent in Finland and even higher percentages in other countries.

In 2009, the mean age at retirement within the field Health and Welfare at ISCED level 3 was 62.0 years, 1.1 years younger than average for secondary-educated. Notably, in Sweden the mean retirement age was more than two years higher than in other countries.

\section{ISCED Level 3, field 8: Services}

The field Services includes programmes in personal services, hotel and restaurant, travel, tourism, sports, transport, hair and beauty, domestic services, as well as fire fighting, occupational safety and certain military studies. This size of the group varies in the four countries from 19 percent of employed, secondary-educated 50-74 year-olds in Finland to 10 percent in Norway, 9 percent in Sweden and 5 percent in Denmark. The distribution of men and women in this group is roughly even, except for in Finland where in 2008 women comprised 71 percent of all employed age 50-74 and 80 percent of those age 50-74. 
Figure 19. Mean age at retirement in 2009, ISCED level 3, field 7: Health and welfare

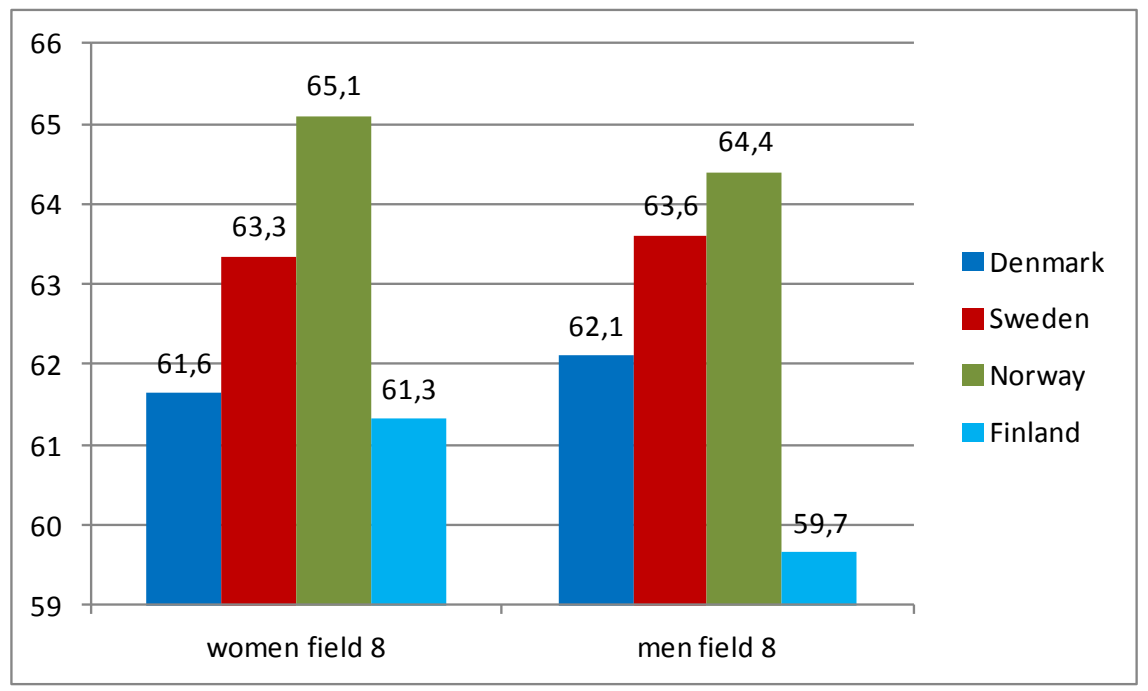

Source: Statistics Denmark, Sweden, Norway and Finland.

Accordingly, in Finland in 2009 women made up three fourths of all retirements from the previous years' group of employed, secondaryeducated 50-74 year-olds with the field of education Services. In Sweden, two of three retirements in this group were women, and in Denmark the proportions of men and women were roughly equal.

In 2009, the mean age at retirement within the field Services at ISCED level 3 was 62.7 years, 0.4 years younger than average for secondaryeducated.

\subsection{Average age at retirement by fields of education, post-secondary level}

Persons who have completed education beyond the secondary level comprised a third of all employed persons in Nordic countries in 2009, and the proportion is similar in all countries. Most of these employed persons have some form of tertiary education, i.e. at ISCED levels 5 and 6. A minority have completed a post-secondary, non-tertiary education at level 4, including seven percent in Sweden, three percent in Norway and one percent in Finland.

In Nordic countries, the most common fields of study among employed persons with a tertiary-level education are Health (72), Business and administration (34), Teacher training and education science (14) and Engineering and engineering trades (52). These four fields together com- 
prised six of ten employed persons age 50-74 in 2008 with ISCED level 4-6 education. Other fields of study that comprised five percent or more of all post-secondary educated, employed 50-74 year-olds in 2008 include Social services (76), Humanities (22), Social and behaviour science (31), and Architecture and building (58).

In Finland, the field Teacher training and education science is less common than in other countries, at seven percent of employed age 5074. Teachers in Finland commonly have a field of education corresponding to the subject matter they teach. However, the field Business and administration is twice as common in Finland as in other countries, comprising 26 percent of employed 50-74 year-olds with a postsecondary education in 2008.

It should be noted that educational systems and their correspondence to specific occupations in the labour market are unique in each country. Finland, for example, prepares persons to be teachers differently than Sweden does. This uniqueness explains much of the differences in the distribution of fields of study. Further, countries vary somewhat in how they apply the ISCED system, especially ISCED levels 4 and 5B.

For this reason, the analysis here based on fields of education includes all persons with an education beyond the secondary level, i.e. those whose who have completed programmes classified as ISCED levels 4, 5b, 5A, or 6 in Sweden, Norway and Finland. For Denmark, analysis of fields includes only ISCED levels 5A and 6. In Denmark the ISCED level 4educated group is small and is generally grouped with ISCED 3.

Regarding ISCED level 4, this group comprises 5 percent of secondary-educated age 50-74 in Sweden and less in other countries. For most fields of study shown in this section, educational programs are at the tertiary level. 
Table 11. Distribution of ISCED fields of education among employed persons age 50-74, 2008, ISCED level $4-6^{1}$. Percent

\begin{tabular}{|c|c|c|c|c|c|c|}
\hline & & Denmark & Sweden & Norway & Finland & $\begin{array}{r}\text { country } \\
\text { mean }\end{array}$ \\
\hline & ISCED field of education & & & & & \\
\hline 14 & Teacher training and education & 20 & 26 & 23 & 7 & 19 \\
\hline 21 & Arts & 1 & 1 & 1 & 1 & 1 \\
\hline 22 & Humanities & 7 & 4 & 6 & 6 & 6 \\
\hline 2 & Humanities and Arts & 8 & 5 & 7 & 7 & 7 \\
\hline 31 & Social and behavioural science & 4 & 6 & 6 & 5 & 5 \\
\hline 32 & Journalism and information & 2 & 1 & $<1$ & $<1$ & 1 \\
\hline 34 & Business and administration & 6 & 10 & 10 & 26 & 13 \\
\hline 38 & Law & 3 & 2 & 2 & 2 & 2 \\
\hline 3 & Social Sciences, Business and Law & 15 & 20 & 19 & 33 & 22 \\
\hline 42 & Life sciences & $<1$ & $<1$ & $<1$ & $<1$ & $<1$ \\
\hline 44 & Physical sciences & 1 & $<1$ & 1 & 2 & 1 \\
\hline 46 & Mathematics and statistics & $<1$ & 2 & $<1$ & 1 & $<1$ \\
\hline 48 & Computing & $<1$ & 1 & $<1$ & 1 & $<1$ \\
\hline 4 & Science, Mathematics and Computing & 3 & 4 & 3 & 5 & 4 \\
\hline 52 & Engineering and engineering trades & 7 & 11 & 11 & 15 & 11 \\
\hline 54 & Manufacturing and processing & $<1$ & $<1$ & $<1$ & 2 & $<1$ \\
\hline 58 & Architecture and building & 6 & 2 & 5 & 6 & 5 \\
\hline 5 & Engineering, Manufacturing and Construction & 13 & 14 & 16 & 24 & 17 \\
\hline 62 & Agriculture, forestry and fish & $<1$ & 1 & $<1$ & 3 & 1 \\
\hline 64 & Veterinary & $<1$ & $<1$ & $<1$ & $<1$ & $<1$ \\
\hline 6 & Agriculture and Veterinary & 1 & 1 & 1 & 3 & 2 \\
\hline 72 & Health & 20 & 19 & 17 & 15 & 18 \\
\hline 76 & Social services & 19 & 5 & 2 & 2 & 7 \\
\hline 7 & Health and Welfare & 39 & 24 & 19 & 16 & 24 \\
\hline 81 & Personal services & $<1$ & $<1$ & $<1$ & 2 & $<1$ \\
\hline 84 & Transport services & $<1$ & $<1$ & 1 & $<1$ & $<1$ \\
\hline 85 & Environmental protection & $<1$ & $<1$ & $<1$ & $<1$ & $<1$ \\
\hline 86 & Security services & $<1$ & 3 & 1 & 1 & 2 \\
\hline 8 & Services & 1 & 4 & 3 & 4 & 3 \\
\hline \multirow[t]{3}{*}{99} & Other/not known & $<1$ & $<1$ & 8 & $<1$ & 3 \\
\hline & total (\%) & 100 & 100 & 100 & 100 & 100 \\
\hline & total $(000)$ & 223 & 537 & 268 & 305 & 1,333 \\
\hline
\end{tabular}

${ }^{1}$ Includes only levels $5 \mathrm{~A}$ and 6 for Denmark.

"Field 99 includes "other" and "unknown" fields.

Source: Statistics Denmark, Sweden, Norway and Finland.

Overall in Nordic countries, retirements in 2009 amounted to 3.9 percent of 50-74 year-olds with a post-secondary education who were employed in 2008. The percentage of retirees was highest in Denmark and Finland, at 4.3 percent, and lowest in Norway, at 2.7 percent.

Field of education Teacher training (ISCED 14) made up the single largest group of retirements in 2009, at 24 percent of the total at this educational level. Each of the fields Health, Business and Administration and Engineering and engineering trades each comprised ten percent or more of total retirements. 
Table 12. Retirements in 2009 among persons age who were age 50-74 and employed in 2008, ISCED level 4-61. Percent

\begin{tabular}{|c|c|c|c|c|c|c|}
\hline & & Denmark & Sweden & Norway & Finland & $\begin{array}{l}\text { country } \\
\text { mean }\end{array}$ \\
\hline & ISCED field of education & & & & & \\
\hline 14 & Teacher training and education & 6.3 & 4.7 & 3.1 & 5.3 & 4.9 \\
\hline 21 & Arts & 2.4 & 4.7 & 2.1 & 3.3 & 3.1 \\
\hline 22 & Humanities & 3.2 & 4.8 & 2.6 & 5.3 & 4.0 \\
\hline 31 & Social and behavioural science & 2.3 & 4.9 & 2.0 & 4.5 & 3.4 \\
\hline 32 & Journalism and information & 4.0 & 3.8 & 2.2 & 5.0 & 3.7 \\
\hline 34 & Business and administration & 3.5 & 4.5 & 2.4 & 3.8 & 3.5 \\
\hline 38 & Law & 3.6 & 3.3 & 2.1 & 4.1 & 3.3 \\
\hline 42 & Life sciences & $<1$ & 3.2 & 1.5 & 4.3 & 2.2 \\
\hline 44 & Physical sciences & 3.3 & 3.7 & 2.7 & 4.4 & 3.5 \\
\hline 46 & Mathematics and statistics & 2.3 & 5.3 & 4.2 & 6.0 & 4.5 \\
\hline 48 & Computing & $<1$ & 3.0 & 1.0 & 1.9 & 1.5 \\
\hline 52 & Engineering and engineering trades & 4.5 & 2.8 & 3.1 & 4.1 & 3.6 \\
\hline 54 & Manufacturing and processing & $<1$ & 3.5 & 1.3 & 5.6 & 2.6 \\
\hline 58 & Architecture and building & 4.0 & 3.0 & 1.9 & 4.4 & 3.4 \\
\hline 62 & Agriculture, forestry and fish & 4.3 & 3.9 & 2.3 & 6.2 & 4.2 \\
\hline 64 & Veterinary & 3.3 & 2.5 & 1.9 & 4.1 & 2.9 \\
\hline 72 & Health & 3.8 & 3.4 & 2.6 & 4.1 & 3.5 \\
\hline 76 & Social services & 4.4 & 3.5 & 2.0 & 2.9 & 3.2 \\
\hline 81 & Personal services & $<1$ & 2.0 & 1.8 & 2.4 & 1.6 \\
\hline 84 & Transport services & 5.3 & 7.1 & 5.1 & 9.1 & 6.7 \\
\hline 85 & Environmental protection & $<1$ & 3.2 & 0.9 & 2.5 & 1.6 \\
\hline 86 & Security services & 6.2 & 5.9 & 3.0 & 9.2 & 6.1 \\
\hline \multirow[t]{3}{*}{99} & Other/not known2 & $<1$ & 4.1 & 3.3 & 0.7 & 2.7 \\
\hline & total & 4.3 & 4.1 & 2.7 & 4.3 & 3.5 \\
\hline & Did not retire & 95.7 & 95.9 & 97.3 & 95.7 & 96.1 \\
\hline
\end{tabular}

${ }^{1}$ Includes only levels $5 A$ and 6 for Denmark.

${ }^{2}$ Field 99 includes "other" and "unknown" fields.

Source: Statistics Denmark, Sweden, Norway and Finland.

On average in Nordic countries in 2009, the mean age at retirement for persons with an ISCED level 4-6 education who were age 50-74 and employed in 2008 was 64.0 years. Sweden and Norway had relatively high mean retirement ages compared to Denmark and Finland, although not for all fields of education. 
Table 13. Mean age at retirement in 2009 by field of education, ISCED level $4-6^{1}$

\begin{tabular}{|c|c|c|c|c|c|c|}
\hline & & Denmark & Sweden & Norway & Finland & $\begin{array}{r}\text { country } \\
\text { mean }\end{array}$ \\
\hline & ISCED field of education & & & & & \\
\hline 14 & Teacher training and education & 62.8 & 64.9 & 64.5 & 63.4 & 63.9 \\
\hline 21 & Arts & 64.5 & 65.8 & 63.6 & 64.5 & 64.6 \\
\hline 22 & Humanities & 65.3 & 65.7 & 65.5 & 63.8 & 65.1 \\
\hline 2 & Humanities an Arts & 65.2 & 65.7 & 65.3 & 63.9 & 65.0 \\
\hline 31 & Social and behavioural science & 64.2 & 64.5 & 64.4 & 63.9 & 64.2 \\
\hline 32 & Journalism and information & 62.9 & 64.8 & 64.1 & 63.2 & 63.8 \\
\hline 34 & Business and administration & 64.4 & 64.8 & 64.4 & 62.3 & 64.0 \\
\hline 38 & Law & 66.0 & 64.8 & 64.3 & 64.1 & 64.8 \\
\hline 3 & Social Sciences, Business and Law & 64.4 & 64.7 & 64.3 & 62.7 & 64.0 \\
\hline 42 & Life sciences & .. & 64.9 & .. & 64.2 & .. \\
\hline 44 & Physical sciences & 66.0 & 65.7 & 65.4 & 64.1 & 65.3 \\
\hline 46 & Mathematics and statistics & 67.3 & 64.6 & .. & 62.6 & 64.9 \\
\hline 48 & Computing & .. & 63.1 & .. & 60.0 & .. \\
\hline 4 & Science, Mathematics and Computing & 66.4 & 64.4 & 65.1 & 63.1 & 64.7 \\
\hline 52 & Engineering and engineering training & 65.4 & 64.2 & 65.4 & 63.4 & 64.6 \\
\hline 54 & Manufacturing and processing & .. & 64.6 & .. & 63.4 & .. \\
\hline 58 & Architecture and building & 65.2 & 65.1 & 65.5 & 64.4 & 65.1 \\
\hline 5 & Engineering, Manufacturing and Construction & 65.3 & 64.4 & 65.4 & 63.7 & 64.7 \\
\hline 62 & Agriculture, forestry and fish & 65.6 & 66.5 & 66.9 & 65.2 & 66.0 \\
\hline 64 & Veterinary & 66.8 & .. & .. &.. & .. \\
\hline 6 & Agriculture and Veterinary & 66.0 & 66.4 & 66.6 & 65.2 & 66.1 \\
\hline 72 & Health & 64.0 & 64.7 & 64.8 & 62.9 & 64.1 \\
\hline 76 & Social services & 61.4 & 64.5 & 62.6 & 62.4 & 62.7 \\
\hline 7 & Health and Welfare & 62.7 & 64.6 & 64.6 & 62.9 & 63.7 \\
\hline 81 & Personal services & .. & .. & .. & 61.4 & .. \\
\hline 84 & Transport services & 65.5 & 64.8 & 65.4 & 62.5 & 64.5 \\
\hline 85 & Environmental protection & .. & .. & .. & .. & .. \\
\hline 86 & Security services & 63.4 & 64.7 & 63.1 & 60.8 & 63.0 \\
\hline \multirow[t]{2}{*}{8} & Services & 64.3 & 64.7 & 64.3 & 61.3 & 63.6 \\
\hline & all fields, level 4+5+61 & 63.5 & 64.8 & 64.7 & 63.2 & 64.0 \\
\hline
\end{tabular}

${ }^{1}$ Includes levels 3 and 4 for Denmark.

${ }^{2}$ Includes "unknown" level.

Source: Statistics Denmark, Sweden, Norway and Finland.

\section{ISCED Level 4-6, field 14: Teacher Training and Education Science}

ISCED field of education 14, Teacher Training and Education Science, includes programmes that train pre-school teachers and teachers at basic levels, teachers with subject specialisation, and teachers of vocational subjects. This is a large group in Scandinavian countries, comprising in 2008 between 20 and 26 percent of employed persons age 50-74 with and ISCED level 4 or higher education in Denmark, Sweden and Norway. In Finland the group is smaller, at seven percent of employed age 50-74 in 2008. Teacher training programmes are largely at the tertiary level, ISCED 5A. 
Figure 20. Mean age at retirement in 2009, ISCED level 4-61, field 14: Teacher training and education science

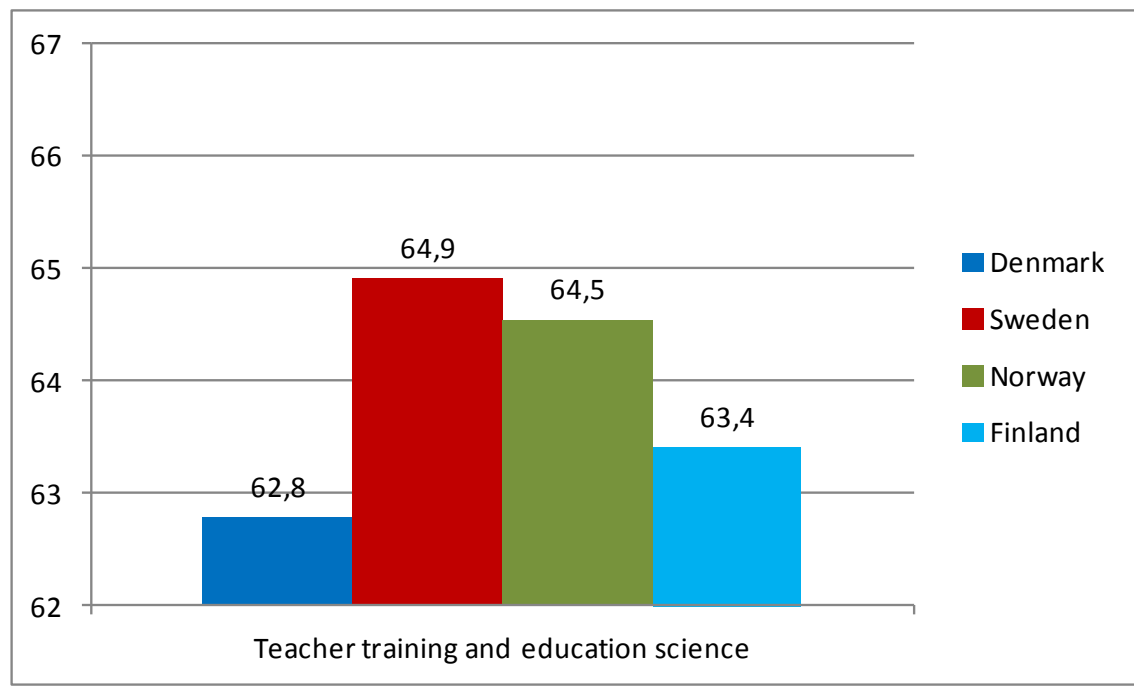

${ }^{1}$ Denmark is based on levels $5 \mathrm{~A} / 6$.

Source: Statistics Denmark, Sweden, Norway and Finland.

This group is older than average for this level of education, with a median age of 45 years in Nordic countries in 2008, compared to 42 years for employed, level ISCED 4-6-educated persons overall. The median age was highest in Denmark, at 47 years, and lowest in Finland, at 44 years. However, the subgroup of 50-74 year-olds has a median age of 57, the same as for ISCED level 4-6-educated persons overall.

In 2009, persons with an ISCED field 14 education made up one in four retirements among post-secondary-educated persons who were employed the previous year. In Sweden and Denmark the proportion was higher, at one in three, and in Finland lower, at one in ten. Among 50-74 year-olds in this group who were employed in 2008, 4.9 percent retired in 2009. Denmark had a higher-than-average level of retirements from this older age group, at 6.3 percent, and Norway lower, at 3.1 percent.

In Nordic countries in 2009, the mean age at retirement among ISCED level 4-6-educated persons with field 14 who were age 50-74 and employed in 2008 was 63.9 years. In Denmark the mean was lowest of the four countries, at 62.8 years, and in Sweden highest, at 64.9 years.

\section{ISCED Level 4-6, field 2: Arts and Humanities}

Field 2 includes two narrow fields: Arts (21) and Humanities (22). Arts includes programmes in fine arts, music and performing arts, audiovisual techniques, media production, design and craft skills. Humanities includes programmes in religion, foreign languages, mother tongue; histo- 
ry and archaeology; and philosophy and ethics. Arts comprised about one percent of employed persons age 50-74 with an ISCED level 4-6 education in 2008, and the field Humanities comprised six percent.

Figure 21. Mean age at retirement in 2009, ISCED level 4-61, field 2: Humanities and arts

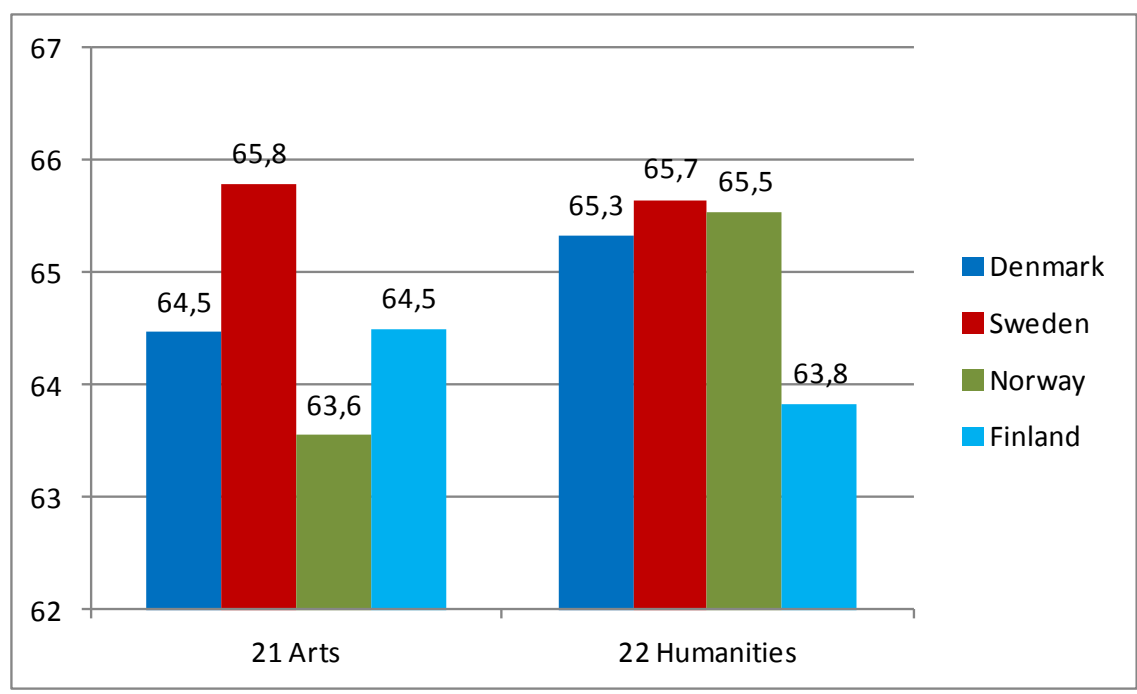

${ }^{1}$ Denmark is based on levels $5 \mathrm{~A} / 6$.

Source: Statistics Denmark, Sweden, Norway and Finland.

With a median age of 35 years, employed persons within the field Arts are a young group in all countries, seven years younger than average for this level of education. In Denmark and Sweden, employed persons within the field Humanities are also young - three to four years younger than average for ISCED level 4-6-educated. In Finland and Norway, employed persons with field Humanities are the same age as average for this educational level, at 43 years and 41 years in those countries, respectively.

Persons with the field Arts made up one percent of all retirements in 2009 among the ISCED level 4-6-educated population who were employed in 2008. Person with the field Humanities made up five percent.

In 2009, tertiary-educated persons within Arts and Humanities retired older than others at this education level. Within Arts, the mean age at retirement in 2009 among was 64.6 years, and within Humanities it was 65.1 years. In Norway, retirement age was lower than other countries for Arts, at 63.6 years. In Finland, persons with field Humanities retired in 2009 at a mean age of 63.8 years, compared to 65.3 years or higher in all other countries. 


\section{ISCED Level 4-6, field 3: Social Sciences, Business and Law}

Field of education 3, Social Sciences, Business and Law, includes the four narrow fields Social and behavioural sciences (31), Journalism and information (32), Business and administration (34), and Law (38). In Nordic countries, persons who have completed such programmes comprised between 15 and 33 percent of employed, ISCED level 4-6-educated 5074 year-olds in 2008. Business and administration is the largest narrow field and is especially large in Finland, at 26 percent of employed 50-74 year-olds at this educational level. Social and behavioural sciences comprised between 4 and 9 percent of employed age 50-74 at this level in 2008, and Journalism and information and Law are smaller groups, at 2 percent or less.

Figure 22. Mean age at retirement in 2009, ISCED level 4-61, field 3: Social Sciences, Business and Law

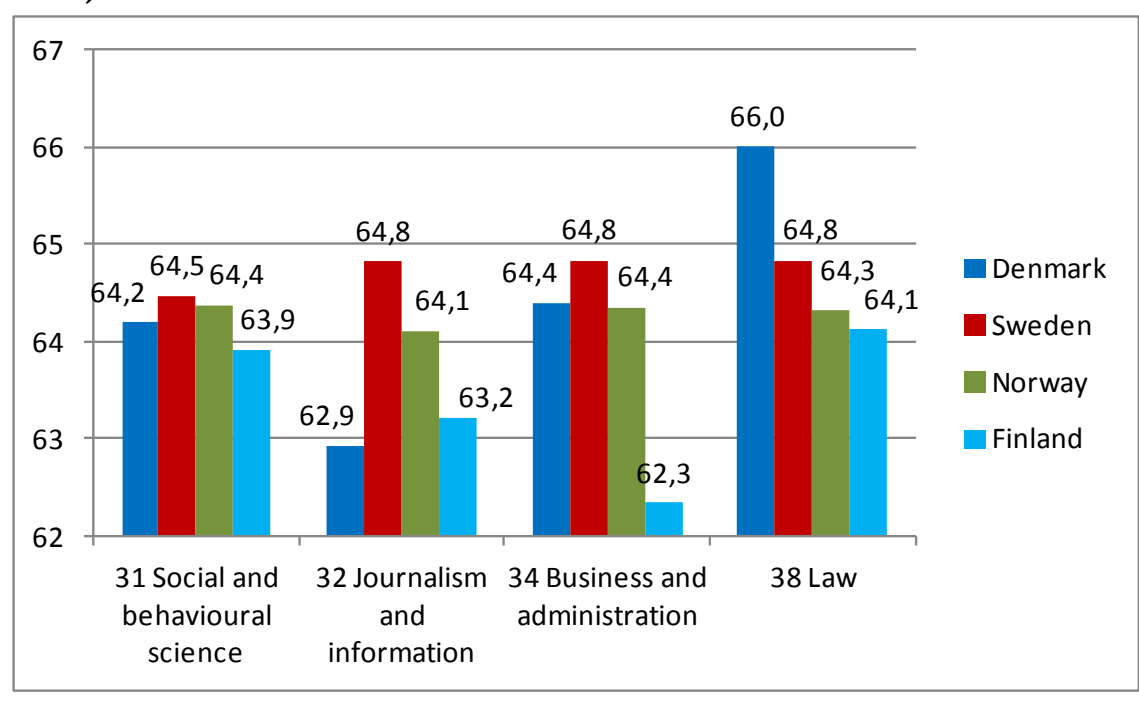

${ }^{1}$ Denmark is based on levels $5 \mathrm{~A} / 6$.

Source: Statistics Denmark, Sweden, Norway and Finland.

In Sweden, Denmark and Norway, employed persons within these fields are younger than average, with a median age of 39 to 41 years in 2009, compared to 42 years among employed ISCED level 4-6-educated persons overall in those countries. In Finland, these fields had about the same median age as all employed persons at this level of education, with one exception: The field Law in Finland had a median age among employed of 46 years in 2009, which is six to seven years higher than in all other countries. Denmark's employed, ISCED level 4-6, field 32- 
educated population were also relatively old, with a median age of 46 compared to 34 to 41 in other countries.

Overall in countries, persons with fields of education 31-38 made up one in five retirements in 2009 among ISCED level 4-6-educated persons who were employed the previous year. However this percentage varies considerably between countries, from 11 percent in Denmark to 30 percent in Finland, including 23 percent of all retirements at this level in Finland.

On average in countries, the mean age at retirement in 2009 among ISCED level 4-6-educated persons with the fields Social sciences, business and law who were employed the previous year was 64.0 years. Within Law it was higher, at 64.8 years, and especially so in Denmark, at 66.0 years. Within Business administration in Finland (a much larger group there than in other countries), mean retirement age was 62.3 years, two years lower than in other countries.

\section{ISCED Level 4-6, field 4: Science, Mathematics and Computing}

Field of education 4, Science, Mathematics and Computing, includes the four narrow fields Life science (42), Physical science (44), Mathematics and statistics (46) and Computing (48). In Nordic countries in 2008, the 230,000 persons who had completed such programmes and were employed comprised four percent of all employed, ISCED level 4-6educated 50-74 year-olds.

Figure 23. Mean age at retirement in 2009, ISCED level 4-61, field 4: Science, mathematics and computing

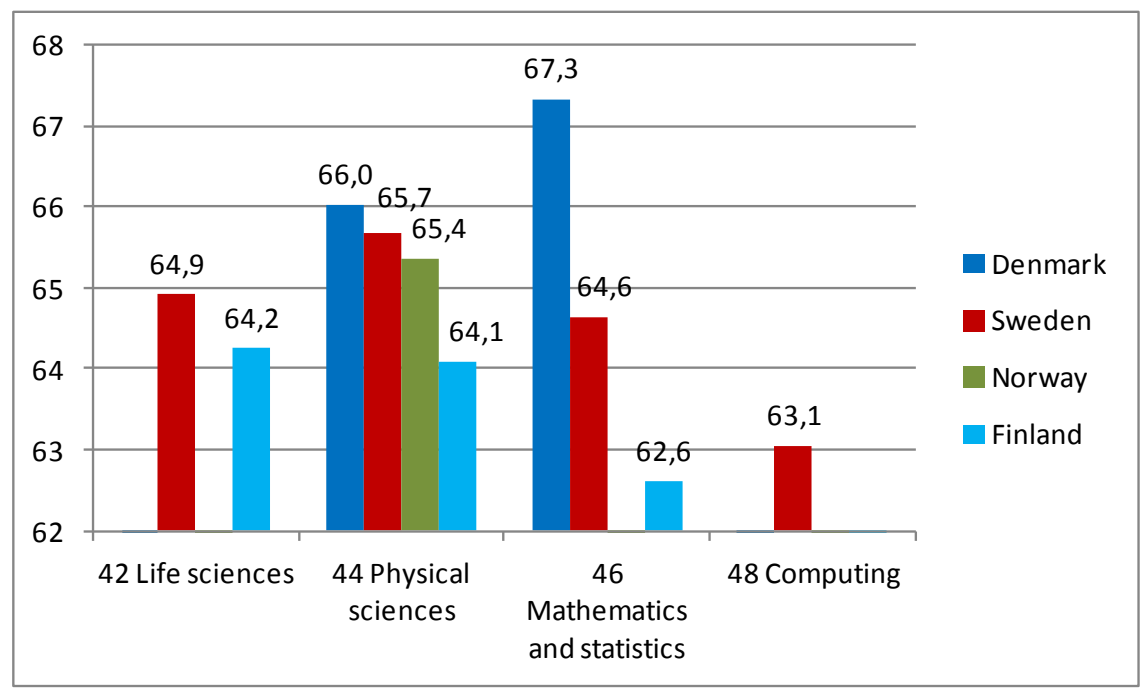

${ }^{1}$ Denmark is based on levels $5 \mathrm{~A} / 6$.

Source: Statistics Denmark, Sweden, Norway and Finland. 
The fields Life science and Computing are young groups, with a median age of 36 years and 37 years, respectively, compared to 42 years for employed ISCED level 4-6-educated persons in 2008 overall. The field Physical science is older than average, at 42 years, especially in Finland where they average 49 years.

In Nordic countries in 2009, persons with fields of education 42-48 made up 3.4 percent of retirements among ISCED level 4-6-educated persons who were employed the previous year. On average in the four countries this retiring group was 64.7 years old. Overall for broad field 4 , Denmark had the highest retirement age, at 66.4 years, and Finland the lowest, at 63.1 years.

\section{ISCED Level 4-6, field 5: Engineering, Manufacturing and Construction}

Field of education 5, Engineering, Manufacturing and Construction includes the narrow fields Engineering and engineering trades (52), Manufacturing and processing (54) and Architecture and building (58). In Nordic countries, persons who have completed such programmes comprised between 13 and 24 percent of the employed, ISCED level 4-6educated population age 50-74 in 2008. Engineering and engineering trades is the largest of the three narrow fields, making up three of four employed persons within field 5 in 2009 in Sweden, Norway and Finland, and half in Denmark .

Figure 24. Mean age at retirement in 2009, ISCED level 4-61, field 5: Engineering, manufacturing and construction

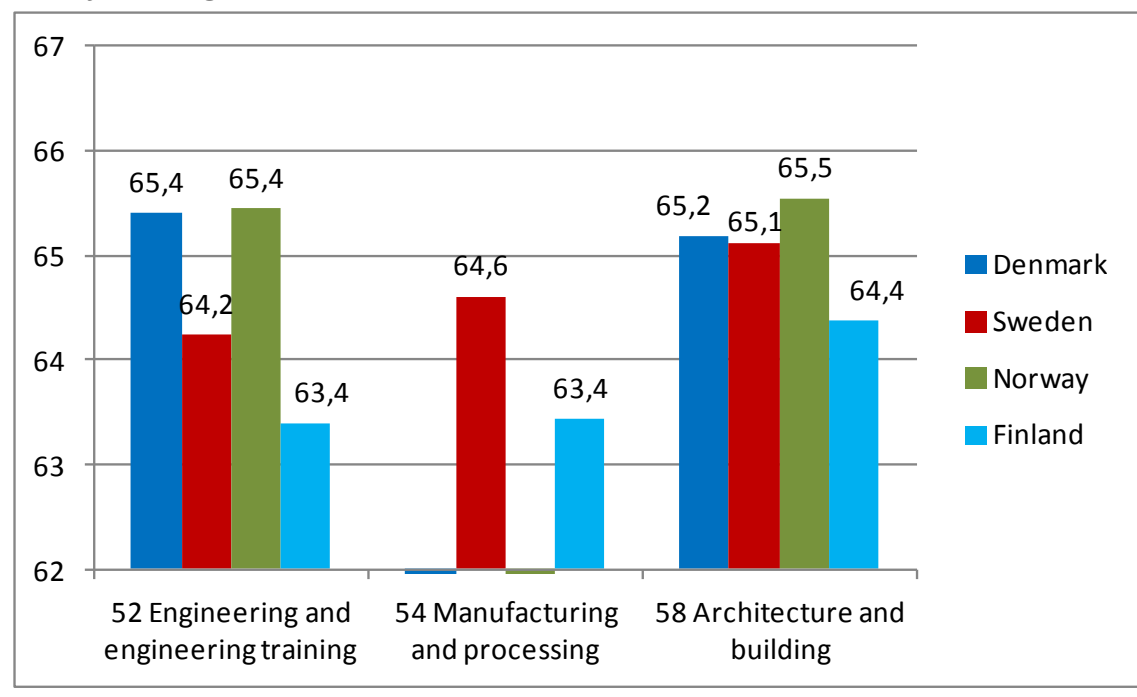

${ }^{1}$ Denmark is based on levels $5 \mathrm{~A} / 6$.

Source: Statistics Denmark, Sweden, Norway and Finland. 
In 2009, employed persons in Nordic countries within the broad field Engineering, manufacturing and construction had a median age of 42 , in line with the average for persons age 50-74 with an ISCED 4-6 level education. In Finland and Norway, persons within the narrow field Architecture and building were older than average, at 48 years and 45 years, respectively.

Overall in Nordic countries, persons with fields of education 52-58 made up 15 percent of all retirements in 2009 among ISCED level 4-6educated 50-74 year-olds who were employed the previous year, ranging from 10 percent in Sweden to 24 percent in Finland. The narrow field Engineering and engineering trades accounted for the most of these retirements in all countries,

In Nordic countries, the mean age at retirement in 2009 among ISCED level 4-6-educated persons with the field Engineering, manufacturing and construction who were age 50-74 and employed the previous year was 64.6 years, slightly higher than the mean retirement age of 64.0 years among ISCED level 4-6 educated persons overall. Mean retirement age among persons in field 5 was highest in Norway and Denmark, at 65.4 years and 65.3 years, respectively.

\section{ISCED Level 4-6, field 6: Agriculture and Veterinary}

Field of education 6, Agriculture and Veterinary, includes the two narrow fields Agriculture, forestry and fishery (62) and Veterinary (64). These are small groups in Nordic countries, comprising together between one and three percent employed, ISCED level 4-6-educated persons age 50-74 in 2008. The narrow field Agriculture, forestry and fishery makes more than seven of ten persons in this group in all countries.

In 2009, the median age of employed persons within Agriculture, forestry and fishery was 44 years, and within Veterinary it was 42 years, similar to the median age of 42 among all employed at the ISCED 4-6 level. In Norway, however, both narrow fields were younger than average, with a median age of 40 years. In Finland the narrow field Agriculture, forestry and fishery was older than average, at 45 years. 
Figure 25. Mean age at retirement in 2009, ISCED level 4-61, field 6: Agriculture and Veterinary

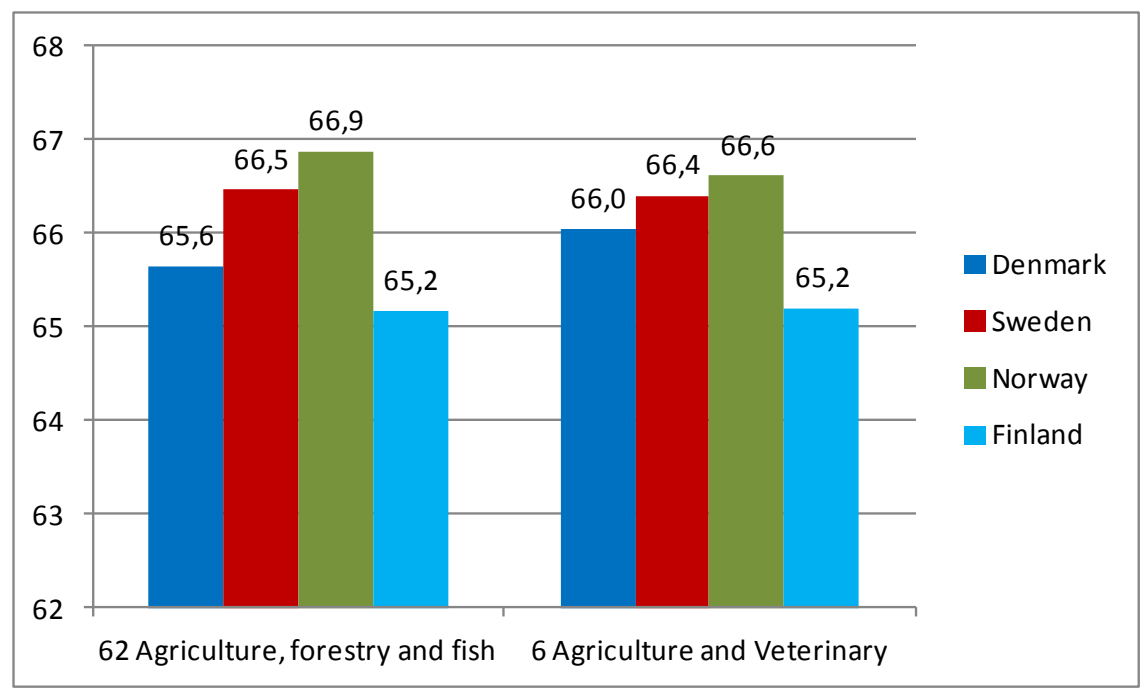

${ }^{1}$ Denmark is based on levels $5 \mathrm{~A} / 6$.

Source: Statistics Denmark, Sweden, Norway and Finland.

In 2009, persons with fields of education 62 and 64 made up four percent of retirements among ISCED level 4-6-educated 50-74 year-olds who were employed the previous year in Finland, and less than one percent in other countries.

In Nordic countries, the mean age at retirement in 2009 among ISCED level 4-6-educated persons with the field Agriculture and Veterinary who were age 50-74 and employed the previous year was 66.1 years. The retirement age for this field was higher than 65 in all four countries, and highest in Norway at 66.6 years.

\section{ISCED Level 4-6, field 7: Health and Welfare}

Field of education 7, Health and Welfare, includes the two narrow fields Health (72) and Social Services (76). In Nordic countries this is a large group, comprising 17 to 24 percent of ISCED level 4-6-educated 50-74 year-olds in Sweden, Finland and Norway, and 39 percent in Denmark. The narrow field Health makes up most of the Health and Welfare group in Sweden, Finland and Norway. Denmark has a large number of persons with the field Social Services, at 19 percent of employed 50-74 year-olds at this educational level, whereas in other countries this group is much smaller, at four percent or less. 
Figure 26. Mean age at retirement in 2009, ISCED level 4-61, field 7: Health and Welfare

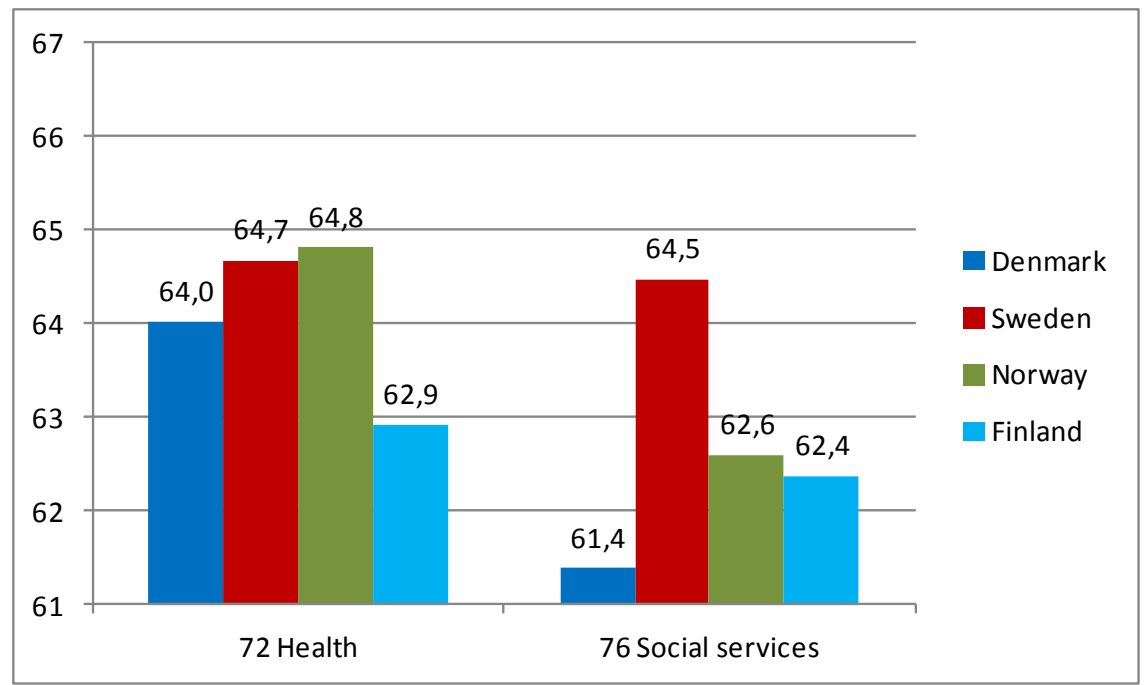

${ }^{1}$ Denmark is based on levels $5 \mathrm{~A} / 6$.

Source: Statistics Denmark, Sweden, Norway and Finland.

In Sweden and Denmark employed persons within this field of education are older than average, with a median age of 45 compared to 41-42 years for ISCED level 4-6 educated overall in those countries. In Finland and Norway the Health and Welfare group had the same median age in 2009 as employed ISCED level 4-6-educated persons overall.

Overall in Nordic countries, persons with fields of education 72 and 76 made up 22 percent of retirements in 2009 among ISCED level 4-6educated 50-74 year-olds who were employed the previous year. This percentage varied considerably between countries, from 15 percent in Finland to 37 percent in Denmark.

On average in countries, the mean age at retirement in 2009 among ISCED level 4-6-educated persons with the field Health who were employed the previous year was 64.1 years. Mean retirement age was highest in Norway and Sweden at 64.8 years and 64.7 years, respectively, lower in Denmark, at 64.0 years and lowest in Finland, at 62.9 years.

Among persons with field Social Services the mean retirement age was lower, at 62.7 years. Most of these retirements were in Sweden and Denmark, which had very different mean retirement ages in this field of 64.5 years and 61.4 years, respectively. 


\section{ISCED Level 4-6, field 8: Services}

Field of education 8, Services, includes the four narrow fields Personal services (81), Transport services (84), Environmental protection (85) and Security services (86). In Sweden, Finland and Norway, Services comprised between three and four percent of all employed, ISCED level 4-6educated persons in 2008. In Denmark this group is smaller, at one percent of employed in 2008.

This is a relatively young group, especially persons within the field Personal services, who have a median age of 37 years or lower in all countries, compared to 42 years for employed ISCED 4-6-educated overall. The field Transport services, however, has a higher than average median age in all countries.

\section{Figure 27. Mean age at retirement in 2009, ISCED level 4-61 field 8: Services}

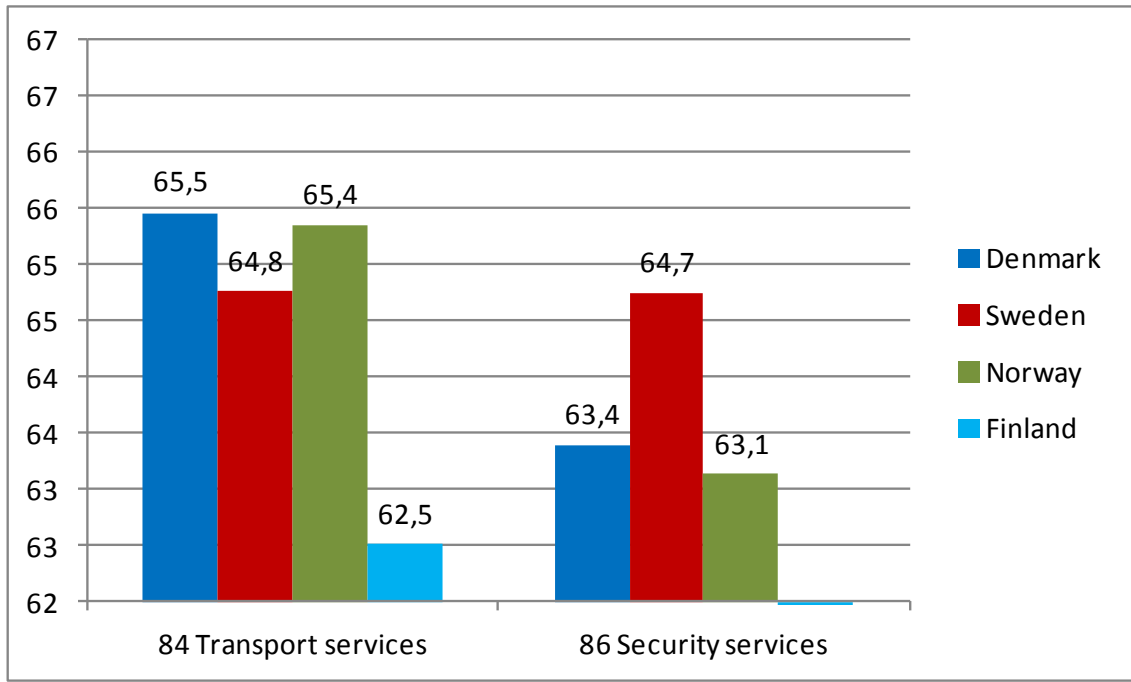

${ }^{1}$ Denmark is based on levels $5 \mathrm{~A} / 6$.

Source: Statistics Denmark, Sweden, Norway and Finland.

On average in countries, persons with fields of education 81-86 made up 4.4 percent of retirements in 2009 among ISCED level 4-6-educated 5074 year-olds who were employed the previous year. In Denmark, this field made up a smaller portion of retirees, at 1.3 percent.

On average in the four countries, the mean age at retirement in 2009 among ISCED level 4-6-educated 50-74 year-olds with the field Services who were employed the previous year was 63.6 years. Within Transport Services, the mean retirement age was 64.5 years, and within Security services, 63.0 years. Compared to Denmark and Finland, Sweden and Norway had high retirement ages within the field Services, at 64.7 years 
and 64.3 years, respectively. Finland had a particularly low retirement age for this field, at 61.3 years.

\subsection{Projections}

In Nordic countries, the majority of persons who were age 50-74 and employed in 2008 will retire before 2020 . The projections show how the proportion of retired persons among groups of persons who were employed in 2008 will grow over this period.

In countries on average, the higher the level of education, the lower the percentage of projected retirements 2020. This pattern corresponds to the differences in mean retirement age observed in the different levels of education. Among employed 50-74 year-olds in 2008 with ISCED level of education 1 or 2 (primary), 77 percent are projected to retire by the year 2020, whereas among persons with tertiary education, 61 percent are projected to retire.

It should be noted that a high average age at retirement in 2009 does not necessarily mean that a low number of retirements is to be expected in coming years. Conversely, a low average retirement age does not necessarily lead to a greater-than-average number of retirements. Average retirement age is based on persons who retired in 2009, whereas the projections are based on persons who have not yet retired. The age distributions of these two groups are not necessarily the same, and the distributions vary between countries and levels and fields of education. 
Figure 28. Projected retirements in Nordic countries between 2009-2020 by ISCED level of education. Cumulative percent of persons who were 50-74 years old and employed in 2008

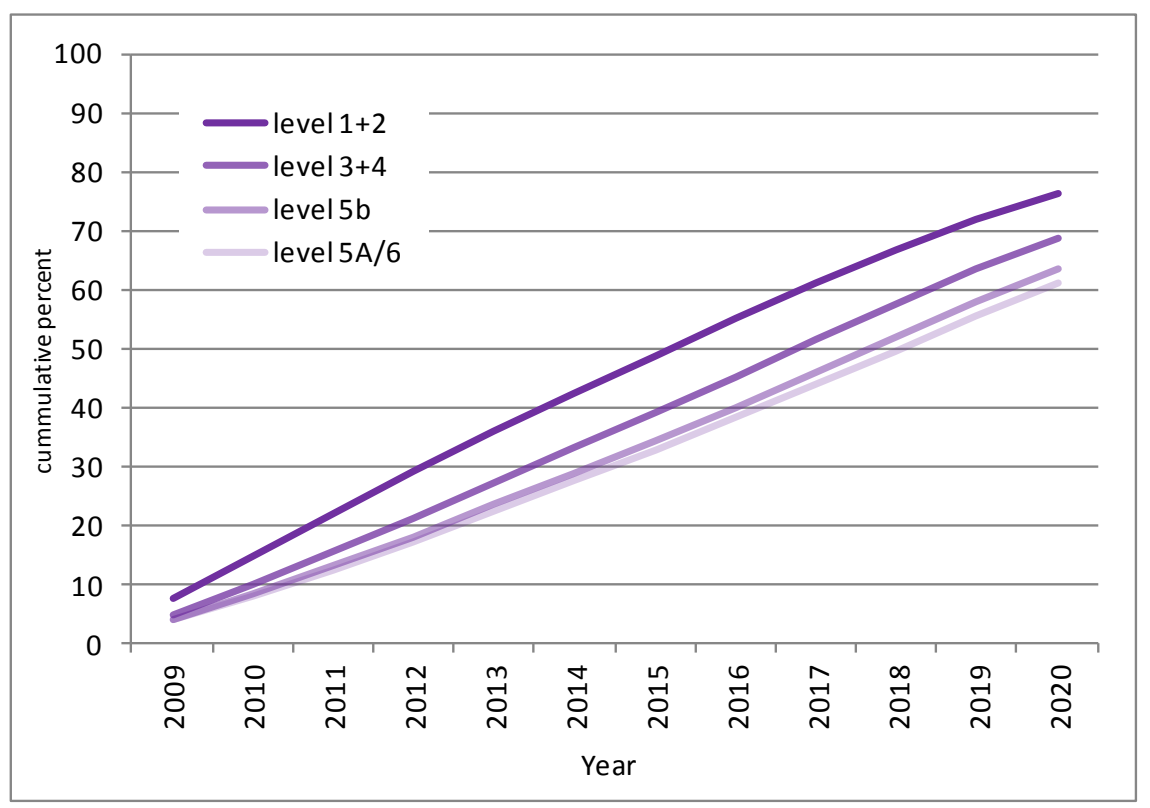

Graph shows the unweighted mean of the projections in each country. Source: Statistics Sweden.

In Finland, Denmark and Sweden, roughly eight of ten employed persons in 2008 whose highest level of education was at the primary level are projected to retire by 2020 . In Norway projected retirements are somewhat lower in this group, at seven of ten. Among persons with a secondary-level education, projected retirements are lower than those among primary-educated, at roughly seven of ten employed in 2008, and six of ten in Norway. 
Figure 29. Projected retirements in Nordic countries between 2009-2020 by ISCED levels of education $1+2$ and $3+4$. Cumulative percent of persons who were age 50-74 and employed in 2008

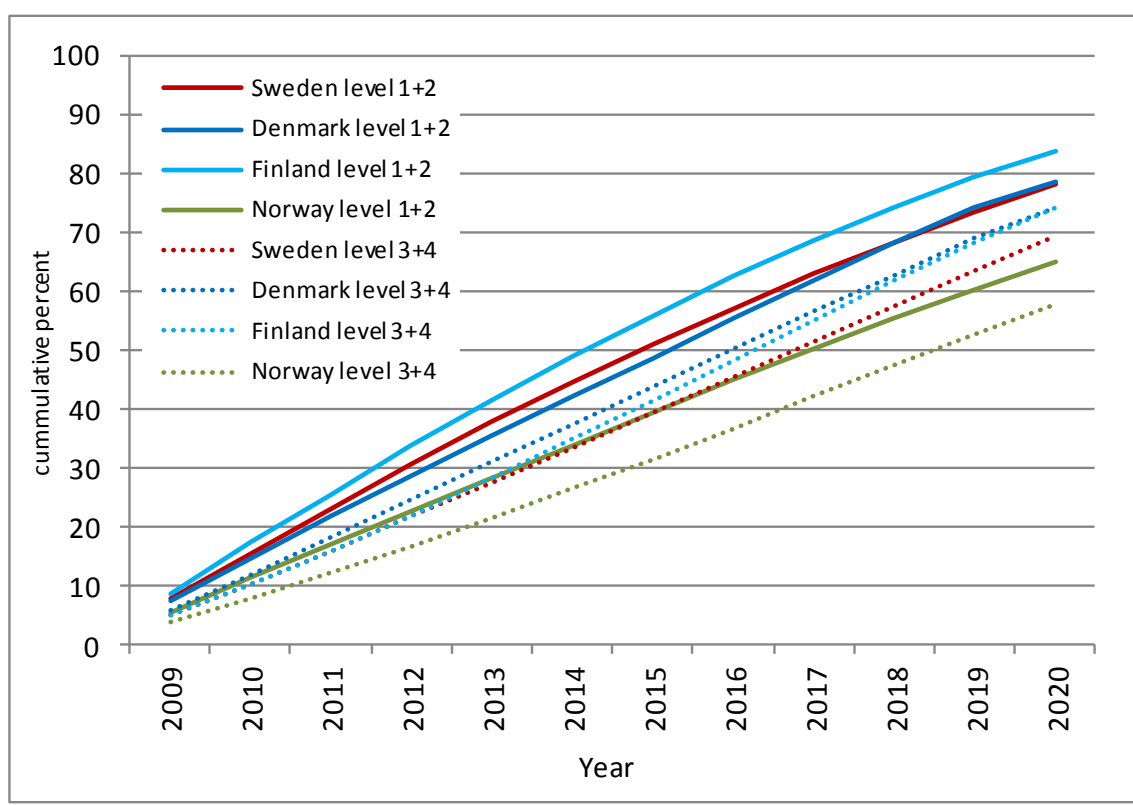

Source: Statistics Sweden.

Projected retirements are lower among tertiary-educated persons than they are among persons with lower levels of education. In Finland, Denmark and Sweden between 60-70 percent of persons with and ISCED level 5 or 6 level education who were age 50-74 and employed in 2008 are projected to retire by the year 2020, compared to 80 percent of those whose highest level of education is at the primary level. In Norway, roughly half of tertiary-educated are projected to retire. 
Figure 30. Projected retirements in Nordic countries between 2009-2020 by ISCED levels of education $5 \mathrm{~b}$ and $5 A / 6$. Cumulative percent of persons who were 50-74 years old and employed in 2008

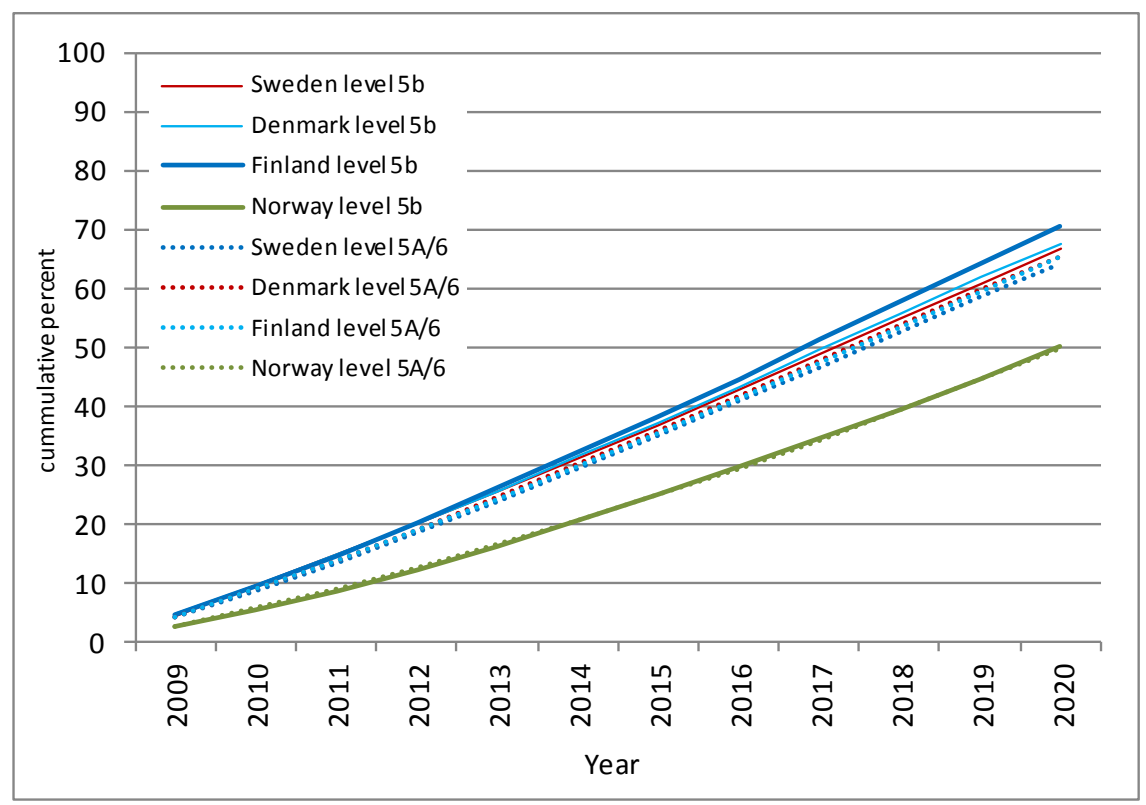

Source: Statistics Sweden.

Nordic countries have variable retirement ages, often allowing people to receive pension income at age 60 or even earlier. Additionally, early retirement schemes have been a common avenue for persons to leave the labour market. The regulations covering early retirement have undergone changes in all countries in recent years, and in the long run the reforms are expected to decrease early retirement. In general, however, reforms have transition rules which exempt older workers; It is unclear how much the phenomenon of early retirement will be reduced over the next ten years. The projections of early retirements presented here are based on employed 50 year-olds in 2008, many of whom will be exempted from changes in early retirement schemes.

In 2009, early retirement was relatively common among persons whose highest level of education was at the primary level. In Denmark, just under half of all primary-educated persons who were age 50 in 2008 are projected to retire by 2020. In Finland and Norway projected retirements are lower among 50 year-olds in this educational group, at roughly one in three by the year 2020. In Sweden one in five is expected to retire.

For persons with a secondary-level education, early retirement is less common. In Denmark, a third of 50 year-olds who were employed in 2008 are projected to retire by 2020 . In other countries early retirement 
is expected to be lower, at about 15 percent or less of 50-year olds who were employed in 2008 and whose highest level of education was at the secondary level.

Figure 31. Projected retirements in Nordic countries between 2009-2020 by ISCED levels of education $1+2$ and $3+4$. Cumulative percent of persons who were age 50 and employed in 2008

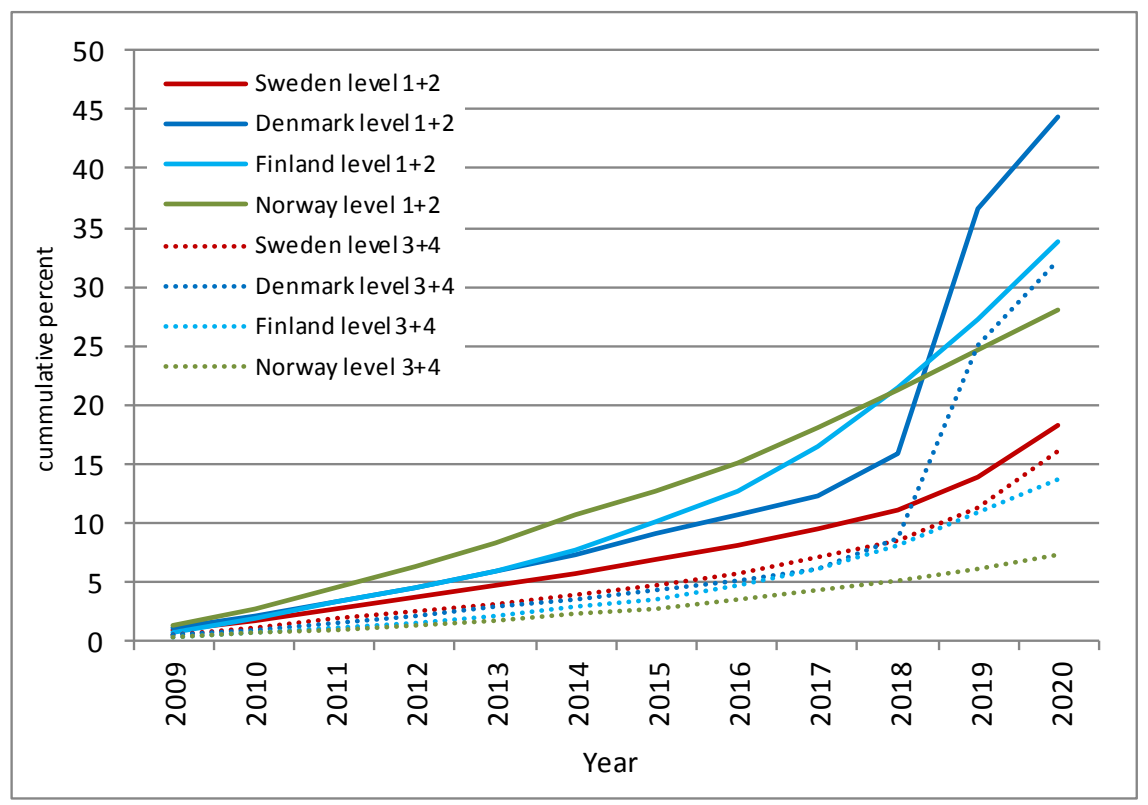

Source: Statistics Sweden.

Among the tertiary-educated, early retirement is less common than it is among persons with lower levels of education. Based on retirements observed in 2009, fewer than ten percent of tertiary-educated persons who were age 50 and employed in 2008 are projected to retire by the year 2020. In Norway, projected early retirements among tertiary educated are slightly higher than in other countries, at 7-9 percent of persons age 50 in 2008. In Sweden and Denmark they are lower, at two percent or less of persons age 50 in 2008. 
Figure 32. Projected retirements in Nordic countries between 2009-2020 by ISCED levels of education $5 B$ and 5A/6. Cumulative percent of persons who were age 50 and employed in 2008

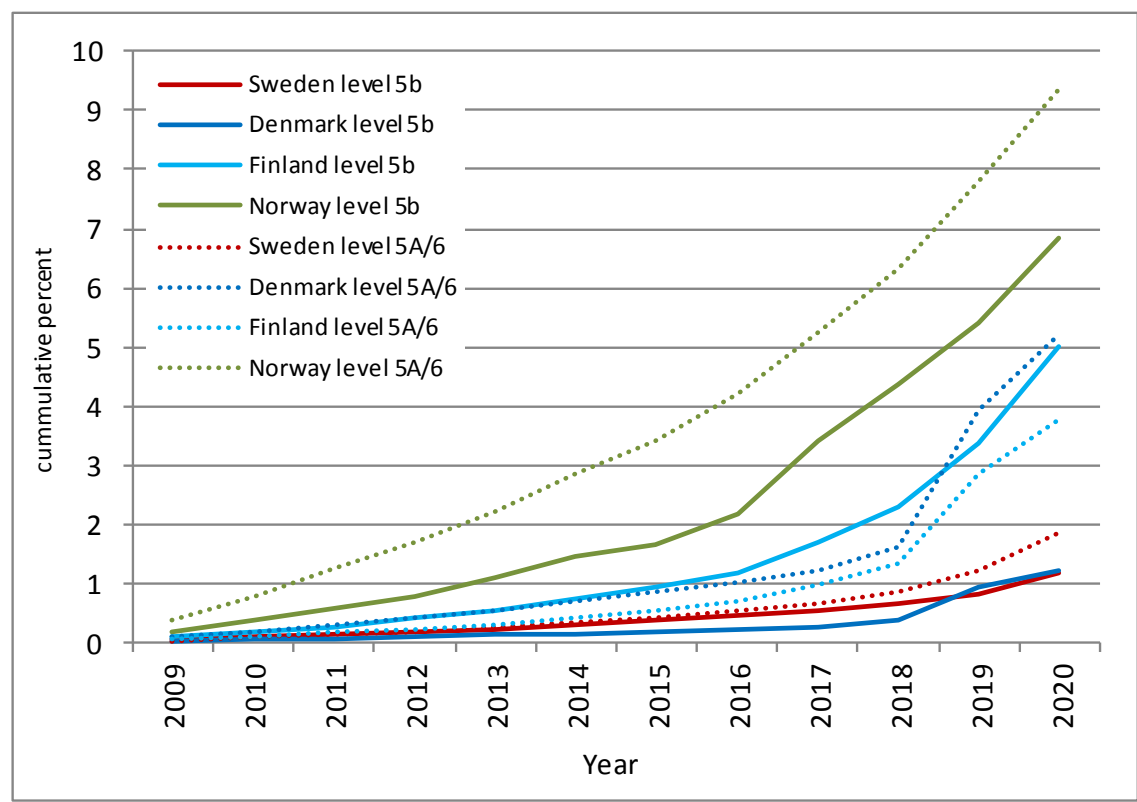

Source: Statistics Sweden.

\subsection{Concluding discussion}

It is clear from this analysis that average retirement age varies depending on educational level and field of study. The study confirms what other studies have found - that highly educated often retire at an older age than persons with lower levels of education. It adds to these conclusions information on how retirement age varies for specific levels and fields of education.

Still, education is just one of many important factors that determine when a person choses to retire. Other important factors include the type of job one has, the pension regimes in which one participates, and even culture. Accordingly, this report should be considered a complement to studies that focus on other factors that affect retirement age. 
The primary conclusions of this report are as follows:

- The labour labour force will change considerably over the next few years. Absent additional pension policy changes, roughly 60 percent of working persons with post-secondary education age 50+ will retire by 2020. Among persons with a low level of education roughly 75 percent will retire.

- Average age at retirement varies considerably between countries and across fields of study. For all areas of study combined, Denmark and Finland have a notably lower average age at retireement than Sweden or Norway, roughly a year and a half lower for men and two years lower for women. Exactly why retirement ages vary in this way is a complex issue. It is affected not only by educational attainment or gender, but also by pension policies in each country and other incentives individuals face given their specific employment situation.

- Regardless of area of study, men generally retired at an older age than women in 2010. This was true in all four countries, and is a pattern consistent with what has been observed in earlier studies.

- Persons with a post-secondary education tend to retire older than persons with a secondary education. However, persons with only primary education do not retire especially young, according to the model.

- Average age at retirement varies across the broad areas of study, both at the secondary and tertiary levels. Persons whose education is in health and welfare tend to retire younger than others.

- It is difficult to explain exactly why it varies or whether observed differences will hold in the future.

- The projections show that the majority of persons age 50+ and employed in 2008 will retire before the year 2020. Retirements are expected to be somewhat lower overall in Norway than in other countries.

It is clear that persons with a high level of education tend to retire older than others. Over the past few decades with the expansion of higher education, average educational attainment has risen a great deal. This is a trend that is continuing today as more and more people chose to study at the post-secondary level. If this trend continues, and it probably will for some time, there are a few policy-related implications.

The main one is that average age at retirement will probably rise even if no changes are made in pension policy. If in the future there are more people with high levels of education and such people retire older 
than others, then in the future more people will retire at a higher age than they do today. Second, a larger portion of persons with low levels of education will retire than persons with a higher level of education in the near future. This is true simply because persons with low levels of education tend to be older than others and are thus closer to retirement today than others.

There appears to be more "room" in Denmark and Finland than in Sweden or Norway to realise increases in average retirement age in the age cohort where such increases are most likely, age 62-67+. This is because retirement age is today relatively low in those countries. There is also more "room" to close the gender gap in average retirement age in Denmark than in other countries, simply because this gap is relatively large there.

Of course, the decision to retire is affected by many factors, not simply educational background. The educational groups used in this analysis, like any groupings, are necessarily broad and include persons working in a wide range of professions and in different industries. There are pension agreements that are specific to individual industries and also employer-specific arrangements. A natural complement to this report would be an analysis based on occupation, or one based on both occupation and industry.

Regarding the model used here, it should be emphasised that like any model, it simplifies what is in reality a complex situation affected by many factors. For example, the model does not differentiate people depending on the amounts of their income or the pension amount available to them if and when they retire.

\section{Projections, pension reform and long-term policy issues}

The projections show that a large portion of today's working 50-74-year olds will have retired by the year 2020. Since most of these persons are fully or partially exempt from recent pension reforms, it is not expected that the reforms will significantly impact on retirement age in the shortterm. With this in mind, it is worth saying a few words about what countries might expect in the longer term.

Recent reforms of pension systems have had as a primary goal reducing future pension costs. The impacts of rising life expectancy and a rising number of retired persons have made it clear that the pre-reform pension systems were financially unsustainable.

Reforms in all countries have a few things in common. Eligibility ages are scheduled to rise and forecasted pension amounts have been linked to life expectancy. Pensions are expected to be lower. In theory, pensions 
will also become less available to persons of working age. Opportunities for early retirement are being phased out.

Although the goal of these reforms is to ensure the future financial stability of the pension systems, it is unclear what the effects will be. Because of transition rules, persons nearing retirement today are often partially or completely exempt from the reforms. This means that the forecasted cost savings are only forecasts; whether they will materialise remains to be seen. The effects the reforms will have on individual's decision about when to retire are as yet unknown.

There is some evidence that people are working longer than they used to. Participation in the labour force among 65-70-year-olds has risen in Sweden in recent years. If this trend continues and happens in other countries, then one of the goals of pension reform will have been realised.

However, there may be unintended consequences as well. For example, if older people work longer, will there be fewer jobs available for young people? If so, will unemployment among young people rise? Also, will more and more elderly be classified as disabled or unemployed? It is likely that the cost savings forecasted by the pension reforms will be accompanied by cost increases in other areas of the social welfare system. Whether the decreases in costs will be larger than the increases remains to be seen.

In the medium and long term, the forecasted amounts of pensions are also an issue. In addition to being payed out later, pension amounts are forecasted to be lower than they are today. An important question is then, how low can they be before the incentive to work is weakened so much that participation in the labor force drops?

People work for many reasons, one of which is the promise of a meaningful income later in life. Accordingly, occupational pension systems have often been structured to encourage long periods of service. Employees were generally given a promise of a substantial lifetime income on the condition that they worked up until a specific retirement age. Pension were often based on final earnings, so there was an incentive to work and increase earnings during the last few years of a career.

With pension reform, the "final earnings" basis for pensions is largely being replaced by a "accumulated lifetime earnings" criteria. In addition, pension "promises" are largely being replaced with pension accounts over which the retiree has full or partial control. Compared to today, the amount of pension will depend more on past earnings and less on earnings during the years immediately preceding retirement. Accordingly, working those final few years will have a much smaller effect on total expected pension pay-out than it did before. By itself, this change will 
tend to make people retire earlier than they do today, not later. Whether this effect can be counteracted by other reforms such as a flexible retirement age remain to be seen.

The existence of a "basic" pension may also be problematic. All Nordic countries provide a minimum pension to prevent poverty in old age. In general, the amount of this pension is linked to some cost of living index, the rational being that people need a minimum income to avoid poverty. Because pension reforms will significantly reduce the amount of incomebased pensions, more and more working people will see forecasted pensions that are at or very near this minimum level. For these people, the link between income, length of working life and pension amount will become weak. For them, it will become less clear that working longer or earning more will lead to a meaningfully higher pension. On the margin at least, this will tend to make people want to retire earlier rather than later.

Accordingly, decisions people make about when to stop working may be very different than those made today. If incentives to work are reduced too much, countries may witness a gradual decline in labour force participation, declining tax revenues, and possibly pension system insolvency once again. As mentioned, there may also be increase in social welfare costs due to increased poverty and unemployment. In ten or twenty years, redistributive programs such a welfare, unemployment compensation, sick pay and permanent disability may be in need of "reform" just as pension systems have been in recent years.

\subsection{Strengths and limitations of the analysis}

\section{Education registers}

The Education registers in the Nordic countries include information of the educational background of 98 percent of all residents. The education registers contain smaller percentages of persons whose level and field of education are "unknown". The percentage of population with "unknown" level of education is 0.6 percent in Sweden, 2.4 percent in Denmark, and 2.2 percent in Norway. In Finland, the total for all levels of education is shown as the sum of all those with known levels of education. The percentage with "unknown" field of education is generally larger than it is for level of education.

In this analysis, only persons with known level and field of education are included in relevant breakdowns by level and field. Because persons with "unknown" field or level are not included, any systematic difference between the age distribution of this group and the age distribution of 
those included would bias the results. However, since the "unknown" group is small any such bias is expected to be small.

In this analysis, a person's level and field of education are drawn from the 2008 registers, whereas their status as "employed in 2009" or "retired in 2009" is drawn from the 2009 register. Since the registers are updated yearly, there are small differences in the distribution of level and field of education between 2008 and 2009. Some persons classified within each level or field in 2008 are classified differently the following year because they pursued additional education, completed an education programme in 2009 , or in some cases, were re-classified for technical reasons by the statistical office.

The changes in educational registers are small compared to the overall stock of employed persons, especially in the age group 50-74. The effects such changes might have on this analysis were not investigated, but are expected to be small.

\section{ISCED 1997}

The ISCED classification system has been harmonised across European countries. However, educational systems of countries differ, as do the methods each country uses to apply the ISCED system to classify persons by educational programs. For example, the boundaries between ISCED levels 3 and 4, and ISCED levels 4 and $5 \mathrm{~b}$ are sometimes difficult to apply. A program in one country may be classified as ISCED level 4 , and a similar program in another country as ISCED level 5B. Limitations of the ISCED system should always be kept in mind when making crosscountry comparisons.

\section{Average retirement age}

The model used to calculate age at retirement was chosen with a focus on observable differences between level and field of education, as well as differences between countries. The method was applied the same way in all countries using data from the same years (2008, 2009 and 2010), and thus produces comparable results.

The base population is persons with employment income in 2008 who were registered residents in 2008 and 2009. The population excludes persons who dies or emigrated in 2009, among them persons who may have retired and emigrated in the same year. Thus the base population excludes a portion of persons who would be considered to have retired in 2009.

Average age at retirement was calculated by defining a sharp boundary between "employed in 2009" and "retired in 2009" based on whether or not a person had income from employment and/or from pension 
sources in the years 2008, 2009 and 2010. This clear definition of "retirement" makes the results comparable between countries and levels and fields of education. It is also a model that could potentially be applied in countries that lack detailed individual-based registers.

The model does not, however, capture all complexities of the transition from work to retirement. Retirement is often a period of several years rather than a clear boundary between two. Oftentimes people work part time and collect partial pensions. Others work full time while collecting a pension from a previous employer. In the model used here, both these groups would be classified as "employed in 2009". Because the model is restrictive in classifying persons as "retired in 2009", it classifies fewer persons as retired than a model that was less restrictive would. People who collect partial pensions while working are, on average, younger than persons whose entire income is from pension sources. Accordingly, a model that includes them will calculate lower mean retirement ages than those produced by this model.

Additionally, sometimes people retire fully and collect a pension, then rejoin the labour force after several years. Persons who are classified as "retired in 2009" by the model may go on to earn employment income in 2011 or later. The model accommodates for re-entry into the labour market in 2010, but not for re-entry in 2011 or later, as this data is not yet available.

The model groups all the various types of pension income (age, disability, sickness, etc.) into one variable. A person who had income from any pension source, but no employment income may be classified as having "retired in 2009". Accordingly, the group of "retired in 2009" includes persons who stopped working for reasons other than age and end-of-career choices. Since the mean age at retirement calculations are based on 50-74 year-olds, sickness and disability pensions among younger persons do not affect the analysis. But sickness and disability pensions among 50-74 year-olds does. On average, this group is younger than persons who choose to retire due to age. Accordingly, a model that excluded them would calculate lower mean retirement ages than those produced by this model.

\section{Data from 2008-2010}

The analysis uses data from three years (2008-2010), and the projections are based on retirements that occurred between 2008 and 2009. An advantage to using only the latest available data is that effects of recent changes in pension programs are most likely to show in the most recent data. Additionally, the data on educational background is recent, and individuals that comprise the data sets in each year are the same. 
A weakness is that the years 2008-2010 represent a specific period in the economy, as well as a particular period of incentives for persons facing the choice of when to retire. Such incentives are changing in Nordic countries update their pension systems with new minimum retirement ages, limitations on early retirement, and reduction in the size of pensions. The future effects of such changes cannot yet been seen in current data, so calculations of retirement age and stock projections based on current data may not hold in the future. 


\section{References}

OECD (2011): «Pensions at a Glance 2011: Retirement-Income Systems in OECD Countries, Online Country Profiles, including personal tax and social security contributions. » http://www.oecd.org/norway/47272991.pdf

Finnish Centre for Pensions (2008): «Expected effective retirement age in the Nordic countries.», Finnish Centre for Pensions Statistical Report 2/2008.

StatensPensionskasse (2011): «The Pension System», publication describing the new Norwegian pension system» https://www.spk.no/Global/Arsberetninger/

\%C3\%A5rsberetning\%202011/SPK\%20in\%20brief_the\%20pension\%20system.pdf OECD (2011): «Pensions at a Glance 2011: Retirement-income Systems in OECD and G20 Countries, » OECD Publishing http://dx.doi.org/10.1787/pension_glance2011-69-en 



\section{Appendix 1 - Data tables}

Table A1. Employed men 20081, employed men age 50-74 2008, retired in 20092 among employed men age 50-74 in 2008, mean and median retirement age by ISCED 1997 level of education

\begin{tabular}{|c|c|c|c|c|c|c|c|}
\hline \multirow[t]{2}{*}{ MEN } & & \multicolumn{6}{|c|}{ ISCED 1997 level of education } \\
\hline & & $1+2$ & $3^{4}$ & 4 & $5 b$ & $5 A / 6$ & all levels ${ }^{2}$ \\
\hline \multirow[t]{5}{*}{ Sweden } & employed 2008 & 475,656 & $1,230,964$ & 187,749 & 155,428 & 449,329 & $2,520,336$ \\
\hline & employed 2008 , age $50-74$ & 188,034 & 345,137 & 51,916 & 50,498 & 146,577 & 784,232 \\
\hline & retired in 2009 , age $50-74$ & 13,104 & 17,069 & 1,453 & 2,635 & 6,000 & 40,368 \\
\hline & mean age at retirement & 65.0 & 64.4 & 64.1 & 65.2 & 65.3 & 64.8 \\
\hline & median age at retirement & 63 & 63 & 62 & 63 & 63 & 63 \\
\hline \multirow[t]{5}{*}{ Denmark } & employed 2008 & 407,651 & 682,131 & .. & 89,938 & 288,727 & $1,510,589$ \\
\hline & employed 2008 , age $50-74$ & 98,469 & 211,267 & .. & 27,149 & 103,757 & 448,183 \\
\hline & retired in 2009 , age $50-74$ & 6,974 & 11,867 & .. & 1,249 & 4,381 & 24,942 \\
\hline & mean age at retirement & 63.2 & 63.1 & .. & 63.4 & 64.5 & 63.4 \\
\hline & median age at retirement & 61 & 61 & .. & 61 & 63 & 61 \\
\hline \multirow[t]{5}{*}{ Finland } & employed 2008 & 324,877 & 647,185 & 7,916 & 134,106 & 273,202 & $1,387,286$ \\
\hline & employed 2008 , age $50-74$ & 109,791 & 151,889 & 1,805 & 59,237 & 84,135 & 406,857 \\
\hline & retired in 2009 , age $50-74$ & 10,206 & 8,051 & 27 & 3,079 & 3,683 & 25,046 \\
\hline & mean age at retirement & 63.9 & 61.7 & 61.2 & 63.3 & 64.2 & 63.1 \\
\hline & median age at retirement & 61 & 60 & 60 & 61 & 62 & 61 \\
\hline \multirow[t]{5}{*}{ Norway } & employed 2008 & 337,446 & 580,479 & 53,872 & 36,863 & 355,120 & $1,401,281$ \\
\hline & employed 2008 , age $50-74$ & 69,942 & 191,404 & 16,633 & 21,071 & 107,040 & 410,395 \\
\hline & retired in 2009 , age $50-74$ & 3,800 & 7,237 & 478 & 585 & 2,883 & 15,107 \\
\hline & mean age at retirement & 64.1 & 64.4 & 64.4 & 65.5 & 65.4 & 64.6 \\
\hline & median age at retirement & 63 & 63 & 63 & 64 & 64 & 63 \\
\hline
\end{tabular}

${ }^{1}$ includes persons with income from employment in 2008 who were registered residents on 31 December 2008 and 31 December 2009.

${ }^{2} \mathrm{~A}$ person is classified as having "retired in 2009" if they were registered residents in 2008 and 2009, had income from employment in 2008, had no income from employment in 2009 , had pension income in 2009, and either 1 ) had no employment income but positive pension income in 2010 or 2 ) were not a registered resident in 2010.

${ }^{3}$ includes "unknown/other" in Sweden (0.63\% of persons with employment income in 2008) and Denmark (2.4\% of persons with employment income in 2008) and Norway (2.21\% of persons with employment income in 2008). In Finland the "all levels" total is the sum of all persons with known level of education.

${ }^{4}$ Includes level 3 and 4 for Denmark. 
Table A2. Employed women $2008^{1}$, employed women age 50-74 2008, retired in $2009^{2}$ among employed women age 50-74 in 2008, mean and median retirement age by ISCED 1997 level of education

\begin{tabular}{|c|c|c|c|c|c|c|c|}
\hline \multirow[t]{2}{*}{ WOMEN } & & \multicolumn{6}{|c|}{ ISCED 1997 level of education } \\
\hline & & $1+2$ & $3^{4}$ & 4 & $5 b$ & $5 A / 6$ & all levels ${ }^{2}$ \\
\hline \multirow[t]{5}{*}{ Sweden } & employed 2008 & 351,740 & $1,102,009$ & 136,720 & 241,568 & 588,822 & $2,431,115$ \\
\hline & employed 2008 , age $50-74$ & 122,514 & 348,784 & 22,846 & 100,517 & 164,992 & 760,692 \\
\hline & retired in 2009 , age $50-74$ & 10,784 & 19,099 & 894 & 4,244 & 6,799 & 41,873 \\
\hline & mean age at retirement & 64.3 & 63.5 & 63.9 & 64.1 & 64.8 & 64.0 \\
\hline & median age at retirement & 63 & 62 & 63 & 63 & 63 & 63 \\
\hline \multirow[t]{5}{*}{ Denmark } & employed 2008 & 343,184 & 594,585 & .. & 65,187 & 401,477 & $1,432,948$ \\
\hline & employed 2008 , age $50-74$ & 101,167 & 155,124 & .. & 19,699 & 118,873 & 399,597 \\
\hline & retired in 2009 , age $50-74$ & 7,981 & 9,616 & ... & 907 & 5,213 & 24,040 \\
\hline & mean age at retirement & 62.0 & 62.1 & .. & 62.7 & 62.6 & 62.2 \\
\hline & median age at retirement & 59 & 60 & .. & 61 & 60 & 60 \\
\hline \multirow[t]{5}{*}{ Finland } & employed 2008 & 247,641 & 566,807 & 7,586 & 222,734 & 318,210 & $1,362,978$ \\
\hline & employed 2008 , age $50-74$ & 95,756 & 160,841 & 2,137 & 89,777 & 67,661 & 416,172 \\
\hline & retired in 2009 , age $50-74$ & 7,687 & 7,608 & 25 & 3,690 & 2,719 & 21,729 \\
\hline & mean age at retirement & 63.0 & 61.7 & 59.9 & 62.2 & 63.0 & 62.4 \\
\hline & median age at retirement & 61 & 60 & 60 & 61 & 61 & 61 \\
\hline \multirow[t]{5}{*}{ Norway } & employed 2008 & 295,133 & 505,243 & 25,867 & 16,978 & 449,266 & $1,315,284$ \\
\hline & employed 2008 , age $50-74$ & 72,002 & 181,493 & 8,721 & 4,039 & 110,833 & 379,380 \\
\hline & retired in 2009 , age $50-74$ & 4,177 & 7,294 & 237 & 69 & 3,028 & 14,894 \\
\hline & mean age at retirement & 63.6 & 63.8 & 63.5 & 62.1 & 64.1 & 63.8 \\
\hline & median age at retirement & 62 & 62 & 62 & 61 & 63 & 62 \\
\hline
\end{tabular}

${ }^{1}$ includes persons with income from employment in 2008 who were registered residents on 31 December 2008 and 31 December 2009.

${ }^{2}$ A person is classified as having "retired in 2009" if they were registered residents in 2008 and 2009, had income from employment in 2008, had no income from employment in 2009, had pension income in 2009, and either 1) had no employment income but positive pension income in 2010 or 2) were not a registered resident in 2010.

${ }^{3}$ includes "unknown/other" in Sweden (0.63\% of persons with employment income in 2008) and Denmark (2.4\% of persons with employment income in 2008$)$ and Norway $(2.21 \%$ of persons with employment income in 2008). In Finland the "all levels" total is the sum of all persons with known level of education.

${ }^{4}$ Includes level 3 and 4 for Denmark. 
Table A3. Employed persons $2008^{1}$, employed persons age 50-74 2008, retired in $2009^{2}$ among employed persons age 50-74 in 2008, mean and median retirement age by ISCED 1997 level of education

\begin{tabular}{|c|c|c|c|c|c|c|c|}
\hline \multicolumn{2}{|c|}{ WOMEN + MEN } & \multicolumn{6}{|c|}{ ISCED 1997 level of education } \\
\hline & & $1+2$ & $3^{4}$ & 4 & $5 b$ & $5 A / 6$ & all levels ${ }^{2}$ \\
\hline \multirow[t]{5}{*}{ Sweden } & employed 2008 & 827,396 & $2,332,973$ & 324,469 & 396,996 & $1,038,151$ & $4,951,451$ \\
\hline & employed 2008 , age $50-74$ & 310,548 & 693,921 & 74,762 & 151,015 & 311,569 & $1,544,924$ \\
\hline & retired in 2009 , age $50-74$ & 23,888 & 36,168 & 2,347 & 6,879 & 12,799 & 82,241 \\
\hline & mean age at retirement & 64.7 & 64.0 & 64.0 & 64.5 & 65.1 & 64.4 \\
\hline & median age at retirement & 63 & 63 & 62 & 63 & 63 & 63 \\
\hline \multirow[t]{5}{*}{ Denmark } & employed 2008 & 750,835 & $1,276,716$ & .. & 155,125 & 690,204 & $2,943,537$ \\
\hline & employed 2008 , age $50-74$ & 199,636 & 366,391 & .. & 46,848 & 222,630 & 847,780 \\
\hline & retired in 2009 , age $50-74$ & 14,955 & 21,483 & .. & 2,156 & 9,594 & 48,982 \\
\hline & mean age at retirement & 62.6 & 62.6 & .. & 63.1 & 63.5 & 62.8 \\
\hline & median age at retirement & 60 & 60 & .. & 61 & 61 & 60 \\
\hline \multirow[t]{5}{*}{ Finland } & employed 2008 & 572,518 & $1,213,992$ & 15,502 & 356,840 & 591,412 & $2,750,264$ \\
\hline & employed 2008 , age $50-74$ & 205,547 & 312,730 & 3,942 & 149,014 & 151,796 & 823,029 \\
\hline & retired in 2009, age 50-74 & 17,893 & 15,659 & 52 & 6,769 & 6,402 & 46,775 \\
\hline & mean age at retirement & 63.5 & 61.7 & 60.6 & 62.7 & 63.7 & 62.8 \\
\hline & median age at retirement & 61 & 60 & 60 & 61 & 62 & 61 \\
\hline \multirow[t]{5}{*}{ Norway } & employed 2008 & 632,579 & $1,085,722$ & 79,739 & 53,842 & 804,386 & $2,716,565$ \\
\hline & employed 2008 , age $50-74$ & 141,944 & 372,897 & 25,354 & 25,110 & 217,873 & 789,775 \\
\hline & retired in 2009 , age $50-74$ & 7,977 & 14,531 & 715 & 654 & 5,911 & 30,001 \\
\hline & mean age at retirement & 63.9 & 64.1 & 64.1 & 65.1 & 64.7 & 64.2 \\
\hline & median age at retirement & 63 & 62 & 62 & 63 & 63 & 63 \\
\hline
\end{tabular}

${ }^{1}$ includes persons with income from employment in 2008 who were registered residents on 31 December 2008 and 31 December 2009.

${ }^{2}$ A person is classified as having "retired in 2009" if they were registered residents in 2008 and 2009, had income from employment in 2008, had no income from employment in 2009 , had pension income in 2009, and either 1 ) had no employment income but positive pension income in 2010 or 2 ) were not a registered resident in 2010

${ }^{3}$ includes "unknown/other" in Sweden (0.63\% of persons with employment income in 2008) and Denmark (2.4\% of persons with employment income in 2008) and Norway (2.21\% of persons with employment income in 2008). In Finland the "all levels" total is the sum of all persons with known level of education.

${ }^{4}$ Includes level 3 and 4 for Denmark. 
Table A4. Employed men 2008 ${ }^{1}$, employed men age 50-74 2008, retired in $2009^{2}$ among men age 50-74 in 2008, mean and median retirement age by ISCED 1997 field of education for men with highest ISCED level 3 education

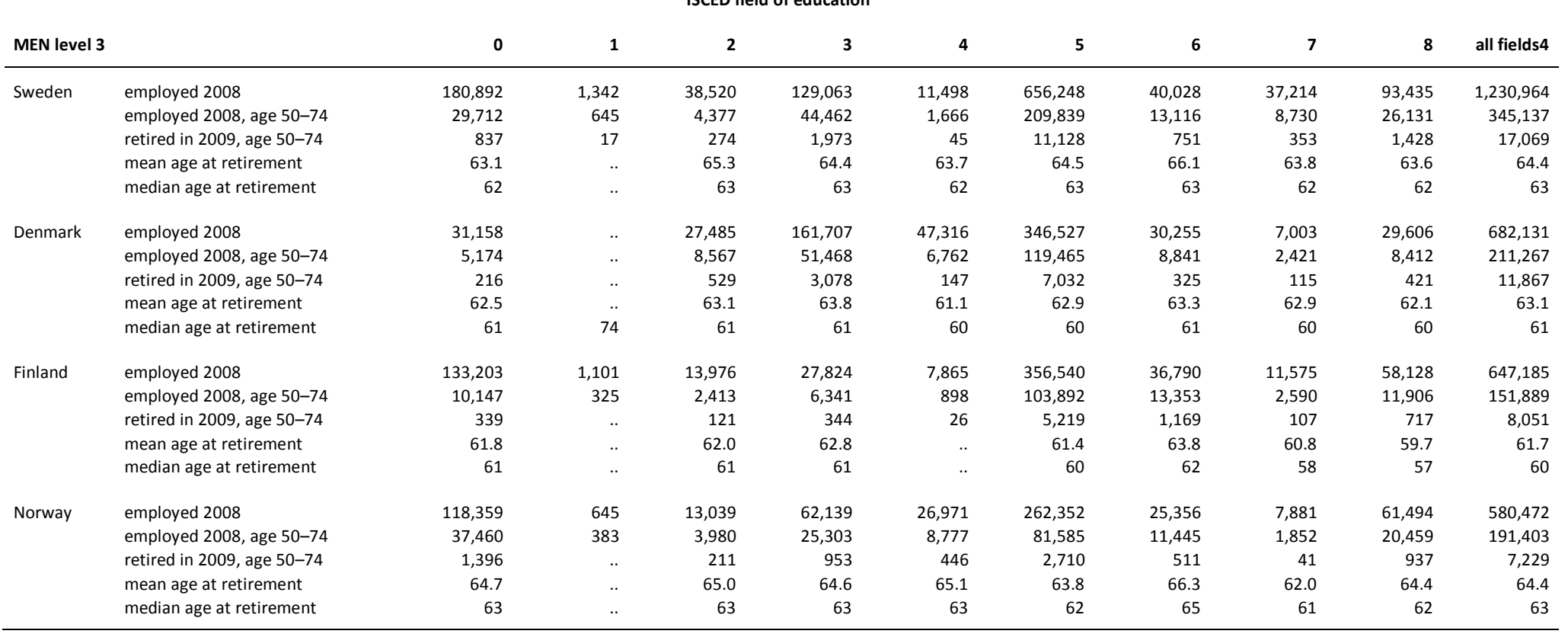

${ }^{1}$ includes persons with income from employment in 2008 who were registered residents on 31 December 2008 and 31 December 2009.

${ }^{2}$ A person is classified as having "retired in 2009" if they were registered residents in 2008 and 2009, had income from employment in 2008, had no income from employment in 2009, had pension income in 2009, and either 1) had no employment income but positive pension income in 2010 or 2) were not a registered resident in 2010.

${ }^{3}$ Includes level 3 and 4 for Denmark.

“"all fields" includes unknown level and "other". For Sweden, this includes 3,2 percent of persons with income from employment in 2008. For other countries, "unknown" and other comprise 0,1 percent or fewer of persons with income from employment in 2008. 
Table A5. Employed men 2008 ${ }^{1}$, employed women age 50-74 2008, retired in $2009^{2}$ among women age 50-74 in 2008, mean and median retirement age by ISCED 1997 field of education for women with highest ISCED level 3 education $^{3}$

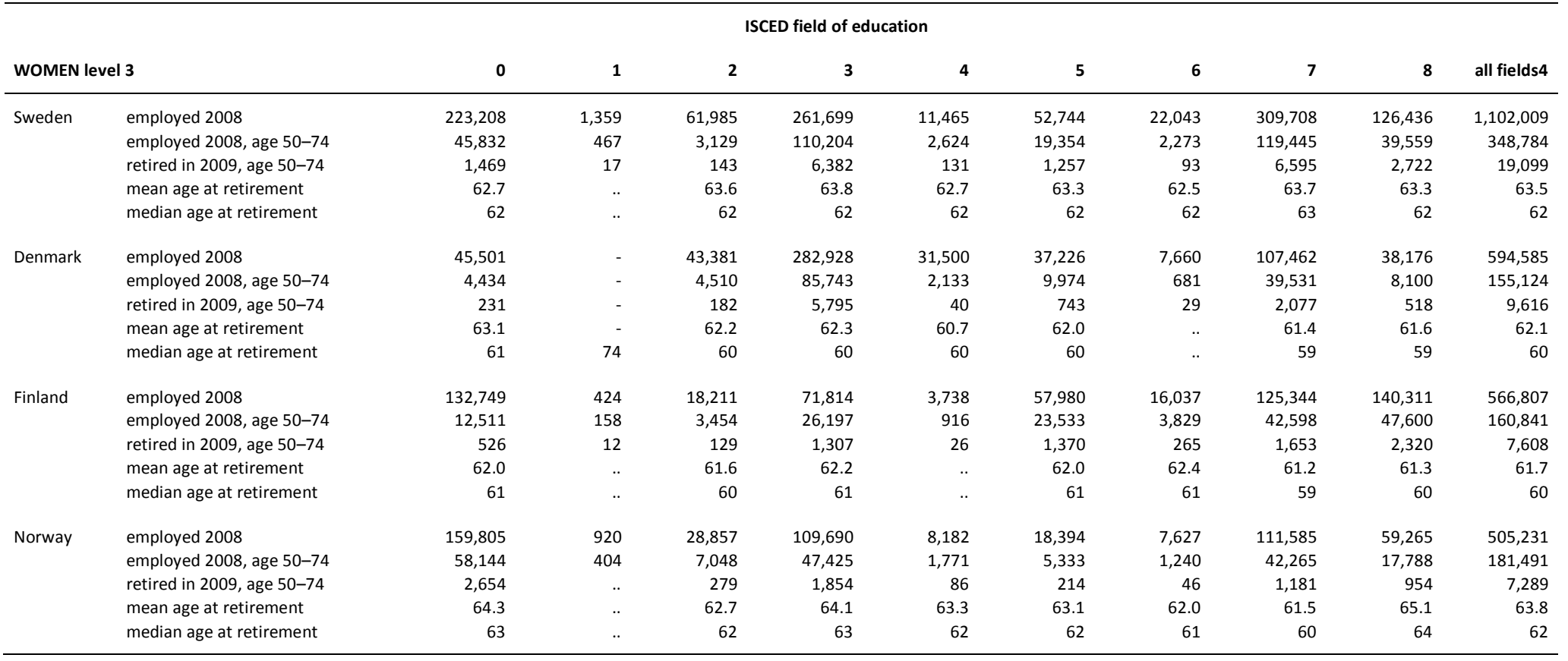

${ }^{1}$ includes persons with income from employment in 2008 who were registered residents on 31 December 2008 and 31 December 2009.

${ }^{2}$ A person is classified as having "retired in 2009" if they were registered residents in 2008 and 2009, had income from employment in 2008, had no income from employment in

2009, had pension income in 2009, and either 1) had no employment income but positive pension income in 2010 or 2) were not a registered resident in 2010.

${ }^{3}$ Includes level 3 and 4 for Denmark.

"“all fields" includes unknown level and "other". For Sweden, this includes 3.2 percent of persons with income from employment in 2008. For other countries, "unknown" and other

comprise 0.1 percent or fewer of persons with income from employment in 2008. 
Table A6. Employed persons $2008^{1}$, employed persons age 50-74 2008, retired in $2009^{2}$ among persons age 50-74 in 2008, mean and median retirement age by ISCED 1997 field of education for persons with highest ISCED level 3 education ${ }^{3}$

\begin{tabular}{|c|c|c|c|c|c|c|c|c|c|c|c|}
\hline & & & & & field of $\mathrm{ec}$ & & & & & & \\
\hline WOMEN & vel 3 & 0 & 1 & 2 & 3 & 4 & 5 & 6 & 7 & 8 & all fields4 \\
\hline Sweden & employed 2008 & 404,100 & 2,701 & 100,505 & 390,762 & 22,963 & 708,992 & 62,071 & 346,922 & 219,871 & $2,332,973$ \\
\hline & employed 2008 , age $50-74$ & 75,544 & 1,112 & 7,506 & 154,666 & 4,290 & 229,193 & 15,389 & 128,175 & 65,690 & 693,921 \\
\hline & retired in 2009 , age $50-74$ & 2,306 & 34 & 417 & 8,355 & 176 & 12,385 & 844 & 6,948 & 4,150 & 36,168 \\
\hline & mean age at retirement & 62.9 & 63.4 & 64.7 & 63.9 & 63.0 & 64.4 & 65.7 & 63.7 & 63.4 & 64.0 \\
\hline & median age at retirement & 62 & 62 & 63 & 63 & 62 & 63 & 63 & 63 & 62 & 63 \\
\hline Denmark & employed 2008 & 76,659 & - & 70,866 & 444,635 & 78,816 & 383,753 & 37,915 & 114,465 & 67,782 & $1,276,716$ \\
\hline & employed 2008, age 50-74 & 9,608 & - & 13,077 & 137,211 & 8,895 & 129,439 & 9,522 & 41,952 & 16,512 & 366,391 \\
\hline & retired in 2009 , age $50-74$ & 447 & - & 711 & 8,873 & 187 & 7,775 & 354 & 2,192 & 939 & 21,483 \\
\hline & mean age at retirement & 62.8 & - & 62.8 & 62.8 & 61.0 & 62.8 & 63.0 & 61.5 & 61.8 & 62.6 \\
\hline & median age at retirement & 61 & 74 & 60 & 60 & 60 & 60 & 60 & 59 & 60 & 60 \\
\hline Finland & employed 2008 & 265,952 & 1,525 & 32,187 & 99,638 & 11,603 & 414,520 & 52,827 & 136,919 & 198,439 & $1,213,992$ \\
\hline & employed 2008 , age $50-74$ & 22,658 & 483 & 5,867 & 32,538 & 1,814 & 127,425 & 17,182 & 45,188 & 59,506 & 312,730 \\
\hline & retired in 2009 , age $50-74$ & 865 & 20 & 250 & 1,651 & 52 & 6,589 & 1,434 & 1,760 & 3,037 & 15,659 \\
\hline & mean age at retirement & 61.9 & .. & 61.8 & 62.4 & 59.2 & 61.5 & 63.5 & 61.2 & 60.9 & 61.7 \\
\hline & median age at retirement & 61 & .. & 61 & 61 & 58 & 60 & 62 & 59 & 59 & 60 \\
\hline Norway & employed 2008 & 278,164 & 1,565 & 41,896 & 171,829 & 35,153 & 280,746 & 32,983 & 119,466 & 120,759 & $1,085,703$ \\
\hline & employed 2008, age 50-74 & 95,604 & 787 & 11,028 & 72,728 & 10,548 & 86,918 & 12,685 & 44,117 & 38,247 & 372,894 \\
\hline & retired in 2009 , age $50-74$ & 4,050 & 38 & 490 & 2,807 & 532 & 2,924 & 557 & 1,222 & 1,891 & 14,518 \\
\hline & mean age at retirement & 64.5 & 64.2 & 63.7 & 64.3 & 64.8 & 63.7 & 66.0 & 61.5 & 64.7 & 64.1 \\
\hline & median age at retirement & 63 & 64 & 62 & 63 & 63 & 62 & 65 & 60 & 63 & 62 \\
\hline
\end{tabular}

${ }^{1}$ includes persons with income from employment in 2008 who were registered residents on 31 December 2008 and 31 December 2009.

${ }^{2}$ A person is classified as having "retired in 2009" if they were registered residents in 2008 and 2009, had income from employment in 2008, had no income from employment in

2009, had pension income in 2009, and either 1) had no employment income but positive pension income in 2010 or 2) were not a registered resident in 2010.

${ }^{3}$ Includes level 3 and 4 for Denmark.

“"all fields" includes unknown level and "other". For Sweden, this includes 3.2 percent of persons with income from employment in 2008. For other countries, "unknown" and other comprise 0.1 percent or fewer of persons with income from employment in 2008. 
Table A7. Employed persons $2008^{1}$, employed persons age 50-74 2008, retired in 2009² among persons age 50-74 in 2008, mean and median retirement age by ISCED 1997 field of education for persons with level 4,5 , or 6 education

\begin{tabular}{|c|c|c|c|c|c|c|c|c|c|c|c|}
\hline \multicolumn{12}{|c|}{ ISCED field of education } \\
\hline \multicolumn{2}{|c|}{ MEN and WOMEN level 4,5 and 6} & 14 & 21 & 22 & 31 & 32 & 34 & 38 & 42 & 44 & 46 \\
\hline \multirow[t]{5}{*}{ Sweden } & employed 2008 & 335,912 & 40,999 & 79,742 & 111,799 & 28,863 & 218,114 & 44,520 & 17,781 & 16,216 & 21,987 \\
\hline & employed 2008, age 50-74 & 138,642 & 7,563 & 21,699 & 33,188 & 6,982 & 56,401 & 11,700 & 2,319 & 3,442 & 8,539 \\
\hline & retired in 2009, age 50-74 & 6,541 & 353 & 1,047 & 1,620 & 262 & 2,532 & 387 & 74 & 127 & 455 \\
\hline & mean age at retirement & 64.9 & 65.8 & 65.7 & 64.5 & 64.8 & 64.8 & 64.8 & 64.9 & 65.7 & 64.6 \\
\hline & median age at retirement & 63 & 64 & 63 & 63 & 63 & 63 & 63 & 63 & 64 & 63 \\
\hline \multirow[t]{5}{*}{ Denmark } & employed 2008 & 100,050 & 14,103 & 54,268 & 38,102 & 11,611 & 67,799 & 21,572 & 7,424 & 9,545 & 6,055 \\
\hline & employed 2008, age 50-74 & 44,802 & 2,371 & 14,491 & 9,505 & 4,752 & 12,670 & 5,723 & 1,981 & 2,747 & 1,682 \\
\hline & retired in 2009 , age $50-74$ & 2,819 & 58 & 469 & 222 & 192 & 439 & 205 & 0 & 90 & 39 \\
\hline & mean age at retirement & 62.8 & 64.5 & 65.3 & 64.2 & 62.9 & 64.4 & 66.0 & .. & 66.0 & 67.3 \\
\hline & median age at retirement & 60 & 63 & 65 & 63 & 61 & 62 & 65 & .. & 65 & 65 \\
\hline \multirow[t]{5}{*}{ Finland } & employed 2008 & 64,538 & 27,684 & 48,976 & 38,878 & 6,223 & 241,404 & 15,262 & 8,517 & 13,391 & 7,650 \\
\hline & employed 2008, age 50-74 & 22,451 & 4,433 & 16,922 & 14,488 & 1,551 & 79,445 & 6,078 & 2,559 & 4,776 & 3,693 \\
\hline & retired in 2009 , age $50-74$ & 1,193 & 148 & 891 & 651 & 77 & 3,039 & 252 & 110 & 209 & 220 \\
\hline & mean age at retirement & 63.4 & 64.5 & 63.8 & 63.9 & 63.2 & 62.3 & 64.1 & 64.2 & 64.1 & 62.6 \\
\hline & median age at retirement & 61 & 63 & 62 & 62 & 61 & 61 & 62 & 62 & 62 & 60 \\
\hline \multirow[t]{5}{*}{ Norway } & employed 2008 & 164,291 & 17,263 & 46,671 & 80,625 & 11,081 & 110,355 & 22,445 & 7,134 & 9,589 & 1,893 \\
\hline & employed 2008, age 50-74 & 62,374 & 3,386 & 16,087 & 16,695 & 2,169 & 27,410 & 5,242 & 1,645 & 3,067 & 645 \\
\hline & retired in 2009, age 50-74 & 1,922 & 70 & 425 & 334 & 48 & 657 & 108 & 25 & 83 & 27 \\
\hline & mean age at retirement & 64.5 & 63.6 & 65.5 & 64.4 & 64.1 & 64.4 & 64.3 & .. & 65.4 & .. \\
\hline & median age at retirement & 63 & 63 & 64 & 63 & 64 & 63 & 63 & .. & 63 & .. \\
\hline
\end{tabular}

${ }^{1}$ includes persons with income from employment in 2008 who were registered residents on 31 December 2008 and 31 December 2009.

'A person is classified as having "retired in 2009" if they were registered residents in 2008 and 2009, had income from employment in 2008, had no income from employment in

2009 , had pension income in 2009, and either 1) had no employment income but positive pension income in 2010 or 2) were not a registered resident in 2010.

Includes only levels 5A and 6 for Denmark. 
Table A7 (cont.). Employed persons 2008 ${ }^{1}$, employed persons age 50-74 2008, retired in 2009 ${ }^{2}$ among persons age 50-74 in 2008, mean and median retirement age by ISCED 1997 field of education for persons with level 4,5 , or 6 education

\begin{tabular}{|c|c|c|c|c|c|c|c|c|c|c|c|}
\hline & & & & ISCED & f educati & & & & & & \\
\hline MEN and & NOMEN level 4,5 and 6 & 48 & 52 & 54 & 58 & 62 & 64 & 72 & 76 & 81 & 84 \\
\hline Sweden & employed 2008 & 50,946 & 273,341 & 9,630 & 55,674 & 17,951 & 3,197 & 267,787 & 74,729 & 16,378 & 8,393 \\
\hline & employed 2008, age 50-74 & 7,974 & 58,749 & 2,685 & 13,159 & 6,412 & 1,019 & 103,182 & 26,273 & 1,101 & 2,667 \\
\hline & retired in 2009 , age 50-74 & 239 & 1,674 & 93 & 397 & 248 & 25 & 3,550 & 908 & 22 & 190 \\
\hline & mean age at retirement & 63.1 & 64.2 & 64.6 & 65.1 & 66.5 & .. & 64.7 & 64.5 & .. & 64.8 \\
\hline & median age at retirement & 61 & 63 & 63 & 63 & 64 & .. & 63 & 63 & .. & 63 \\
\hline Denmark & employed 2008 & 7,402 & 46,710 & 1,524 & 42,743 & 4,968 & 3,556 & 123,535 & 119,644 & 1,867 & 2,686 \\
\hline & employed 2008, age 50-74 & 688 & 15,937 & 341 & 13,541 & 1,571 & 1,131 & 44,440 & 41,655 & 402 & 1,014 \\
\hline & retired in 2009 , age $50-74$ & 0 & 725 & 0 & 546 & 68 & 37 & 1,707 & 1,819 & 0 & 54 \\
\hline & mean age at retirement & .. & 65.4 & .. & 65.2 & 65.6 & 66.8 & 64.0 & 61.4 & .. & 65.5 \\
\hline & median age at retirement & .. & 64 & .. & 63 & 63 & 65 & 63 & 59 & .. & 64 \\
\hline Finland & employed 2008 & 26,649 & 156,293 & 16,170 & 43,132 & 23,894 & 1,366 & 139,513 & 24,974 & 34,831 & 2,279 \\
\hline & employed 2008, age 50-74 & 3,707 & 47,223 & 5,477 & 19,711 & 8,452 & 434 & 45,184 & 4,628 & 5,135 & 1,094 \\
\hline & retired in 2009 , age $50-74$ & 71 & 1,935 & 309 & 874 & 525 & 18 & 1,836 & 136 & 125 & 100 \\
\hline & mean age at retirement & 60.0 & 63.4 & 63.4 & 64.4 & 65.2 & .. & 62.9 & 62.4 & 61.4 & 62.5 \\
\hline & median age at retirement & 58 & 61 & 61 & 62 & 63 & .. & 61 & 61 & 61 & 61 \\
\hline Norway & employed 2008 & 24,153 & 84,014 & 4,039 & 32,942 & 10,167 & 2,286 & 153,094 & 23,856 & 12,798 & 7,060 \\
\hline & employed 2008, age 50-74 & 2,335 & 28,330 & 916 & 12,838 & 2,554 & 678 & 44,396 & 6,244 & 1,220 & 3,156 \\
\hline & retired in 2009 , age $50-74$ & 22 & 871 & 12 & 250 & 58 & 13 & 1,172 & 124 & 22 & 160 \\
\hline & mean age at retirement & .. & 65.4 & .. & 65.5 & 66.9 & .. & 64.8 & 62.6 & .. & 65.4 \\
\hline & median age at retirement & .. & 64 & .. & 64 & 66 & .. & 63 & 61 & .. & 63 \\
\hline
\end{tabular}

${ }^{1}$ includes persons with income from employment in 2008 who were registered residents on 31 December 2008 and 31 December 2009.

'A person is classified as having "retired in 2009" if they were registered residents in 2008 and 2009, had income from employment in 2008, had no income from employment in

2009 , had pension income in 2009, and either 1) had no employment income but positive pension income in 2010 or 2) were not a registered resident in 2010.

Includes only levels 5A and 6 for Denmark. 
Table A7 (cont.). Employed persons 2008 ${ }^{1}$, employed persons age 50-74 2008, retired in 2009 ${ }^{2}$ among persons age 50-74 in 2008, mean and median retirement age by ISCED 1997 field of education for persons with level 4, 5, or 6 education

\begin{tabular}{|c|c|c|c|}
\hline \multicolumn{2}{|c|}{ MEN and WOMEN level 4,5 and 6} & \multirow{2}{*}{$\begin{array}{r}48 \\
3,460\end{array}$} & \multirow{2}{*}{$\frac{\mathbf{5 2}}{41,122}$} \\
\hline Sweden & employed 2008 & & \\
\hline & employed 2008 , age $50-74$ & 815 & 17,487 \\
\hline & retired in 2009 , age 50-74 & 26 & 1,034 \\
\hline & mean age at retirement & .. & 64.7 \\
\hline & median age at retirement & .. & 63 \\
\hline \multirow[t]{5}{*}{ Denmark } & employed 2008 & 428 & 4,600 \\
\hline & employed 2008 , age $50-74$ & 40 & 1,146 \\
\hline & retired in 2009 , age 50-74 & 0 & 71 \\
\hline & mean age at retirement & .. & 63.4 \\
\hline & median age at retirement & .. & 61 \\
\hline \multirow[t]{5}{*}{ Finland } & employed 2008 & 2,406 & 13,245 \\
\hline & employed 2008 , age $50-74$ & 407 & 4,143 \\
\hline & retired in 2009 , age $50-74$ & 10 & 383 \\
\hline & mean age at retirement & .. & 60.8 \\
\hline & median age at retirement & .. & 59 \\
\hline \multirow[t]{5}{*}{ Norway } & employed 2008 & 2,713 & 21,398 \\
\hline & employed 2008, age $50-74$ & 351 & 3,895 \\
\hline & retired in 2009, age 50-74 & .. & 116 \\
\hline & mean age at retirement & .. & 63.1 \\
\hline & median age at retirement & .. & 62 \\
\hline
\end{tabular}

${ }^{1}$ includes persons with income from employment in 2008 who were registered residents on 31 December 2008 and 31 December 2009.

"A person is classified as having "retired in 2009" if they were registered residents in 2008 and 2009, had income from employment in 2008, had no income from employment in

2009 , had pension income in 2009, and either 1) had no employment income but positive pension income in 2010 or 2) were not a registered resident in 2010.

${ }^{3}$ Includes only levels 5 A and 6 for Denmark. 
ISCED field of education

\begin{tabular}{|c|c|c|c|c|c|c|c|c|c|c|c|}
\hline \multicolumn{2}{|c|}{ MEN and WOMEN level 4,5 and 6} & \multirow{2}{*}{$\begin{array}{r}48 \\
50,946\end{array}$} & \multirow{2}{*}{$\begin{array}{r}\mathbf{5 2} \\
273,341\end{array}$} & \multirow{2}{*}{$\begin{array}{r}54 \\
9,630\end{array}$} & \multirow{2}{*}{$\begin{array}{r}58 \\
55,674\end{array}$} & \multirow{2}{*}{$\begin{array}{r}\mathbf{6 2} \\
17,951\end{array}$} & \multirow{2}{*}{$\begin{array}{r}64 \\
3,197\end{array}$} & \multirow{2}{*}{$\begin{array}{r}\mathbf{7 2} \\
267,787\end{array}$} & \multirow{2}{*}{$\begin{array}{r}76 \\
74,729\end{array}$} & \multirow{2}{*}{$\begin{array}{r}\mathbf{8 1} \\
16,378\end{array}$} & \multirow{2}{*}{$\begin{array}{r}84 \\
8,393\end{array}$} \\
\hline Sweden & employed 2008 & & & & & & & & & & \\
\hline & employed 2008, age 50-74 & 7,974 & 58,749 & 2,685 & 13,159 & 6,412 & 1,019 & 103,182 & 26,273 & 1,101 & 2,667 \\
\hline & retired in 2009 , age $50-74$ & 239 & 1,674 & 93 & 397 & 248 & 25 & 3,550 & 908 & 22 & 190 \\
\hline & mean age at retirement & 63.1 & 64.2 & 64.6 & 65.1 & 66.5 & .. & 64.7 & 64.5 & & 64.8 \\
\hline & median age at retirement & 61 & 63 & 63 & 63 & 64 & .. & 63 & 63 & & 63 \\
\hline \multirow[t]{5}{*}{ Denmark } & employed 2008 & 7,402 & 46,710 & 1,524 & 42,743 & 4,968 & 3,556 & 123,535 & 119,644 & 1,867 & 2,686 \\
\hline & employed 2008, age 50-74 & 688 & 15,937 & 341 & 13,541 & 1,571 & 1,131 & 44,440 & 41,655 & 402 & 1,014 \\
\hline & retired in 2009, age 50-74 & 0 & 725 & 0 & 546 & 68 & 37 & 1,707 & 1,819 & 0 & 54 \\
\hline & mean age at retirement & & 65.4 &. & 65.2 & 65.6 & 66.8 & 64.0 & 61.4 & & 65.5 \\
\hline & median age at retirement & .. & 64 & .. & 63 & 63 & 65 & 63 & 59 & & 64 \\
\hline \multirow[t]{5}{*}{ Finland } & employed 2008 & 26,649 & 156,293 & 16,170 & 43,132 & 23,894 & 1,366 & 139,513 & 24,974 & 34,831 & 2,279 \\
\hline & employed 2008, age 50-74 & 3,707 & 47,223 & 5,477 & 19,711 & 8,452 & 434 & 45,184 & 4,628 & 5,135 & 1,094 \\
\hline & retired in 2009 , age $50-74$ & 71 & 1,935 & 309 & 874 & 525 & 18 & 1,836 & 136 & 125 & 100 \\
\hline & mean age at retirement & 60.0 & 63.4 & 63.4 & 64.4 & 65.2 & .. & 62.9 & 62.4 & 61.4 & 62.5 \\
\hline & median age at retirement & 58 & 61 & 61 & 62 & 63 & .. & 61 & 61 & 61 & 61 \\
\hline \multirow[t]{5}{*}{ Norway } & employed 2008 & 24,153 & 84,014 & 4,039 & 32,942 & 10,167 & 2,286 & 153,094 & 23,856 & 12,798 & 7,060 \\
\hline & employed 2008, age 50-74 & 2,335 & 28,330 & 916 & 12,838 & 2,554 & 678 & 44,396 & 6,244 & 1,220 & 3,156 \\
\hline & retired in 2009, age 50-74 & 22 & 871 & 12 & 250 & 58 & 13 & 1,172 & 124 & 22 & 160 \\
\hline & mean age at retirement & 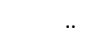 & 65.4 & .. & 65.5 & 66.9 & .. & 64.8 & 62.6 & 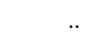 & 65.4 \\
\hline & median age at retirement & .. & 64 & .. & 64 & 66 & .. & 63 & 61 & .. & 63 \\
\hline
\end{tabular}




\section{Appendix 2 - ISCED Levels and Fields of education}

The ISCED 1997 levels and fields shown here are the ones used in this report. For level and field and the 1-digit level, they cover all levels in the ISCED classification system. At the 2-digit level, there are additional fields not shown and not used in the report. These fields include 00 (general programs), 20 (Humanities and arts at the post-secondary and tertiary in some countries), 50 (certain programmes within engineering, manufacturing and construction) and 29, 39, 49, 59, 69 and 79 (unknown narrow fields within the broad field).

The proportion of the relevant population with fields not shown is different in different countries. It is highest in Norway, at 7,8 percent of employed tertiary-educated, and lower in Sweden, Denmark and Finland, at two percent or less. Calculations for ISCED levels include all persons at each level, including those with fields not shown here or used in the report.

ISCED 1997 levels of education

\begin{tabular}{ll}
0 & Pre-primary education \\
1 & Primary education, first stage of basic education \\
2 & Lower secondary education \\
3 & Upper) secondary education \\
4 & Post-secondary non tertiary education. \\
$5 b$ & First stage of tertiary education (not leading directly to an advanced research qualification). \\
$5 a$ & First stage of tertiary education (not leading directly to an advanced research qualification) \\
6 & Second stage of tertiary education (leading to an advanced research qualification) \\
\hline & \\
ISCED 1997 fields of education, 1-digit level \\
\hline 0 & General programmes \\
1 & Education \\
2 & Humanities and Arts \\
3 & Social sciences, business and law \\
4 & Science \\
5 & Engineering, manufacturing and construction \\
6 & Agriculture \\
7 & Health and welfare \\
8 & Services \\
99 & not known or specified \\
\hline
\end{tabular}


ISCED 1997 fields of education, 2-digit level

\begin{tabular}{ll}
14 & Teacher training and education \\
21 & Arts \\
22 & Humanities \\
31 & Social and behavioural science \\
32 & Journalism and information \\
34 & Business and administration \\
38 & Law \\
42 & Life sciences \\
44 & Physical sciences \\
46 & Mathematics and statistics \\
48 & Computing \\
52 & Engineering and engineering trades \\
54 & Manufacturing and processing \\
58 & Architecture and building \\
62 & Agriculture, forestry and fish \\
64 & Veterinary \\
72 & Health \\
76 & Social services \\
81 & Personal services \\
84 & Transport services \\
85 & Environmental protection \\
86 & Security services \\
\hline
\end{tabular}


Nordic Council of Ministers

Ved Stranden 18

DK-1061 Copenhagen K

www.norden.org

\section{Age at retirement by educational}

\section{background in Nordic country}

The labour force in Nordic countries will change over the next few years. Absent additional pension policy changes, a majority of working persons age 50 and older will retire by 2020 .

Average retirement age varies by educational level, field of study and country. Persons with a post-secondary education tend to retire older than persons with a secondary education. Denmark and Finland have lower actual retirement ages than Sweden or Norway, roughly a year and a half lower for men and two years lower for women.

Because of rising educational levels, actual retirement age will likely rise even absent additional policy changes. Because retirement lower in Denmark and Finland than in Sweden or Norway, there appears to be more 'room' in the former countries to influence retirement age via policy. There is also more 'room' to close the gender gap in average retirement age in Denmark than in other countries.

The decision to retire is affected by many factors, one of which is educational background. This report focuses on the education dimension, showing how retirement age has varied in recent years and how such changes will affect the size of the labour force in the near future.

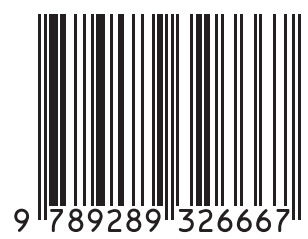

